Prepared in cooperation with the National Park Service

\title{
Distribution of Trace Metals at Hopewell Furnace National Historic Site, Berks and Chester Counties, Pennsylvania
}

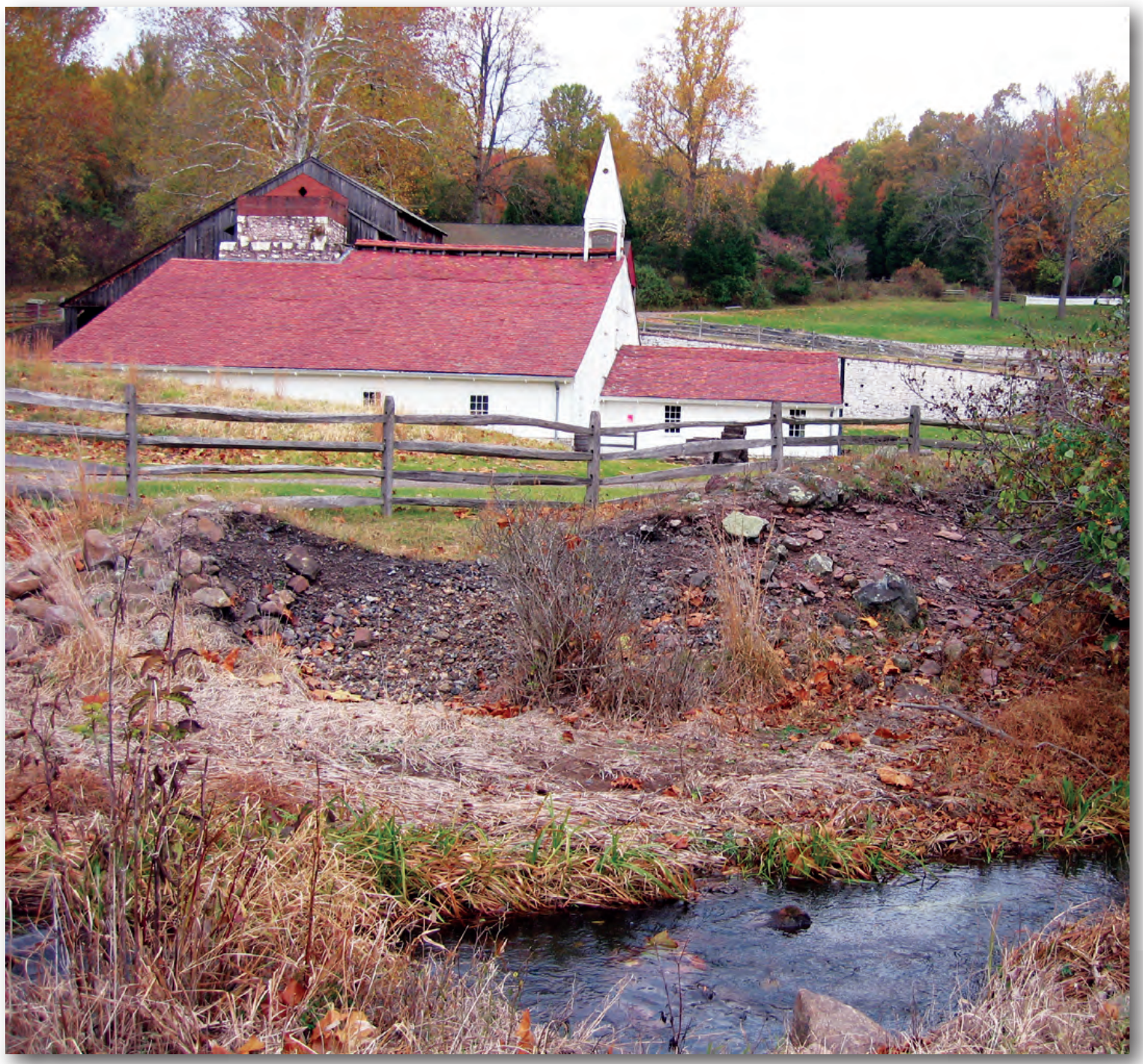

Scientific Investigations Report 2011-5014 
Cover. Photograph showing the cast house at Hopewell Furnace National Historic site, Pennsylvania. The cast house encloses the furnace. The stone stack of the furnace is visible on the left side of the cast house. In the foreground, part of the furnace slag pile is exposed and makes up the left bank of French Creek. 


\section{Distribution of Trace Metals at Hopewell Furnace National Historic Site, Berks and Chester Counties, Pennsylvania}

By Ronald A. Sloto and Andrew G. Reif

Prepared in cooperation with the National Park Service

Scientific Investigations Report 2011-5014 


\title{
U.S. Department of the Interior \\ KEN SALAZAR, Secretary \\ U.S. Geological Survey \\ Marcia K. McNutt, Director
}

\author{
U.S. Geological Survey, Reston, Virginia: 2011
}

For more information on the USGS - the Federal source for science about the Earth, its natural and living resources, natural hazards, and the environment, visit http://www.usgs.gov or call 1-888-ASK-USGS.

For an overview of USGS information products, including maps, imagery, and publications, visit http://www.usgs.gov/pubprod

To order this and other USGS information products, visit http://store.usgs.gov

Any use of trade, product, or firm names is for descriptive purposes only and does not imply endorsement by the U.S. Government.

Although this report is in the public domain, permission must be secured from the individual copyright owners to reproduce any copyrighted materials contained within this report.

Suggested citation:

Sloto, R.A., and Reif, A.G., 2011, Distribution of trace metals at Hopewell Furnace National Historic Site, Berks and Chester Counties, Pennsylvania: U.S. Geological Survey Scientific Investigations Report 2011-5014, 79 p. 


\section{Contents}

Abstract
Introduction
Purpose and Scope




\section{Figures}

1. Map showing location of Hopewell Furnace National Historic Site, Pennsylvania..........2

2. Map showing locations of sampled slag piles at Hopewell Furnace National Historic Site, Pennsylvania

3. Map showing locations of selected iron mines near Hopewell Furnace National Historic Site, Pennsylvania

4. Cross-section diagram of a charcoal iron furnace ..........................................................

5. Flow chart showing potential pathways for migration of metals at Hopewell Furnace National Historic Site, Pennsylvania

6. Map showing locations of slag samples collected at Hopewell Furnace National Historic Site, Pennsylvania ...

7. Map showing locations of soil samples collected at Hopewell Furnace National Historic Site, Pennsylvania

8. Graph showing vertical profile of arsenic, chromium, copper, and lead concentrations in soil at soil sampling site SOIL-5, Hopewell Furnace

National Historic Site, Pennsylvania

9. Photographs showing cast iron artifacts in the Hopewell National Historic Site museum sampled for trace-metal concentrations using portable X-ray fluorescence spectroscopy

10. Map showing stream sampling locations at Hopewell Furnace National Historic Site, Pennsylvania

11. Map showing drainage basin upstream from site HF-1, Hopewell Furnace National Historic Site, Pennsylvania 


\section{Tables}

1. Concentrations of selected trace metals in ore samples from iron mines in southeastern Pennsylvania.

2. Concentrations of selected trace metals in ore samples from the Hopewell and Jones mines, southeastern Pennsylvania.....

3. Concentrations of selected trace metals in slag samples, Hopewell Furnace National Historic Site, Pennsylvania

4. Mean concentration and range for selected trace metals in soil in the eastern United States.

5. Concentrations of selected trace metals in soil samples analyzed by inductively coupled plasma-atomic emission spectrometry and inductively coupled plasma-mass spectrometry, Hopewell Furnace National Historic Site, Pennsylvania .

6. Pennsylvania Department of Environmental Protection statewide health standards for soil

7. Concentration of selected trace metals in soil samples analyzed by X-ray fluorescence spectroscopy, Hopewell Furnace National Historic Site, Pennsylvania.

8. Comparison of concentrations of selected trace metals in soils analyzed by inductively coupled plasma-atomic emission spectrometry and X-ray fluorescence spectroscopy, Hopewell Furnace National Historic Site, Pennsylvania

9. Mean concentrations of selected trace metals analyzed by X-ray fluorescence spectroscopy in cast iron artifacts in the Hopewell Furnace National Historic Site museum, Pennsylvania

10. Chemical analysis results for selected constituents in groundwater, Hopewell Furnace National Historic Site, Pennsylvania

11. U.S. Environmental Protection Agency maximum contaminant, secondary contaminant, and action levels for constituents in drinking water

12. Chemical analysis results and estimated loads and yields for selected trace metals in surface-water base-flow samples, Hopewell Furnace National Historic Site, Pennsylvania

13. Comparison of published criteria maximum and continuous concentrations to measured maximum concentrations of selected trace metals in stream sediment at Hopewell Furnace National Historic Site, Pennsylvania

14. Chemical analysis results for trace metals in streambed sediment samples, Hopewell Furnace National Historic Site, Pennsylvania

15. Comparison of published probable effects concentrations and measured maximum concentrations of selected trace metals in streambed sediment at Hopewell Furnace National Historic Site, Pennsylvania

16. Biometrics for benthic macroinvertebrates sampled at Hopewell Furnace National Historic Site, Pennsylvania

17. Results of habitat survey conducted at Hopewell Furnace National Historic Site, Pennsylvania

18. Summary statistics for concentrations of selected trace metals in ore, slag, cast iron artifacts, soil, groundwater, stream baseflow, and streambed sediment, Hopewell Furnace National Historic Site, Pennsylvania 


\section{Conversion Factors}

\begin{tabular}{|c|c|c|}
\hline Multiply & By & To obtain \\
\hline \multicolumn{3}{|c|}{ Length } \\
\hline inch (in) & 2.54 & centimeter $(\mathrm{cm})$ \\
\hline foot $(\mathrm{ft})$ & 0.3048 & meter $(\mathrm{m})$ \\
\hline mile (mi) & 1.609 & kilometer (km) \\
\hline \multicolumn{3}{|c|}{ Area } \\
\hline acre & 4,047 & square meter $\left(\mathrm{m}^{2}\right)$ \\
\hline square mile $\left(\mathrm{mi}^{2}\right)$ & 2.590 & square kilometer $\left(\mathrm{km}^{2}\right)$ \\
\hline \multicolumn{3}{|c|}{ Flow rate } \\
\hline cubic foot per second $\left(\mathrm{ft}^{3} / \mathrm{s}\right)$ & 0.02832 & cubic meter per second $\left(\mathrm{m}^{3} / \mathrm{s}\right)$ \\
\hline
\end{tabular}

SI to Inch/Pound

\begin{tabular}{lll}
\hline \multicolumn{1}{c}{ Multiply } & \multicolumn{1}{c}{ By } & \multicolumn{1}{c}{ To obtain } \\
\hline & \multicolumn{1}{c}{ Length } & \\
\hline centimeter $(\mathrm{cm})$ & 0.3937 & inch (in) \\
millimeter $(\mathrm{mm})$ & 0.03937 & inch (in) \\
meter $(\mathrm{m})$ & 3.281 & foot (ft) \\
\hline \multicolumn{3}{c}{ Volume } \\
\hline liter $(\mathrm{L})$ & 0.2642 & gallon (gal) \\
\hline \multicolumn{2}{c}{ Mass } & \\
\hline gram $(\mathrm{g})$ & 0.03527 & ounce, avoirdupois $(\mathrm{oz})$ \\
kilogram $(\mathrm{kg})$ & 2.205 & pound avoirdupois $(\mathrm{lb})$ \\
\hline
\end{tabular}

Temperature in degrees Celsius $\left({ }^{\circ} \mathrm{C}\right)$ may be converted to degrees Fahrenheit $\left({ }^{\circ} \mathrm{F}\right)$ as follows:

${ }^{\circ} \mathrm{F}=\left(1.8 x^{\circ} \mathrm{C}\right)+32$

Temperature in degrees Fahrenheit $\left({ }^{\circ} \mathrm{F}\right)$ may be converted to degrees Celsius $\left({ }^{\circ} \mathrm{C}\right)$ as follows:

${ }^{\circ} \mathrm{C}=\left({ }^{\circ} \mathrm{F}-32\right) / 1.8$

Vertical coordinate information is referenced to the North American Vertical Datum of 1988 (NAVD 88).

Horizontal coordinate information is referenced to the North American Datum of 1983 (NAD 83).

Specific conductance is given in microsiemens per centimeter at 25 degrees Celsius $(\mu \mathrm{S} / \mathrm{cm}$ at $\left.25^{\circ} \mathrm{C}\right)$.

Concentrations of chemical constituents in water are given either in milligrams per liter (mg/L) or micrograms per liter $(\mu \mathrm{g} / \mathrm{L})$. 


\title{
Distribution of Trace Metals at Hopewell Furnace National Historic Site, Berks and Chester Counties, Pennsylvania
}

\author{
By Ronald A. Sloto and Andrew G. Reif
}

\section{Abstract}

Hopewell Furnace, located approximately 50 miles northwest of Philadelphia, was a cold-blast, charcoal iron furnace that operated for 113 years (1771 to 1883 ). The purpose of this study by the U.S. Geological Survey, in cooperation with the National Park Service, was to determine the distribution of trace metals released to the environment from an historical iron smelter at Hopewell Furnace National Historic Site (NHS). Hopewell Furnace used iron ore from local mines that contained abundant magnetite and accessory sulfide minerals enriched in arsenic, cobalt, copper, and other metals. Ore, slag, cast iron furnace products, soil, groundwater, stream base flow, streambed sediment, and benthic macroinvertebrates were sampled for this study. Soil samples analyzed in the laboratory had concentrations of trace metals low enough to meet Pennsylvania Department of Environmental Protection standards for non-residential use. Groundwater samples from the supply well met U.S. Environmental Protection Agency drinkingwater regulations. Concentrations of metals in surface-water base flow at the five stream sampling sites were below continuous concentration criteria for protection of aquatic organisms. Concentrations of metals in sediment at the five stream sites were below probable effects level guidelines for protection of aquatic organisms except for copper at site HF-3.

Arsenic, copper, lead, zinc, and possibly cobalt were incorporated into the cast iron produced by Hopewell Furnace. Manganese was concentrated in slag along with iron, nickel, and zinc. The soil near the furnace has elevated concentrations of chromium, copper, iron, lead, and zinc compared to background soil concentrations. Concentrations of toxic elements were not present at concentrations of concern in water, soil, or stream sediments, despite being elevated in ore, slag, and cast iron furnace products.

The base-flow surface-water samples indicated good overall quality. The five sampled sites generally had low concentrations of nutrients and major ions but had elevated concentrations of iron, manganese, and strontium when compared to sites sampled in adjacent watersheds. The background site on Baptism Creek generally had the lowest concentrations and yields of constituents. Low concentrations of nutrients and major ions at all five sites indicate that measured concentrations can be attributed to general land use and geology and not to point sources.

Streambed-sediment sampling results indicated higher concentrations of all metals except nickel at sites on French Creek compared to the background site on Baptism Creek. Concentrations of aluminum, cadmium, and nickel were highest in sediment from the sampling site upstream from Hopewell Furnace. The highest concentrations of arsenic, boron, cobalt, copper, iron, lead, manganese, mercury, and zinc were detected at the site just below Hopewell Furnace, which indicates that the source of these metals may be in Hopewell Furnace NHS.

The invertebrate community at the background site on Baptism Creek was dominated by pollution sensitive taxa indicating a healthy, diverse benthic-macroinvertebrate community. Benthic-macroinvertebrate communities at sampling sites on French Creek indicated disturbed communities when compared to the background site on Baptism Creek and that the overall stream quality immediately above and below Hopewell Furnace NHS is degraded. The benthic-macroinvertebrate communities were dominated by pollution-tolerant taxa, and taxa were less diverse than at the background site.

Habitat conditions at the upstream site on French Creek were good but were degraded at downstream sites on French Creek. The major habitat issues at these sites were related to a lack of stable substrate, erosion, and deposition. Water quality and streambed-sediment quality do not indicate that the degraded benthic-macroinvertebrate communities are the result of poor water quality. Habitat conditions (erosion and sedimentation) and physical alterations (water temperature) from the outfall of Hopewell Lake are the most likely causes of the impaired communities.

\section{Introduction}

Hopewell Furnace National Historic Site (NHS) is one of the finest examples of a rural American 19th-century iron plantation. The buildings include a cold-blast, charcoal-fired 
iron furnace, the ironmaster's mansion, and auxiliary structures. Hopewell Furnace began making iron before the Revolutionary War and was in operation for 113 years (1771-1883). The 848-acre site is representative of the hundreds of iron plantations that flourished in the 18th and early 19th centuries.

Hopewell Furnace NHS, located approximately $50 \mathrm{mi}$ northwest of Philadelphia, straddles the Berks-Chester County border in southeastern Pennsylvania (fig. 1). It is adjacent to the 1,800-acre Pennsylvania State Game Lands Number 43 and the popular 7,339-acre French Creek State Park, which offers hunting, fishing, boating, hiking, and camping. Hopewell Furnace NHS and the surrounding French Creek State Park host almost 1 million visitors every year (Hopewell Furnace National Historic Site, 2007).

French Creek flows through the heart of Hopewell Furnace NHS, which is near its headwaters. The Commonwealth of Pennsylvania designated French Creek as a State Wild and Scenic River in 1982 because of its outstanding natural and scenic values. It also bears the Commonwealth's designations of High Quality Waters-Cold Water Fishery and Exceptional Value Stream. French Creek is listed in the National Park Service (NPS) Nationwide Rivers Inventory (NRI), a listing of free-flowing river segments in the United States that possess one or more "outstandingly remarkable" natural or cultural values judged to be of more than local or regional significance (National Park Service, 2009). Under a 1979 Presidential directive, all Federal agencies must seek to avoid or mitigate actions that would adversely affect NRI segments. Outstandingly Remarkable Values listed by the NPS for French Creek include (1) hydrologic (northernmost, least developed, freeflowing river within the Piedmont), (2) historic (river-related National Historic Register sites and an Historic District within the corridor), and (3) geologic (area includes the unique Falls of French Creek). The Hopewell Furnace slag piles are close to and, in some locations, make up the banks of French Creek (fig. 2).

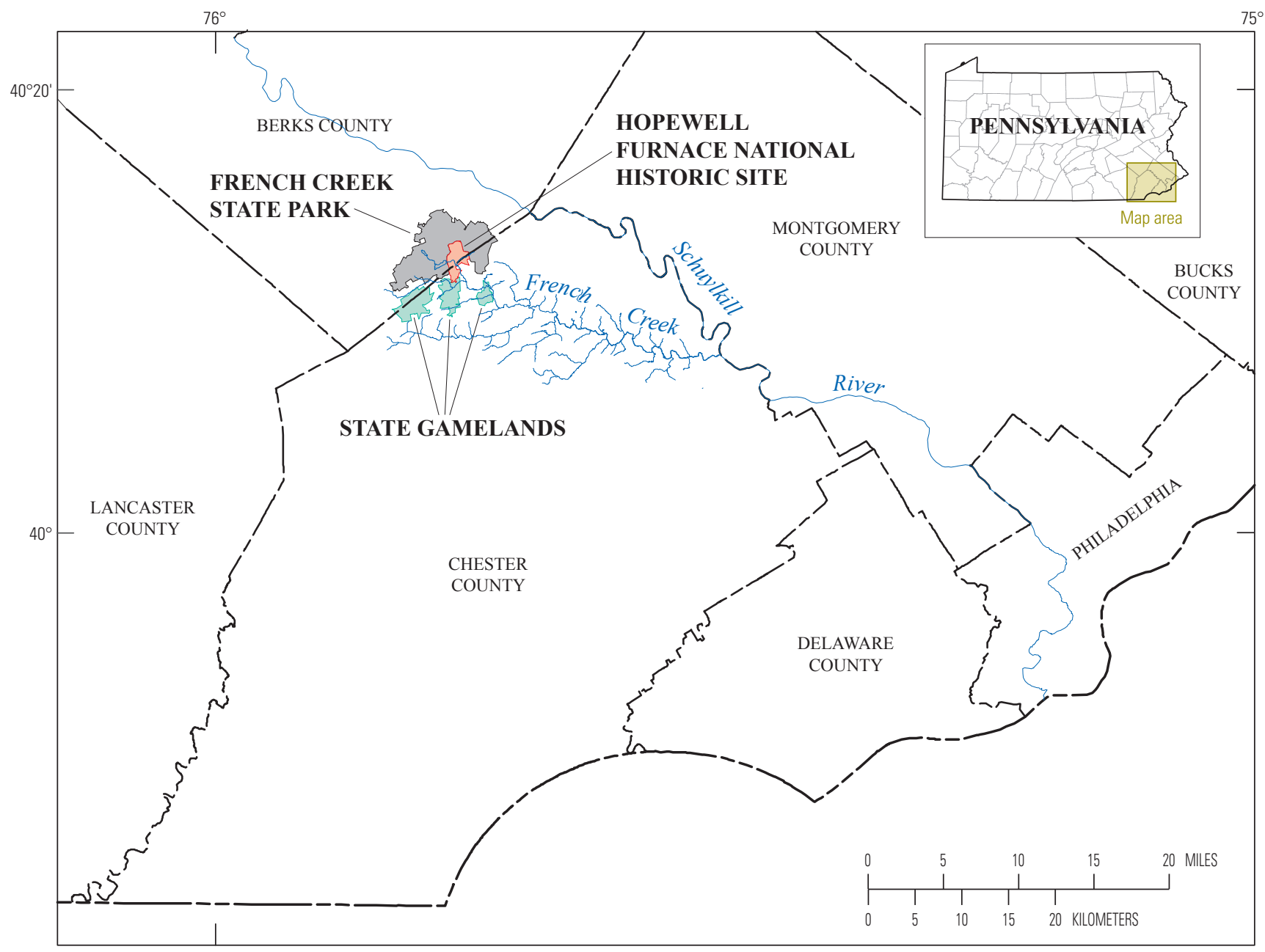

Base from U.S. Geological Survey digital data, 1972

1:2,000,000 Albers Equal-AreaConic Projection

Standard parallels $29^{\circ} 30^{\prime} \mathrm{N}$, cental meridian $75^{\circ} 00^{\prime} \mathrm{W}$

Figure 1. Location of Hopewell Furnace National Historic Site, Pennsylvania. 


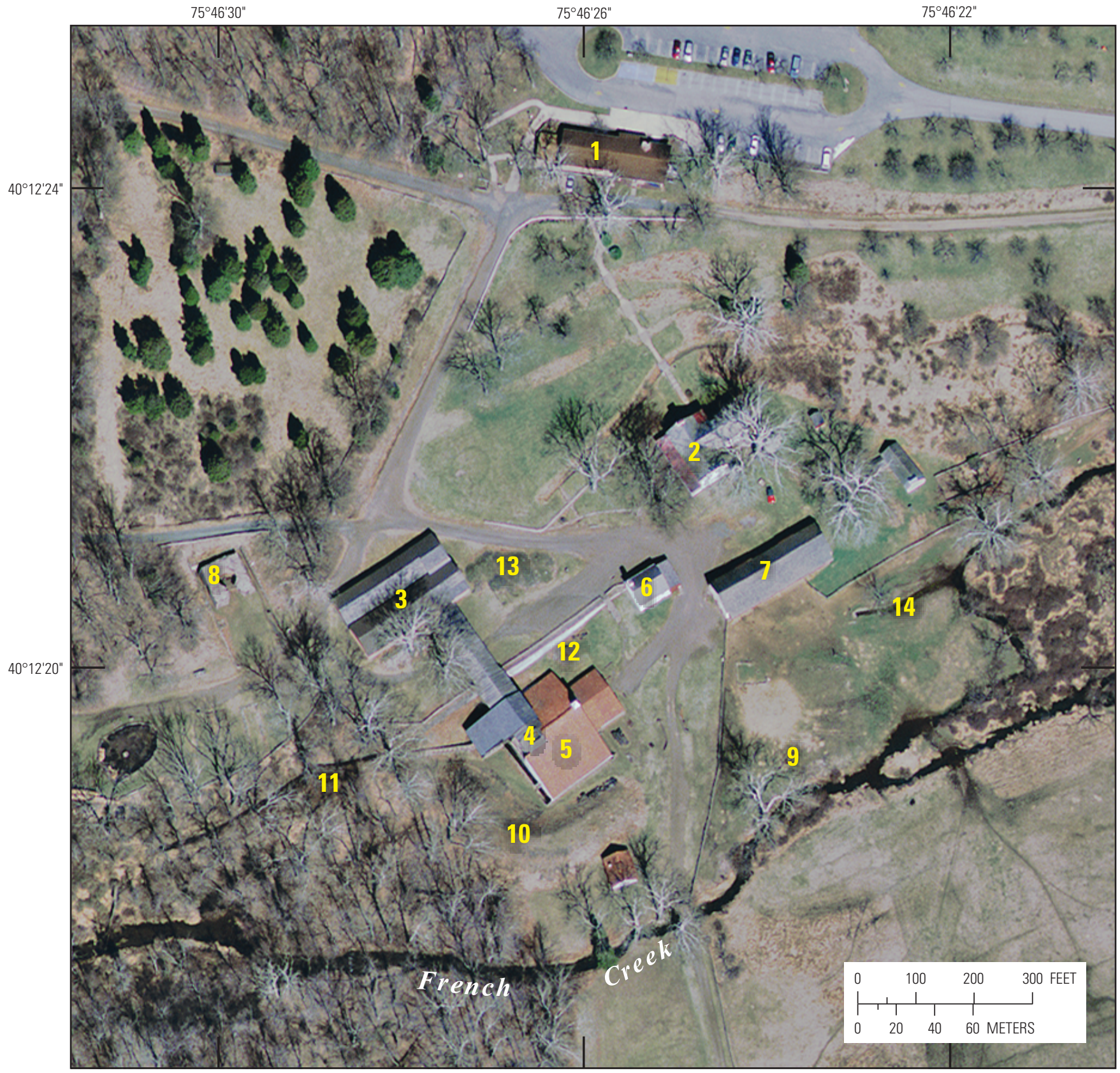

Aerial photograph courtesy of the Delaware Valley

Regional Planning Commission (DVRPC)
1. Visitor's center
2. Ironmaster's mansion
3. Charcoal house
4. Furnace
5. Cast house
6. Office and store
7. Barn
8. Anthracite furnace
9. Stockyard slag pile 1
10. Slag pile 2 (south and west of cast house)
11. Slag pile 3 (south of anthracite furnace)
12. Location of ore roaster
13. Ore pile
14. Tailrace

Figure 2. Locations of sampled slag piles at Hopewell Furnace National Historic Site, Pennsylvania. 
Local mines, mainly the Jones, Warwick, and Hopewell mines, supplied the iron ore used at Hopewell Furnace (fig. 3). The Hopewell mine, $2.8 \mathrm{mi}$ southwest of the furnace, and the Jones mine, $4.5 \mathrm{mi}$ southwest of the furnace, were owned by Hopewell Furnace and supplied most of the ore for the furnace. In later years, some ore came from the Warwick mine in Chester County. Iron ore used at Hopewell Furnace was mined from deposits of magnetite skarn and skarn replacements referred to as Cornwall-type ore bodies (Spencer, 1908) after the large iron ore body mined at Cornwall, Pa. The deposits were formed by replacement of carbonate-bearing rocks during contact metamorphism and metasomatism as a result of diabase intrusions during the early Jurassic. These deposits are mineralogically similar and contain abundant magnetite and accessory sulfide minerals enriched in arsenic, cobalt, copper, and other metals. Arsenic is a carcinogen (Agency for Toxic Substances and Disease Registry, 2007), and cobalt is a possible carcinogen (Agency for Toxic Substances and Disease Registry, 2004). Iron ore containing these trace metals was smelted at Hopewell Furnace during its 113 years of operation. The purpose of this study by the U.S. Geological Survey (USGS), in cooperation with the NPS, was to determine the distribution of trace metals in ore, slag, soil, streambed sediment, and water in Hopewell Furnace NHS related to the iron-smelting process.

\section{Purpose and Scope}

This report describes the distribution of trace metals in iron ore, slag, soil, cast iron furnace products, groundwater, stream base flow, and streambed sediment related to iron smelting in and around Hopewell Furnace NHS. In addition, the report presents results of benthic-macroinvertebrate and habitat surveys completed at five sites.

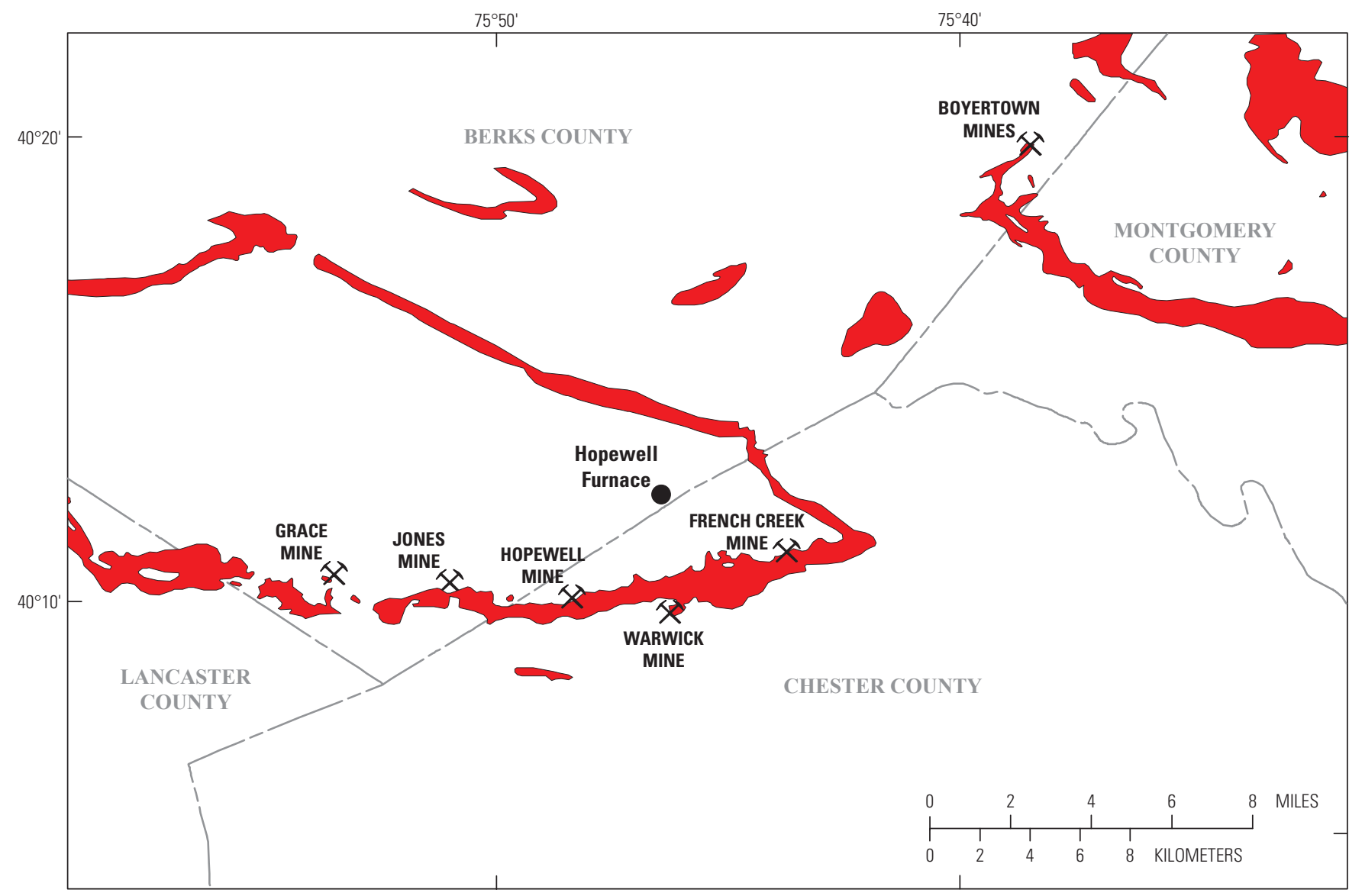

Base from U.S. Geological Survey digital data,1972,

1:2,000,000 Albers Equal-Area Conic Projection.

Standard parallels $29^{\circ} 30^{\prime} \mathrm{N}$, cental meridian $75^{\circ} 00^{\prime} \mathrm{W}$.

\section{EXPLANATION}

DIABASE

Figure 3. Locations of selected iron mines near Hopewell Furnace National Historic Site, Pennsylvania. 


\section{Historical Background}

William Bird was born in 1703. Bird initially worked for Thomas Rutter, a pioneer ironmaster, at nearby Pine Forge. When Bird later went into business for himself, he acquired extensive lands near Hay Creek where he built the New Pine Forges in 1744. At that time, he also began construction of Hopewell Forge, believed to have been located at, or near, the present Hopewell Furnace site. By 1756, he had acquired 12 tracts of land totaling about 3,000 acres.

Mark Bird, the son of William Bird, took charge of the family business upon his father's death in 1761 and expanded it. In 1770-71, Bird constructed Hopewell Furnace on French Creek. The location provided ready access to the raw materials necessary for maintaining an iron furnace-iron ore, limestone, and hardwood forests for making charcoal.

The opening of Hopewell Furnace coincided with the beginning of the Revolutionary War. Bird produced cannon shells and other supplies for the war, including the casting of 115 cannons for the Colonial Navy. In 1775, Bird served as lieutenant colonel of the Second Battalion, Berks County Militia. In August 1776, Colonel Bird outfitted 300 men of the battalion with uniforms, tents, and provisions at his own expense. This force marched under his command to Washington's relief after the Battle of Brandywine in late 1777. Bird was a member of the Provincial Conference of 1776 and was elected to the Provincial Assembly. Many of Bird's ironworks, gristmills, and sawmills supplied the Continental Congress with the materials for the Revolutionary War. Bird's patriotic endeavor nearly ruined him when the new government was unable to repay its debts following the Treaty of Paris. Compounding this, a flood on Hay Creek destroyed most of Bird's property there (Kurjack, 1954).

In 1783, Hopewell furnace produced 749.5 tons of pig iron and finished castings. Pig iron was its principal product. Finished castings included pots, kettles, stoves, hammers, anvils, and forge castings. While 1783 was a good year for iron production, the following years were not. In April 1786, Bird unsuccessfully tried to sell Hopewell Furnace along with his Birdsboro and Spring forges. In April 1788, Bird assigned Hopewell Furnace and his 5,000 acres of property to a creditor and moved to North Carolina where he died in poverty (Walker, 1966).

The furnace property changed ownership at least five times before 1800. At that time, Daniel Buckley and his brothers-in-law Thomas and Matthew Brooke purchased the property at auction. It was under the Brooke family that Hopewell reached its greatest prosperity. They updated the furnace technology, improved and extended the boundaries of the property, and rebuilt the waterwheel. A stamping mill was constructed in 1805 to salvage iron from the slag. From 1816 to 1848 , Clement Brooke, the son of Thomas Brooke, operated the furnace, first as resident manager and later as ironmaster. Clement Brooke was able to turn Hopewell into a major supplier of iron products. By the 1820 s, the furnace was operating at its peak, generally in excess of 300 days per year. Castings were the most profitable product, especially the popular Hopewell Stove. Hopewell produced as many as 23 types and sizes of cooking and heating stoves, which found a ready market in Philadelphia. Over 80,000 stoves were cast at Hopewell. In addition, Hopewell also cast pots, pans, kettles, bake plates, mortars, and waffle irons for the household; moldboards, corn-shelling machines, and windmill irons for the farmer; and machinery castings for industry.

The most productive years for Hopewell Furnace were from 1830 to 1837 . During 445 days of continuous production in 1836-37, 1,169 tons of castings were produced. Hopewell's products were so much in demand that the furnace was often forced to turn down orders from new customers. In 1837, an economic panic resulted in a large decline in demand for Hopewell stoves.

The depression of 1837, coupled with the successful introduction of the hot-blast method and the substitution of coke for charcoal in the smelting of iron, signaled the end of the charcoal-burning iron furnace era. Beginning in the 1840s, the iron industry shifted to large-scale, steam-driven coke and anthracite furnaces. By 1845, finished castings on a commercial scale were discontinued at Hopewell because of competition from the newer furnaces. Thereafter, the furnace concentrated on pig iron for which there was still a ready market.

Clement Brooke retired in 1848. His successors found, despite a short reprieve during the Civil War, they could not compete against the new iron and Bessemer steel industries. In 1849 , they erected an experimental anthracite furnace, which was to replace the old charcoal furnace. However, a poor design resulted in a catastrophic collapse of the furnace. In addition, the expense of hauling anthracite coal to Hopewell put an end to the experiment. The demand for iron during the Civil War and the simultaneous expansion of the railroad during the 1850 s and 1860 s temporarily brought the charcoal furnace back to life. When the iron and steel industries consolidated in urban manufacturing centers like Pittsburgh, Bethlehem, and Chicago, small independent rural enterprises like Hopewell could no longer compete, and the furnace ceased operating in 1883 (Kurjack, 1954).

In August 1935, the Federal government purchased over 4,000 acres of property that included the ruins of the iron furnace and community. The property was purchased for the French Creek Recreation Demonstration Area, one of five areas in Pennsylvania in the Recreation Demonstration Area Program, which was one of the many New Deal initiatives to help the nation recover from the Great Depression.

The Civilian Conservation Corps began to convert the land into a public recreation area and engaged the NPS to evaluate the furnace ruins found on the property. NPS historians recognized the value of the buildings in preserving the story of iron making in America and convinced the Department of the Interior that the furnace should be preserved and reconstructed. In 1938, the Acting Secretary of the Interior designated part of the land acquired for the French Creek Recreation Demonstration Area as Hopewell Village National Historic Site under the authority of the Historic Sites Act. The 
NPS set the current site boundaries in 1946 and changed the name to Hopewell Furnace National Historic Site in 1985. The land south of the furnace, which included the Hopewell mines, was given to the Commonwealth of Pennsylvania and became State Game Lands Number 43. Other land given to the Commonwealth of Pennsylvania became French Creek State Park (Glaser, 2005).

\section{The Iron-Making Process}

Hopewell Furnace, built in 1770-71, was one of the last of the charcoal-burning iron furnaces operated in Pennsylvania. It continued in operation long after most charcoal furnaces were replaced by furnaces that were more modern. It was one of the largest furnaces of its time with an annual capacity of 700 to 1,000 tons. Blast for the furnace was supplied by a bellows powered by a $22-\mathrm{ft}$ diameter water wheel.

The furnace was a truncated pyramid of thick stone $32 \mathrm{ft}$ high and $22 \mathrm{ft}$ square at the base built near the side of a small hill. Iron ore, charcoal, and limestone were carried across a wooden bridge that led from the hill to the opening of the furnace stack, into which they were dumped in alternating layers (fig. 4). Charcoal was the fuel used to smelt the iron ore. The blast was turned in, burning the charcoal at white heat $\left(2,600\right.$ to $\left.3,000^{\circ} \mathrm{F}\right)$ and melting the iron, which then dropped down to the hearth below. The slag, formed by the chemical fusion of the limestone with the impurities in the ore, floated on top and was drawn off from time to time and dumped outside the furnace. About twice a day, sometimes more often, the molten iron was run into a casting bed of sand. It required about 2 tons of ore, 1 to 2 tons of charcoal, and a few shovelfuls of limestone to make 1 ton of pig iron (Kurjack, 1954).

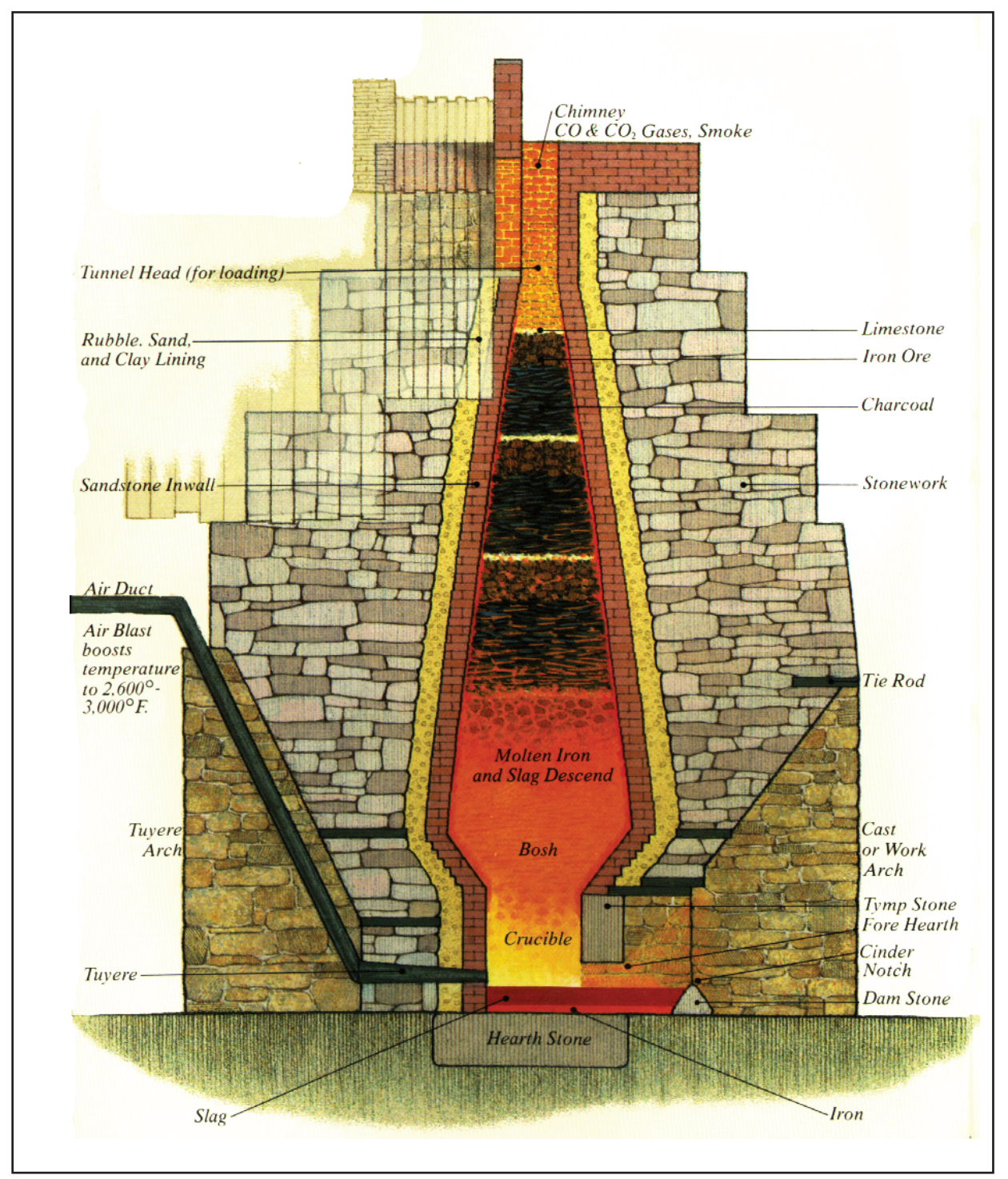

Figure 4. Cross-section diagram of a charcoal iron furnace. 


\section{Distribution of Trace Metals}

Trace metals from iron ore smelted at Hopewell Furnace could potentially follow several pathways (fig. 5). During the smelting process, trace metals could be (1) volatilized as air emissions by the high temperatures of the furnace, (2) combined with slag, or (3) combined with the iron and incorporated into the cast iron products of the furnace.

Volatilized metals likely were deposited on the land surface downwind from the furnace. Travel distance may have been short because of the low height $(32 \mathrm{ft}$ ) of the furnace stack. Metals deposited as aerosols may wash off into the surface-water system, be adsorbed onto soil, or be taken up by plants and animals. Erosion could move some of the soil and plant material into the stream system where it would become stream sediment.

Some of the trace metals were incorporated into the slag, which is a glass-like waste material discarded near the furnace. Trace metals present in slag may be immobile or, during physical and chemical weathering, could have leached into the soil or groundwater and surface-water system. Shallow, local groundwater discharges directly to French
Creek as base flow (low streamflow). Physical breakdown of the slag may provide metals as solids to the soil or stream sediment.

\section{Ore}

Iron ore is the primary source of trace metals present at Hopewell Furnace. Three local mines, the Jones, Hopewell, and Warwick mines (fig. 3), supplied the iron ore used by the furnace. These mines worked iron deposits of a similar origin with a similar mineralogy. The ore bodies contained abundant magnetite and accessory sulfide minerals enriched in arsenic, cobalt, copper, and other trace metals. The major sulfide minerals are chalcopyrite $\left(\mathrm{CuFeS}_{2}\right)$ and pyrite $\left(\mathrm{FeS}_{2}\right)$. Sloto and Dickinson (1994) listed the arsenic-bearing minerals cobaltite $[(\mathrm{Ni}, \mathrm{Co}, \mathrm{Fe}) \mathrm{AsS}]$ and erythrite $\left[\mathrm{Co}_{3}\left(\mathrm{AsO}_{4}\right) \mathrm{X} 8 \mathrm{H}_{2} \mathrm{O}\right]$ as accessory minerals associated with iron ore from the French Creek mine, which is 2.7 mi southeast of Hopewell Furnace (fig. 3). Smith and others (1988) presented analyses of ore samples from mines in Cornwall-type ore bodies in southeastern Pennsylvania that showed enrichment in arsenic, cobalt, copper, and nickel (table 1).

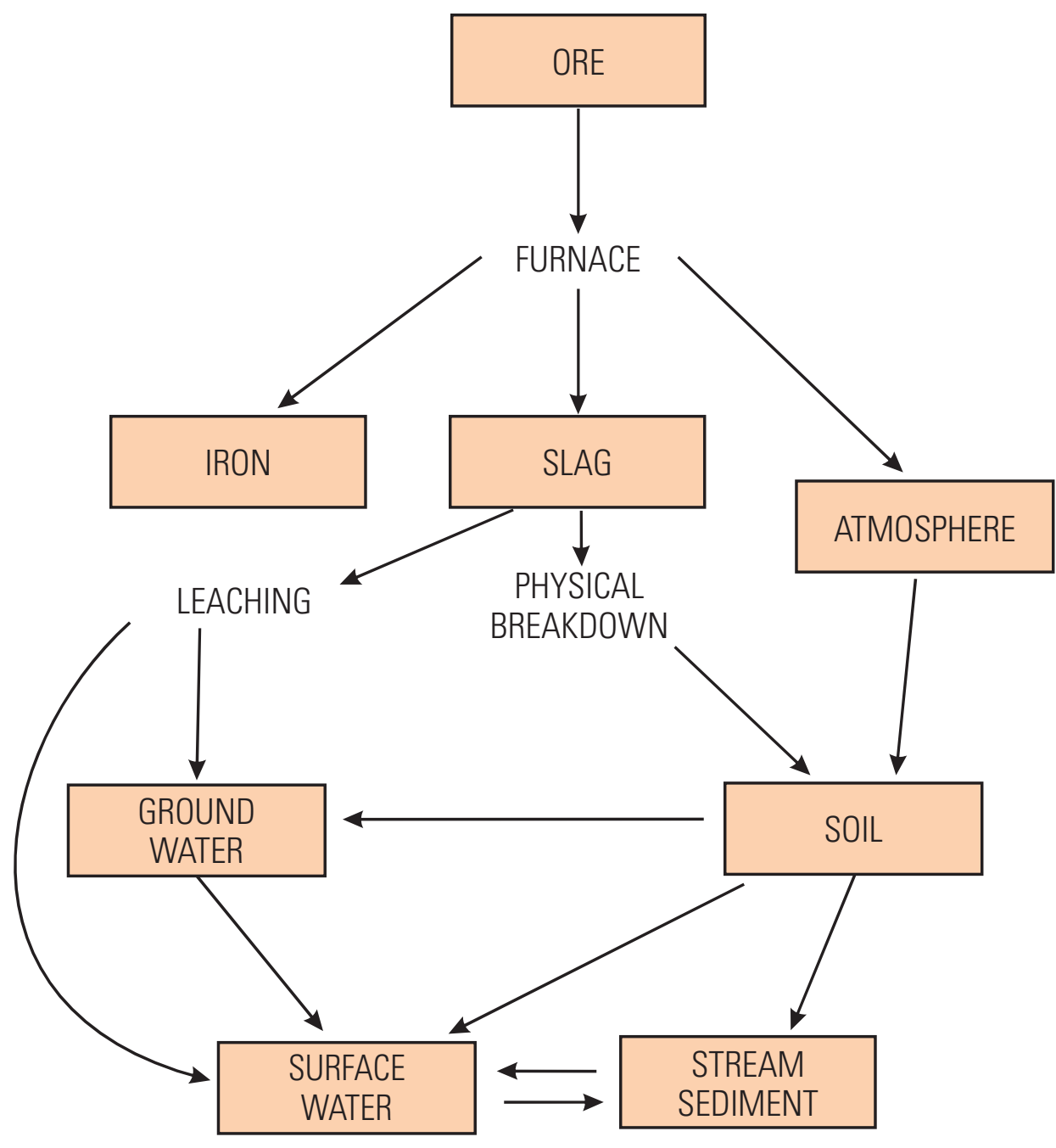

Figure 5. Potential pathways for migration of metals at Hopewell Furnace National Historic Site, Pennsylvania. 
Ore samples from the Hopewell and Jones mines were analyzed for this study. Samples from the Hopewell mine were collected from the mine dumps at the eastern, western, and northern open pits (Sloto, 2009, p. 242-249) and composited. The samples were divided into pure or nearly pure magnetite (Ore-1) and magnetite with some sulfide mineralization (Ore-2). Although permission to collect samples from the Jones mine dumps could not be obtained, ore samples from this source were provide by Gregory Kolous of Kutztown University. The samples were obtained from one location in the extensive mine dumps and are not representative of the ore materials. The Warwick mine dumps were not accessible. Complete analyses of ore samples from the Hopewell and Jones mines are given in tables A and B in the appendix. Selected trace metals are summarized in table 2 .

The bulk chemical composition of ore samples collected for this study was determined using inductively coupled plasma-atomic emission spectrometry (ICP-AES) and inductively coupled plasma-mass spectrometry (ICP-MS). The samples were decomposed using a mixture of hydrochloric, nitric, perchloric, and hydrofluoric acids at low temperature prior to analysis. Major oxide content was measured using wavelength dispersive X-ray fluorescence spectroscopy (WDXRF). The samples were fused with 50/50 lithium metaborate lithium tetraborate flux, and the resultant glass disk was irradiated in a wavelength dispersive X-ray spectrometer using a Rhodium

Table 1. Concentrations of selected trace metals in ore samples from iron mines in southeastern Pennsylvania.

[ From Smith and others (1988, p. 330); sample numbers are those of Smith and others (1988, p. 330); ppm, parts per million; <, less than]

\begin{tabular}{|c|c|c|c|c|c|c|c|}
\hline Mine & $\begin{array}{l}\text { Sample } \\
\text { number }\end{array}$ & Sample composition & $\begin{array}{c}\text { Arsenic } \\
\text { (ppm) }\end{array}$ & $\begin{array}{l}\text { Cobalt } \\
\text { (ppm) }\end{array}$ & $\begin{array}{c}\text { Copper } \\
\text { (ppm) }\end{array}$ & $\begin{array}{c}\text { Gold } \\
\text { (ppm) }\end{array}$ & $\begin{array}{c}\text { Nickel } \\
\text { (ppm) }\end{array}$ \\
\hline Jones mine & 16 & typical ore from dump & 5 & 200 & 17,900 & $<0.03$ & 335 \\
\hline Grace mine & 20 & chalcopyrite, magnetite, and hematite from dumps & 60 & 520 & 2,300 & 0.031 & 27 \\
\hline Cornwall mine & 6 & highgraded core & 75 & 790 & 6,900 & 0.188 & 185 \\
\hline Cornwall mine & 9 & pyrite mill concentrates & 220 & 11,000 & 900 & $<0.03$ & 1,110 \\
\hline Cornwall mine & 10 & magnetite mill concentrates & 5 & 50 & 300 & $<0.03$ & 10 \\
\hline Boyertown mine & 25 & magnetite, chalcopyrite, and malachite from dumps & 80 & 145 & 1,600 & 0.094 & 155 \\
\hline
\end{tabular}

${ }^{1}$ From Rudnick and Gao (2003, p. 5-6).

Table 2. Concentrations of selected trace metals in ore samples from the Hopewell and Jones mines, southeastern Pennsylvania. Location of mines shown on figure 3.

[Laboratory analyses by SGS Laboratories,Toronto, Ontario, Canada; ppm, parts per million; <, less than; >, greater than; --, unable to compute statistic]

\begin{tabular}{|c|c|c|c|c|c|c|c|c|c|c|}
\hline $\begin{array}{c}\text { Sample } \\
\text { identification } \\
\text { number }\end{array}$ & $\begin{array}{c}\text { Arsenic } \\
\text { (ppm) }\end{array}$ & $\begin{array}{l}\text { Chromium } \\
\text { (ppm) }\end{array}$ & $\begin{array}{l}\text { Cobalt } \\
\text { (ppm) }\end{array}$ & $\begin{array}{l}\text { Copper } \\
\text { (ppm) }\end{array}$ & $\begin{array}{c}\text { Iron } \\
\text { (percent) }\end{array}$ & $\begin{array}{l}\text { Lead } \\
\text { (ppm) }\end{array}$ & $\begin{array}{c}\text { Manganese } \\
\text { (ppm) }\end{array}$ & $\begin{array}{c}\text { Nickel } \\
\text { (ppm) }\end{array}$ & $\begin{array}{l}\text { Vanadium } \\
\text { (ppm) }\end{array}$ & $\begin{array}{c}\text { Zinc } \\
\text { (ppm) }\end{array}$ \\
\hline \multicolumn{11}{|c|}{ Hopewell mine } \\
\hline Ore-1 & 1 & 7 & 30.3 & 3.5 & $>15$ & 4 & 1,930 & 93.6 & 446 & 594 \\
\hline Ore-2 & 107 & 7 & 63 & 349 & $>15$ & 328 & 3,160 & 36.9 & 37 & 2,000 \\
\hline \multicolumn{11}{|c|}{ Jones mine } \\
\hline Ore-4 & 11 & $<1$ & 94.8 & $>10,000$ & $>15$ & 156 & 853 & 73.6 & 219 & 558 \\
\hline Ore-5 & 11 & 7 & 76.7 & 9,080 & $>15$ & 10.3 & 992 & 122 & 64 & 59 \\
\hline Mean & 28.4 & -- & 74.8 & -- & $>15$ & 184 & 1,550 & 76.5 & 205 & 726 \\
\hline Crustal abundance $^{1}$ & 4.8 & 92 & 17.3 & 28 & 3.9 & 17 & 77.5 & 47 & 97 & 67 \\
\hline
\end{tabular}

${ }^{1}$ From Rudnick and Gao (2003, p. 4-6). 
$\mathrm{X}$-ray tube. The mineralogy of the ore samples is described in a separate USGS report (N. M. Piatak and R. R. Seal II, U.S. Geological Survey, written commun., 2011).

Most ore samples contained elevated concentrations of arsenic, cobalt, copper, iron, lead, manganese, nickel, vanadium, and zinc (table 2) when compared to the crustal abundance of these metals reported by Rudnick and Gao (2003, p. 4-6).

\section{Slag}

Slag samples for laboratory analysis were collected from three slag piles: in the stockyard south and southeast of the barn (pile 1 on figure 6), south and west of the cast house (pile 2 on figure 6), and south of the anthracite furnace ruins (pile 3 on figure 6). Detailed results of the slag analyses are given in tables $\mathrm{C}$ and $\mathrm{D}$ in the appendix. Selected trace metals analyzed in the slag samples are summarized in table 3 . Concentrations of trace metals in the slag samples were compared to mean concentrations in soil in the eastern United States (east of the 96th meridian) published by Shacklette and Boerngen (1984, p. 6) (table 4). Their sample sites were about $50 \mathrm{mi}$ apart, and samples were collected from $20 \mathrm{~cm}$ below land surface.

The bulk chemical composition of slag samples collected for this study was determined using ICP-AES and ICP-MS. The samples were decomposed using a mixture of hydrochloric, nitric, perchloric, and hydrofluoric acids at low temperature prior to analysis. Major oxide content was measured using WDXRF. The samples were fused with 50/50 lithium metaborate lithium tetraborate flux, and the resultant glass disk was

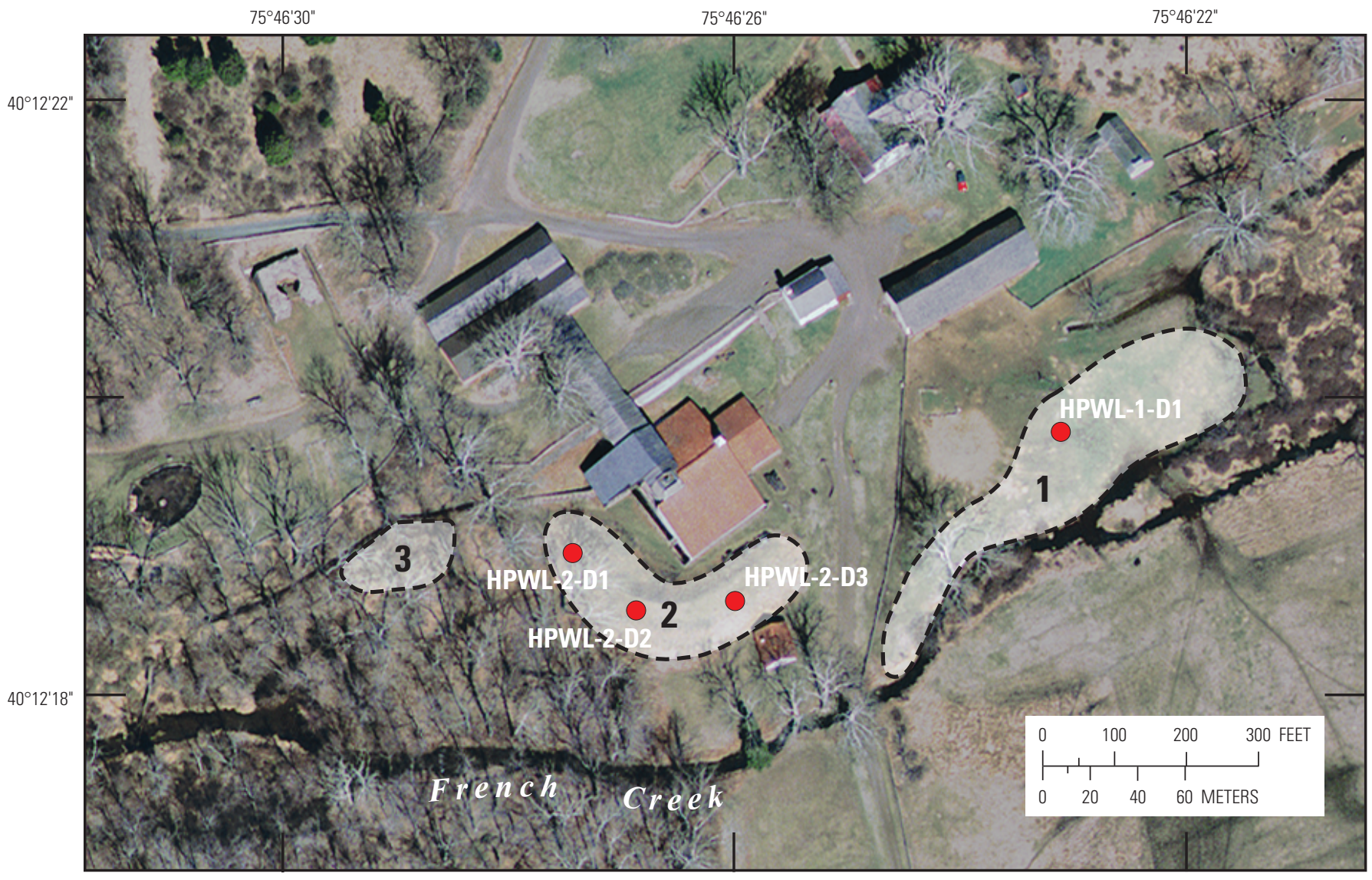

Aerial photograph courtesy of the Delaware Valley Regional Planning Commission (DVRPC)

\section{EXPLANATION}

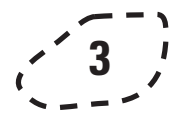

Approximate location of slag pile and number Location of auger hole and sample number

Figure 6. Locations of slag samples collected at Hopewell Furnace National Historic Site, Pennsylvania. 


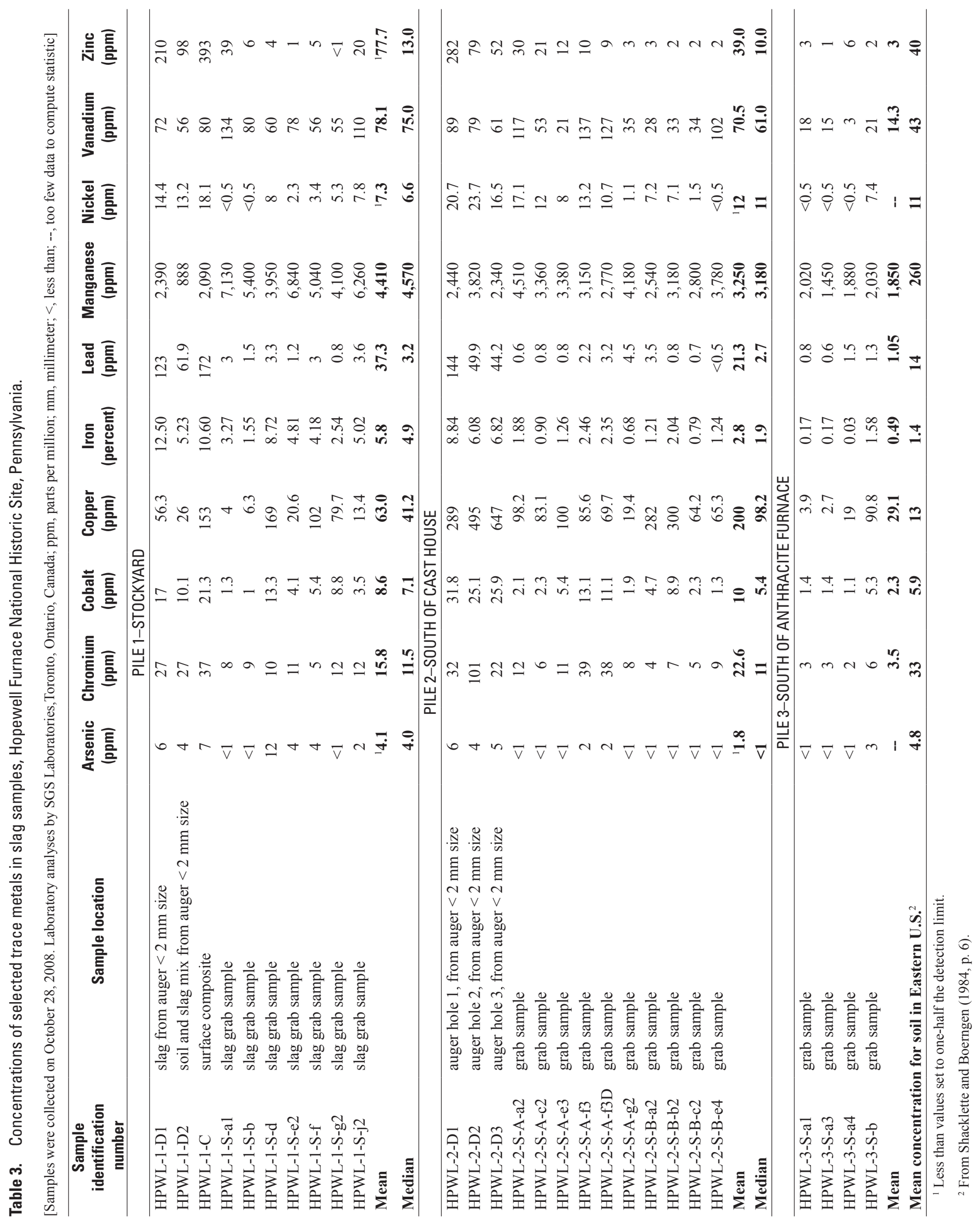


irradiated in a wavelength dispersive X-ray spectrometer using a Rhodium X-ray tube. The mineralogy and geochemistry of the slag samples are described in a separate USGS report (N.M. Piatak and R.R. Seal, II, U.S. Geological Survey, written commun., 2011).

The large slag pile in the stockyard south of the barn (pile 1 on figure 6) makes up the left bank of French Creek and has little soil cover. The slag is representative of slag produced by Hopewell Furnace; however, the age of the slag is unknown. Slag samples were collected from the surface and from an auger hole (HPWL-1-D1 on figure 6) used to install a well for groundwater sampling.

The mean concentrations of arsenic, chromium, cobalt, and nickel in the slag samples from the stockyard pile (pile 1 on figure 6) were less than or just slightly higher than the mean soil concentrations for the eastern United States (table 3). The arsenic concentrations ranged from less than 1 to $12 \mathrm{ppm}$, and the mean was $4.1 \mathrm{ppm}$. The chromium concentrations ranged from 5 to $37 \mathrm{ppm}$, and the mean was $15.8 \mathrm{ppm}$. The cobalt concentrations ranged from 1 to $21.3 \mathrm{ppm}$, and the mean was $8.6 \mathrm{ppm}$. The nickel concentrations ranged from less than 0.5 to $18.1 \mathrm{ppm}$, and the mean was $7.3 \mathrm{ppm}$.

The mean concentrations of copper, lead, vanadium, and zinc in the slag samples from the stockyard pile 1 were higher than the mean soil concentrations for the eastern United States (table 3 ). The copper concentrations ranged from 4 to $169 \mathrm{ppm}$, and the mean was $63 \mathrm{ppm}$. The lead concentrations ranged from 0.8 to $172 \mathrm{ppm}$, and the mean was $37 \mathrm{ppm}$. The vanadium concentrations ranged from 55 to $134 \mathrm{ppm}$, and the mean was $78 \mathrm{ppm}$. The zinc concentrations ranged from less than 1 to $393 \mathrm{ppm}$, and the mean was $78 \mathrm{ppm}$.

The manganese and iron concentrations in the slag samples from the stockyard pile 1 were substantially higher than the mean soil concentration for the eastern United States (table 3). The iron concentrations ranged from 15,500 to $125,000 \mathrm{ppm}$ ( 1.55 to 12.5 percent), and the mean was $58,000 \mathrm{ppm}$ (5.8 percent). The manganese concentrations ranged from 888 to $7,130 \mathrm{ppm}$, and the mean was $4,410 \mathrm{ppm}$.

The slag in the pile south and west of the cast house (pile 2 on figure 6) was not produced at Hopewell Furnace but was brought in from another site for display to park visitors (Rebecca Ross, National Park Service, oral commun., 2008). A path used by park visitors runs along the top of the pile. Samples were collected from three auger holes drilled into the pile (sites HPWL-2-D1, HPWL-2-D2, and HPWL-2-D3 on figure 6) and from the surface of the pile. The mean concentrations of arsenic, chromium, cobalt, iron, lead, nickel, and zinc (table 3) were less than or just slightly higher than the mean soil concentrations for the eastern United States (table 4). Concentrations of vanadium were higher, and concentrations of copper and manganese were substantially higher than the mean soil concentrations for the eastern United States. The cast-house slag pile contained substantially more copper and less arsenic, iron, manganese, and zinc than the stockyard slag pile produced at Hopewell Furnace.
Table 4. Mean concentration and range for selected trace metals in soil in the eastern United States.

[From Shacklette and Boerngen (1984, p. 6); concentrations given in parts per million; <, less than; >, greater than]

\begin{tabular}{|c|c|c|}
\hline Element & Mean concentration & Observed range \\
\hline Aluminum & 33,000 & $7,000->100,000$ \\
\hline Antimony & 0.52 & $<1-8.8$ \\
\hline Arsenic & 4.8 & $<0.1-73$ \\
\hline Barium & 290 & $10-1,500$ \\
\hline Beryllium & 0.55 & $<1-7$ \\
\hline Bromine & 0.62 & $<0.5-53$ \\
\hline Cerium & 63 & $<150-300$ \\
\hline Chromium & 33 & $1-1,000$ \\
\hline Cobalt & 5.9 & $<0.3-70$ \\
\hline Copper & 13 & $<1-700$ \\
\hline Gallium & 9.3 & $<5-70$ \\
\hline Iron & 14,000 & $100->100,000$ \\
\hline Lanthanum & 29 & $<30-200$ \\
\hline Lead & 14 & $<10-300$ \\
\hline Lithium & 17 & $<5-140$ \\
\hline Manganese & 260 & $<2-7,000$ \\
\hline Mercury & 0.081 & $0.01-3.4$ \\
\hline Molybdenum & 0.32 & $<3-15$ \\
\hline Niobium & 10 & $<10-50$ \\
\hline Nickel & 11 & $<5-700$ \\
\hline Rubidium & 43 & $<20-160$ \\
\hline Scandium & 6.5 & $<5-30$ \\
\hline Selenium & 0.3 & $<0.1-3.9$ \\
\hline Strontium & 53 & $<5-700$ \\
\hline Thorium & 7.7 & $2.2-23$ \\
\hline Tin & 0.86 & $<0.1-10$ \\
\hline Titanium & 2,800 & $70-15,000$ \\
\hline Uranium & 2.1 & $0.29-11$ \\
\hline Vanadium & 43 & $<7-300$ \\
\hline Yttrium & 20 & $<10-200$ \\
\hline Zinc & 40 & $<5-2,900$ \\
\hline Zirconium & 220 & $<20-2,000$ \\
\hline
\end{tabular}

The slag pile south of the anthracite furnace ruins (pile 3 on figure 6) may have been produced by the anthracite furnace experiment in 1849. Mean concentrations of all metals listed in table 3 were less than those of the stockyard slag pile. However, slag pile 3 had the greatest mean concentrations of beryllium, lithium, scandium, strontium, thorium, uranium, and yttrium of the three piles (appendix table $\mathrm{C}$ ). 


\section{Soil}

Three sets of soil samples were collected. (1) An initial set of soil samples was collected for laboratory analysis. (2) A second set of samples was collected and analyzed onsite with a portable XRF spectrometer at approximately 3 -cm depth intervals. (3) On the basis of the results of the XRF analysis, a set of follow-up samples were collected for laboratory analysis.

Initial soil samples were collected from two sites downwind of the furnace (SOIL-1 and SOIL-2) and from a background site $3,400 \mathrm{ft}$ northeast of the furnace (SOIL-3) (fig. 7). Downwind direction was determined from the wind rose for the Reading Regional Airport (Pennsylvania State University, 2009), which is approximately $16 \mathrm{mi}$ northwest of Hopewell Furnace. The most frequent wind direction (resultant vector) is from 289 degrees resulting in a downwind direction of 109 degrees. One soil core to about $3 \mathrm{ft}$ below land surface was collected at each site using a stainless steel core-sampling tube with a 1-in. diameter plastic sleeve. Bulk chemical composition of soil samples collected for this study analyzed in the laboratory (table 5 at end of report and appendix tables E and F) was determined using ICP-AES and ICP-MS. The samples were decomposed using a mixture of hydrochloric, nitric, perchloric, and hydrofluoric acids at low temperature prior to analysis. Major oxide content was measured using WDXRF. The samples were fused with 50/50 lithium metaborate lithium tetraborate flux, and the resultant glass disk was irradiated in a wavelength dispersive X-ray spectrometer using a Rhodium $\mathrm{X}$-ray tube. Selected trace metals in soil samples analyzed in the laboratory are summarized in table 5. Complete laboratory analyses are given in tables $\mathrm{E}$ and $\mathrm{F}$ in the appendix. Concentrations of metals regulated by the Pennsylvania Department of Environmental Protection (PaDEP) (table 6) were below standards for non-residential soil.

Additional soil samples were collected near the ore roaster, the ore pile, and on the south side of French Creek (SOIL-5, SOIL-6, SOIL-7, and SOIL-8 on figure 7). At each sample site, one soil core approximately 1 to $3 \mathrm{ft}$ deep was collected using a stainless steel core-sampling tube with a 1 -in. diameter plastic sleeve. Samples were analyzed onsite by Cynthia Hall and Martin Helmke of West Chester University and Michael Degnan of the USGS using a portable XRF spectrometer. The portable XRF spectrometer is accepted by the U.S. Environmental Protection Agency (USEPA) for screening purposes (U.S. Environmental Protection Agency, 2010a); it's use is described under USEPA method 6200 (U.S. Environmental Protection Agency, 2007). Complete analyses for samples analyzed by XRF are given in table $G$ in the appendix, and selected constituents are summarized in table 7 (at end of report); these results should be considered screening-level results.

The field XRF analyses (table 7) indicated that the highest metal concentrations were in about the first foot $(35 \mathrm{~cm})$ of soil below the land surface. The concentrations of arsenic, chromium, copper, and lead with depth at soil sampling location SOIL-5 are shown on figure 8.
Table 6. Pennsylvania Department of Environmental Protection statewide health standards for soil.

[Standards from Pennsylvania Department of Environmental Protection (2011); concentrations given in parts per million; Concentrations represent direct contact values.]

\begin{tabular}{lrr}
\hline Regulated constituent & $\begin{array}{r}\text { Residential soil } \\
\text { (0-15 feet) }\end{array}$ & $\begin{array}{r}\text { Non-residential soil } \\
\text { (0-2 feet) }\end{array}$ \\
\hline Aluminum & 190,000 & 190,000 \\
Antimony & 88 & 1,100 \\
Arsenic & 12 & 53 \\
Barium and compounds & 44,000 & 190,000 \\
Beryllium & 440 & 5,600 \\
Boron and compounds & 44,000 & 190,000 \\
Cadmium & 110 & 1,400 \\
Chromium III & 190,000 & 190,000 \\
Chromium VI & 660 & 8,400 \\
Cobalt & 66 & 840 \\
Copper & 8,100 & 100,000 \\
Iron & 150,000 & 190,000 \\
Lead & 500 & 1,000 \\
Manganese & 10,000 & 130,000 \\
Mercury & 35 & 450 \\
Nickel & 4,400 & 56,000 \\
Selenium & 1,100 & 14,000 \\
Silver & 1,100 & 14,000 \\
Thallium & 15 & 200 \\
Tin & 130,000 & 190,000 \\
Vanadium & 1,500 & \\
Zinc & 66,000 & \\
\hline & & 000 \\
\hline
\end{tabular}

Concentrations of metals regulated by the PaDEP (table 6) were below standards for non-residential soil except for three samples with elevated arsenic and seven samples with elevated iron concentrations from soil sampling location SOIL-5, which was near the ore roaster. Concentrations of arsenic in samples from 22.9 to $33 \mathrm{~cm}$ below land surface and concentrations of iron in samples from 15.2 to $35.6 \mathrm{~cm}$ below land surface exceeded the PaDEP standard (table 6). Ninetyfive percent of arsenic concentrations were below the minimum detection limit. All concentrations of barium, chromium, cobalt, copper, iron, lead, manganese, mercury, and zinc (table G) were below the PaDEP standards for non-residential soil. Antimony, bromine, cadmium, gold, mercury, molybdenum, nickel, rubidium, selenium, silver, strontium, and tin were not detected or, if present, the concentrations were below the minimum reporting level.

Concentrations of cobalt ranged from not detected to $3,710 \mathrm{ppm}$ with a median concentration of $345 \mathrm{ppm}$. Soil samples with the highest cobalt concentrations also had the highest iron concentrations. These elevated concentrations are likely the result of interference with high concentrations of iron, which were present in the samples. Three soil samples 

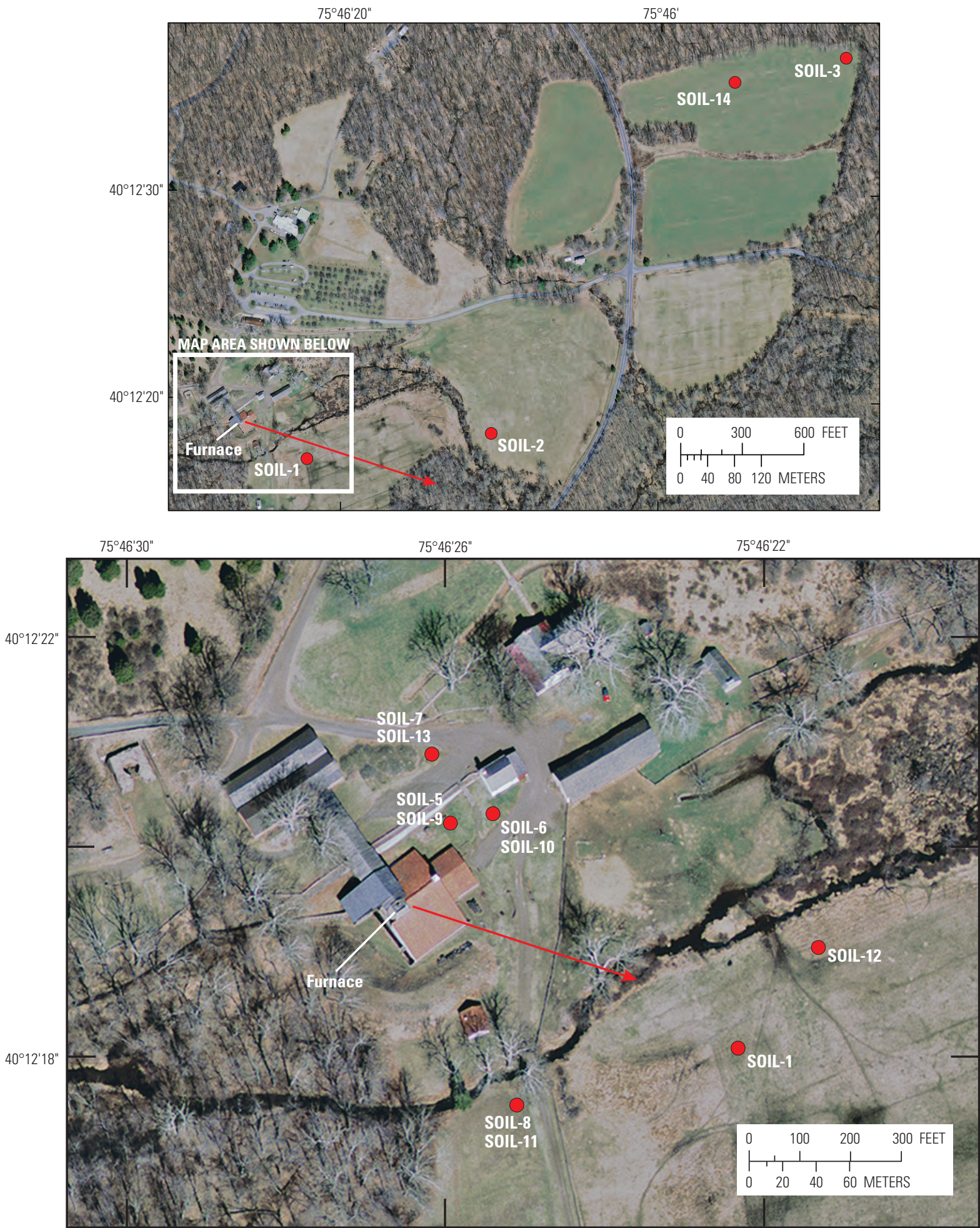

Aerial photograph courtesy of the Delaware Valley Regional Planning Commission (DVRPC)

\section{EXPLANATION}

$\longrightarrow \quad$ Most frequent wind direction—arrow shows resultant vector

SolL-1 Location of soil sample and sample number

Figure 7. Locations of soil samples collected at Hopewell Furnace National Historic Site, Pennsylvania. 
were split, with about two-thirds of the sample analyzed in the laboratory and one-third of the sample analyzed with the portable X-ray spectrometer. A comparison of sample results (table 8) shows that reported concentrations for cobalt were substantially higher and titanium concentrations were somewhat higher for the samples analyzed by XRF. Some differences in concentration may result from the different analytical techniques. For the laboratory analysis, the bulk of the sample was dissolved in acid and then analyzed. In contrast, concentrations measured by XRF may be strongly influenced by metals adsorbed onto the surface of soil particles. For the XRF analysis, the depth of penetration of X-rays depends on sample density and the source energy level. For example, the depth of penetration for cobalt is $0.07 \mathrm{~mm}$ at an energy level of $10 \mathrm{Kev}$ and $2.9 \mathrm{~mm}$ at an energy level of $40 \mathrm{Kev}$.

On the basis of the results from the portable XRF spectrometer, follow-up soil samples for laboratory analysis for bulk chemical composition were collected from the same areas (SOIL-9, SOIL-10, SOIL-11, and SOIL-13 on figure 7) and two additional areas (SOIL-12 and SOIL-14 on figure 7). At each sample site, three to four cores approximately $1 \mathrm{ft}$ deep were collected from an area about 6 in. in diameter using a stainless steel core-sampling tube with a 1-in. diameter plastic sleeve. The cores for each area were subdivided by depth and then composited for laboratory analysis. Complete analyses are given in tables $\mathrm{E}$ and $\mathrm{F}$ in the appendix. Selected trace metals in soil samples analyzed in the laboratory are summarized in table 5. Concentrations of all metals in soil samples analyzed in the laboratory were below PaDEP standards for non-residential soils (table 6).

Mean concentrations of arsenic, cobalt, manganese, nickel, and vanadium were similar in soil samples from the furnace area and samples from the background area. Concentrations of arsenic in soil near the furnace ranged from 3 to $9.2 \mathrm{ppm}$. The mean arsenic concentration was $5.4 \mathrm{ppm}$, which

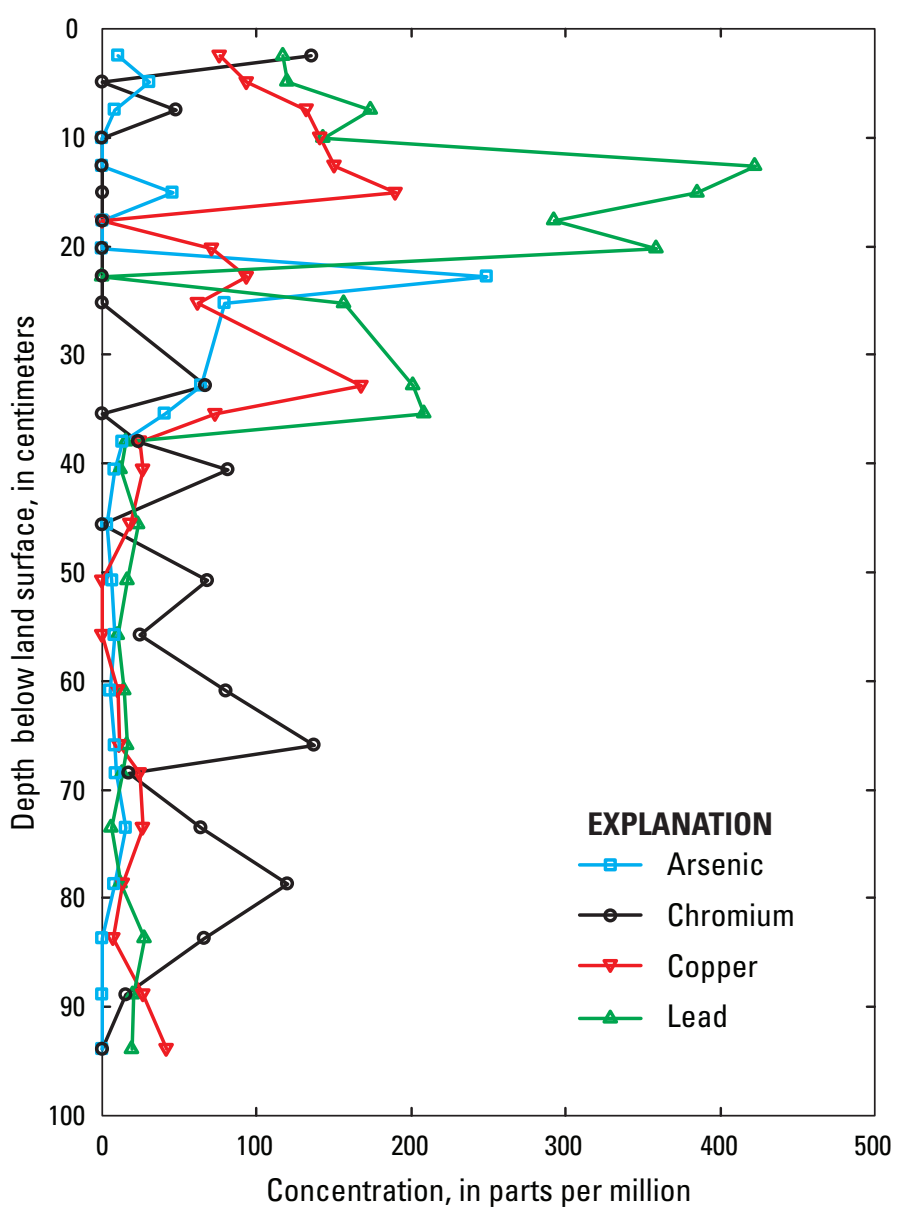

Figure 8. Vertical profile of arsenic, chromium, copper, and lead concentrations in soil at soil sampling site SOIL-5, Hopewell Furnace National Historic Site, Pennsylvania.

Table 8. Comparison of concentrations of selected trace metals in soils analyzed by inductively coupled plasma-atomic emission spectrometry and X-ray fluorescence spectroscopy, Hopewell Furnace National Historic Site, Pennsylvania.

[Laboratory analyses by SGS Laboratories, Toronto, Ontario, Canada; XRF analyses by Michael Degnan of the U.S. Geological Survey; XRF, X-ray fluorescence spectrometer; ppm, parts per million; ND, below detection limit of instrument; >, greater than]

\begin{tabular}{|c|c|c|c|c|c|c|c|c|c|c|c|}
\hline $\begin{array}{c}\text { Sample- } \\
\text { identification } \\
\text { number }\end{array}$ & $\begin{array}{l}\text { Number of XRF } \\
\text { measurements }\end{array}$ & $\begin{array}{c}\text { Arsenic } \\
\text { (ppm) }\end{array}$ & $\begin{array}{l}\text { Chromium } \\
\text { (ppm) }\end{array}$ & $\begin{array}{l}\text { Cobalt } \\
\text { (ppm) }\end{array}$ & $\begin{array}{c}\text { Copper } \\
\text { (ppm) }\end{array}$ & $\begin{array}{l}\text { Iron } \\
\text { (ppm) }\end{array}$ & $\begin{array}{l}\text { Lead } \\
\text { (ppm) }\end{array}$ & $\begin{array}{c}\text { Manganese } \\
\text { (ppm) }\end{array}$ & $\begin{array}{l}\text { Nickel } \\
\text { (ppm) }\end{array}$ & $\begin{array}{c}\text { Titanium } \\
\text { (ppm) }\end{array}$ & $\begin{array}{c}\text { Zinc } \\
\text { (ppm) }\end{array}$ \\
\hline \multicolumn{12}{|c|}{ SOIL-9_17-22 } \\
\hline XRF median & 18 & ND & ND & 2,990 & ND & 549,000 & 430 & 4,790 & ND & 6,300 & 860 \\
\hline Laboratory & & 10 & 11 & 45.6 & 115 & $>150,000$ & 558 & 2,560 & 53.4 & 1,800 & 562 \\
\hline \multicolumn{12}{|c|}{ SOIL-9_22-28 } \\
\hline Laboratory & & 10 & 15 & 38 & 139 & $>150,000$ & 310 & 1,990 & 47 & 1,700 & 415 \\
\hline \multicolumn{12}{|c|}{ SOIL-10_0-7 } \\
\hline XRF median & 13 & ND & ND & 1,020 & 68 & 113,000 & 154 & 2,420 & ND & 5,300 & 338 \\
\hline Laboratory & & 6 & 203 & 17 & 55 & 120,000 & 194 & 2,270 & 45 & 2,200 & 316 \\
\hline
\end{tabular}


was similar to the mean concentration of soil (5.4 ppm) in the background area and the mean eastern United States soil concentration (4.8 ppm). Concentrations of cobalt in soil near the furnace ranged from 3.7 to $45.6 \mathrm{ppm}$. The mean cobalt concentration was $16.3 \mathrm{ppm}$, which was similar to the mean concentration of soil $(13.9 \mathrm{ppm})$ in the background area and slightly higher than the mean eastern United States soil concentration $(5.9 \mathrm{ppm})$. Concentrations of manganese in soil near the furnace ranged from 109 to $2,700 \mathrm{ppm}$. The mean manganese concentration was $1,170 \mathrm{ppm}$, which was similar to the mean concentration of soil $(1,533 \mathrm{ppm})$ in the background area and substantially higher than the mean eastern United States soil concentration (260 ppm). Concentrations of nickel in soil near the furnace ranged from 10.5 to $53.8 \mathrm{ppm}$. The mean concentration was $28 \mathrm{ppm}$, which was similar to the mean concentration of soil (23 ppm) in the background area and slightly higher than the mean eastern United States soil concentration (11 ppm). Concentrations of vanadium in soil near the furnace ranged from 43 to $182 \mathrm{ppm}$. The mean concentration was $80.3 \mathrm{ppm}$, which was similar to the mean concentration of soil $(75.4 \mathrm{ppm})$ in the background area and higher than the mean eastern United States soil concentration (43 ppm).

Mean concentrations of chromium, copper, and iron were higher in soil samples from the furnace area and samples from the background area. Concentrations of chromium in soil near the furnace ranged from 11 to $239 \mathrm{ppm}$. The mean concentration was $48.8 \mathrm{ppm}$, which was higher than the mean concentration of soil (13.9 ppm) in the background area and the mean eastern United States soil concentration (5.9 ppm). Concentrations of copper in soil near the furnace ranged from 13.1 to $139 \mathrm{ppm}$. The mean concentration was $55.1 \mathrm{ppm}$, which was higher than the mean concentration of soil (23.4 ppm) in the background area and the mean eastern United States soil concentration (13 ppm). Concentrations of iron near the furnace ranged from 1.52 to greater than 15 percent. The mean concentration was 5.8 percent, which was higher than the mean concentration of soil (2.9 percent) in the background area and the mean eastern United States soil concentration (1 percent).

Mean concentrations of lead and zinc were substantially higher in soil samples from the furnace area. Concentrations of lead in soil near the furnace ranged from 8.8 to $646 \mathrm{ppm}$. The mean concentration was $125 \mathrm{ppm}$, which was substantially higher than the mean concentration of soil (22 ppm) in the background area and the mean eastern United States soil concentration (14 ppm). Concentrations of zinc in soil near the furnace ranged from 23 to $562 \mathrm{ppm}$. The mean concentration was $159 \mathrm{ppm}$, which was substantially higher than the mean concentration of soil $(55.8 \mathrm{ppm})$ in the background area and the mean eastern United States soil concentration (40 ppm).

\section{Cast Iron Furnace Products}

The trace-metal concentrations of cast iron furnace products produced at Hopewell Furnace were analyzed by Martin Helmke of West Chester University using a portable
XRF spectrometer. The XRF spectrometer was used because it could perform onsite, non-destructive, real-time analysis. The artifacts analyzed, which are on display in the Hopewell NHS museum, included eight cast iron stoves, a footed pot, and a kettle (fig. 9). In addition, a stove cast at the Rock Furnace in Lancaster County was analyzed. Complete analyses are given in table $\mathrm{H}$ in the appendix. Concentrations of selected trace metals are summarized in table 9.

Each stove was sampled three times on the ash lip and three times on the top. Mean concentrations are presented in table 9. For the statistics in table 9, zero was used for nondetection. Nickel was not detected in any sample. The mean arsenic concentration for stoves cast at Hopewell Furnace was $499 \mathrm{ppm}$, the mean cobalt concentration was $11,500 \mathrm{ppm}$, the mean copper concentration was $2,000 \mathrm{ppm}$, the mean lead concentration was $588 \mathrm{ppm}$, and the mean zinc concentration was 1,280 ppm (table 9). Elevated concentrations of cobalt are likely caused by interference from iron. Most concentrations of manganese were non-detect or below the detection limit. All concentrations of antimony, barium, chromium, mercury, silver, tin, and titanium were non-detect or below the detection limit. The stoves contained a mean concentration of $270 \mathrm{ppm}$ gold. Gold was reported in ore samples from Cornwall-type iron deposits by Smith and others (1988, p. 330) (table 1). The stove cast at Rock Furnace had no detectable copper, less cobalt and zinc, about the same arsenic and lead concentration, and substantially more manganese than the stoves cast at Hopewell Furnace.

\section{Groundwater}

Hopewell Furnace NHS uses one well as the sole source of water supply for park visitors, employees, and residents. The well is $150 \mathrm{ft}$ deep and cased to $65 \mathrm{ft}$ below land surface. It is approximately $2,500 \mathrm{ft}$ topographically upgradient from the furnace and slag piles. An unfiltered water sample was collected from the well for field $(\mathrm{pH}$, acid neutralizing capacity, specific conductance, dissolved oxygen, and water temperature) and laboratory analysis. Field meters used for water-chemistry measurements were calibrated daily using certified standards and buffers. Field-meter log books were kept with the meters to record calibration and performance information. Thermistors in the field instruments were checked against a National Institute of Standards and Technology certified thermometer (U.S. Geological Survey, 1997 to present). Groundwater samples were analyzed for nutrients, major ions, and metals at the USGS laboratory in Denver, Colo. Complete field and laboratory analyses are given in table I in the appendix, and selected constituents are summarized in table 10. The water from the supply well had a near neutral $\mathrm{pH}$ (7.2) and was low in dissolved solids (specific conductance of $209 \mu \mathrm{S} / \mathrm{cm}$ ). The well-water sample met all applicable USEPA drinking-water standards (table 11).

A temporary well was installed in slag pile 1 south of the barn at location HPWL-1-D1 on figure 6 using a 

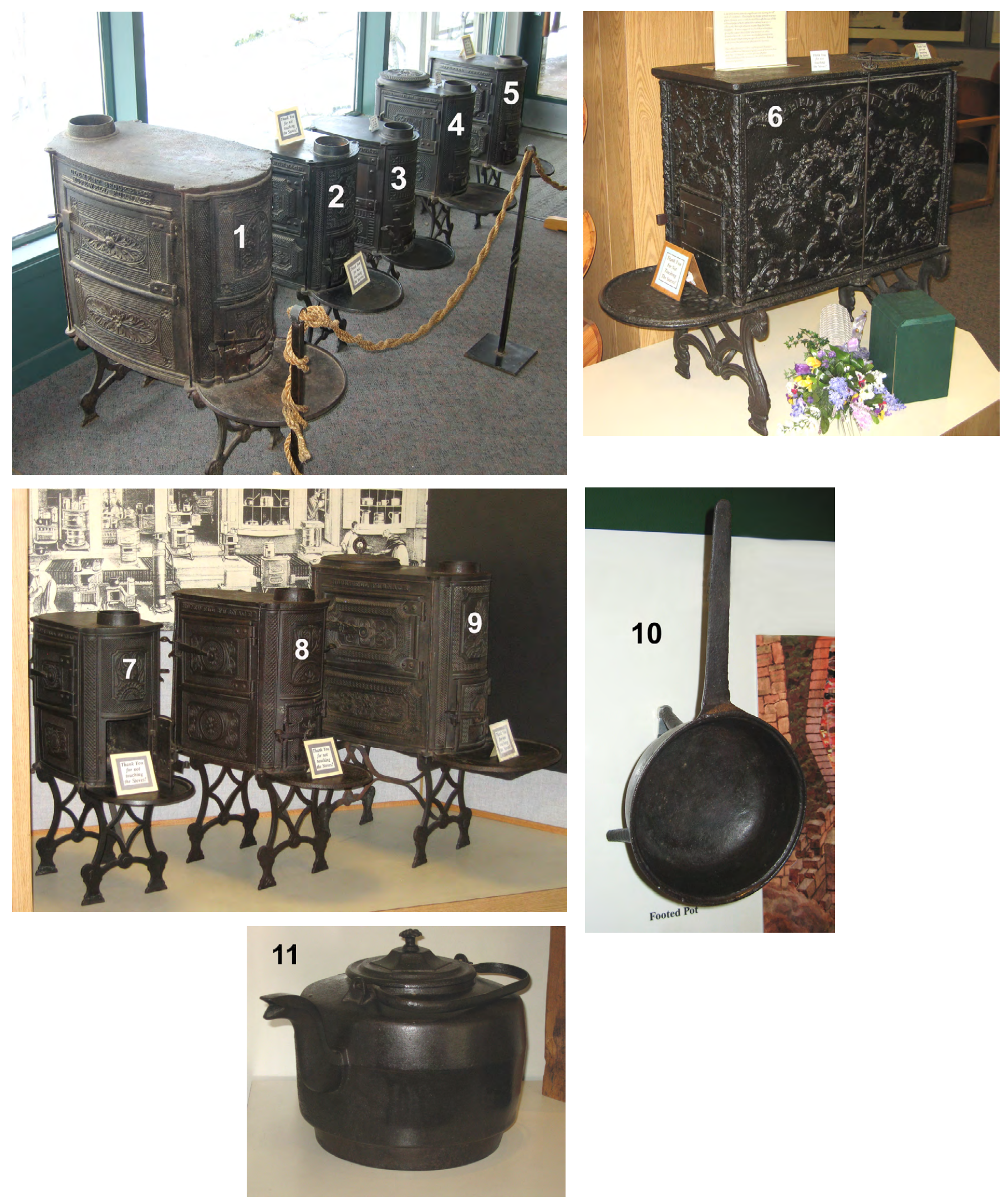

Figure 9. Cast iron artifacts in the Hopewell National Historic Site museum sampled for trace-metal concentrations using portable $X$-ray fluorescence spectroscopy. 


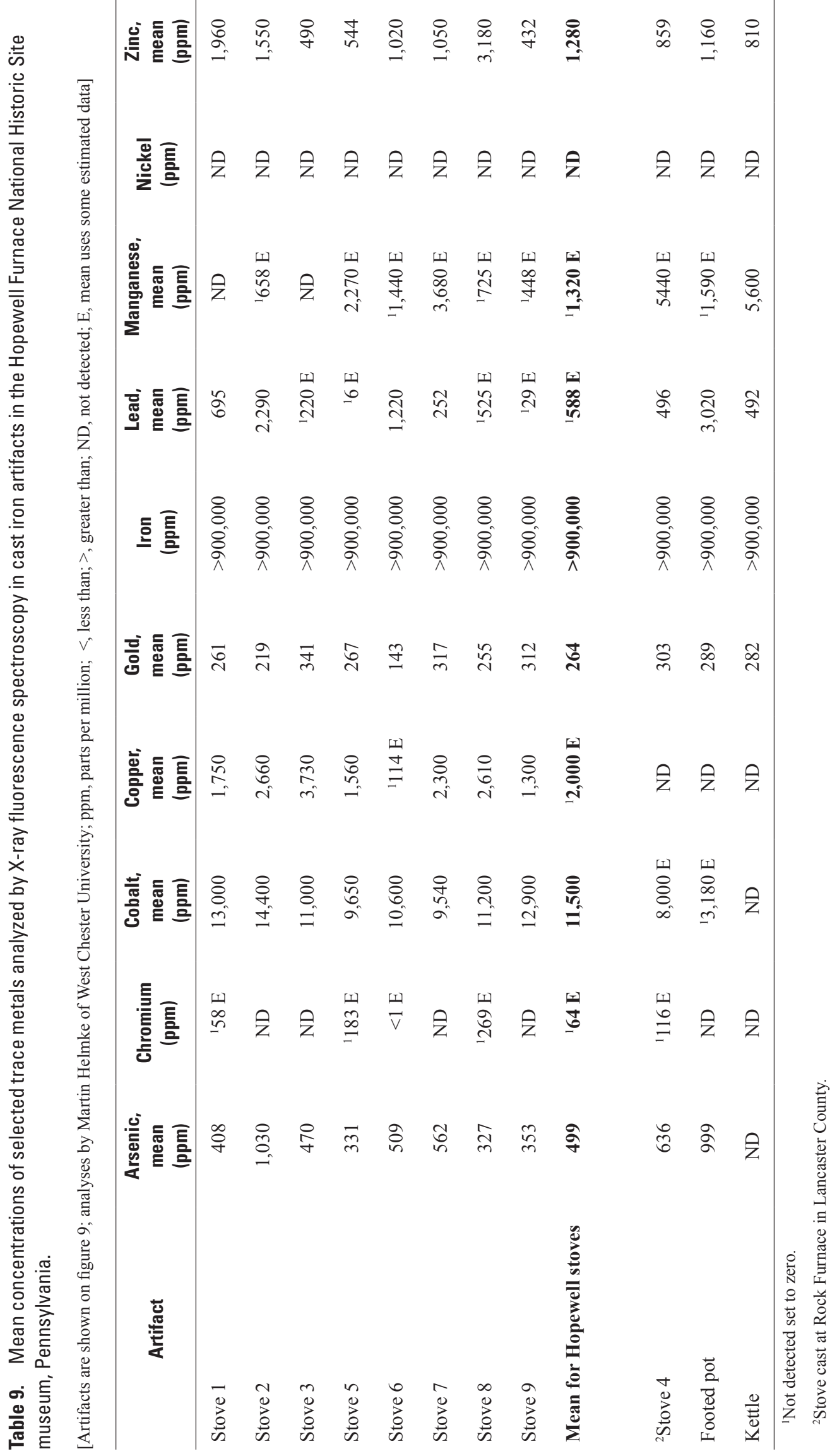


Table 10. Chemical analysis results for selected constituents in groundwater, Hopewell Furnace National Historic Site, Pennsylvania. [Laboratory analyses by USGS National Water Quality Laboratory, Denver, Colo.; USGS, U.S. Geological Survey; mg/L, milligrams per liter; $\mu \mathrm{g} / \mathrm{L}$, micrograms per liter; <, less than; E, estimated concentration; --, no drinking-water standard]

\begin{tabular}{|c|c|c|c|c|c|c|c|c|}
\hline Well and USGS identifier & $\begin{array}{c}\text { Depth of } \\
\text { well } \\
\text { (feet) }\end{array}$ & $\underset{\text { (units) }}{\mathrm{pH}}$ & $\begin{array}{l}\text { Specific con } \\
\text { (microsiemens p } \\
\text { at } 25 \text { degrees }\end{array}$ & $\begin{array}{l}\text { tance } \\
\text { entimeter } \\
\text { Isius) }\end{array}$ & $\begin{array}{c}\text { Dissolved } \\
\text { oxygen } \\
\text { (mg/L) }\end{array}$ & $\begin{array}{c}\text { Sulfate, } \\
\text { dissolved } \\
\text { (mg/L) }\end{array}$ & $\begin{array}{c}\text { Aluminum, } \\
\text { total } \\
(\mu \mathrm{g} / \mathrm{L})\end{array}$ & $\begin{array}{c}\text { Arsenic } \\
\text { total } \\
(\mu \mathrm{g} / \mathrm{L})\end{array}$ \\
\hline Supply well BE-523 & 150 & 7.2 & 209 & & 6.7 & 8.74 & 24 & 3.4 \\
\hline Slag pile well BE-1784 & 13 & 7.0 & 87 & & 9.6 & 3.19 & 570 & 0.8 \\
\hline Drinking-water standard ${ }^{1}$ & & $6.5-8.5$ & -- & & -- & 250 & $50-200$ & 10 \\
\hline Supply well BE-523 & 0.73 & $<0.1$ & $<4$ & 32 & 0.35 & 0.9 & 0.3 & 6.1 \\
\hline Slag pile well BE-1784 & 1.2 & 3.9 & $3.4 \mathrm{E}$ & 1,740 & 13.7 & 2,430 & 2.5 & 11.6 \\
\hline Drinking-water standard $^{1}$ & 100 & -- & 1,000 & 300 & 15 & 50 & -- & 5,000 \\
\hline
\end{tabular}

${ }^{1}$ From U.S. Environmental Protection Agency (2009).

Table 11. U.S. Environmental Protection Agency maximum contaminant, secondary contaminant, and action levels for constituents in drinking water.

[From U.S. Environmental Protection Agency (2009); --, no standard]

\begin{tabular}{|c|c|c|c|}
\hline Regulated constituent & $\begin{array}{c}\text { Maximum } \\
\text { contaminant level } \\
\text { (micrograms per liter) }\end{array}$ & $\begin{array}{c}\text { Action level }^{1} \\
\text { (micrograms per liter) }\end{array}$ & $\begin{array}{c}\text { Secondary maximum } \\
\text { contaminant level } \\
\text { (milligrams per liter) }\end{array}$ \\
\hline Aluminum & -- & -- & $0.050-0.2$ \\
\hline Antimony & 6 & -- & -- \\
\hline Arsenic & 10 & -- & -- \\
\hline Barium & 2,000 & -- & -- \\
\hline Beryllium & 4 & -- & -- \\
\hline Cadmium & 5 & -- & -- \\
\hline Chromium, total & 100 & -- & -- \\
\hline Chloride & -- & -- & 250 \\
\hline Copper & -- & 1,300 & 1 \\
\hline Iron & -- & -- & 0.3 \\
\hline Lead & -- & 15 & -- \\
\hline Manganese & -- & -- & 0.05 \\
\hline Mercury & 2 & -- & -- \\
\hline Nitrate as $\mathrm{N}$ & 10,000 & -- & -- \\
\hline Nitrite & 1,000 & -- & -- \\
\hline Selenium & 50 & -- & -- \\
\hline Silver & -- & -- & 0.1 \\
\hline Sulfate & -- & -- & 250 \\
\hline Thallium & 2 & -- & -- \\
\hline Total dissolved solids & -- & -- & 500 \\
\hline Uranium & 30 & -- & -- \\
\hline Zinc & -- & -- & 5 \\
\hline
\end{tabular}


backhoe-mounted auger. The well was $13 \mathrm{ft}$ deep and extended about $1.5 \mathrm{ft}$ below the bottom of the slag pile. A 2-in. diameter well screen and casing were installed. The well was sampled for field and laboratory chemical analysis. Following sampling, the screen and casing were removed, and the hole was backfilled. Complete field and laboratory analyses are given in table I in the appendix, and selected constituents are summarized in table 10. The water from the slag-pile well had neutral $\mathrm{pH}$ (7.0) and was very low in dissolved solids (specific conductance of $87 \mu \mathrm{S} / \mathrm{cm}$ ). The water sample contained elevated concentrations of aluminum, iron, and manganese relative to the supply well. Elevated concentrations of these metals may be caused by suspended sediment in the water sample or they may indicate that these metals may be leaching from the slag into the groundwater. The results of leaching experiments on the slag samples are described in a separate USGS report (N.M. Piatak and R.R. Seal, II, U.S. Geological Survey, written commun., 2011).

\section{Stream Sites}

Five stream sites (fig. 10) were sampled during base-flow conditions between November 10 and November 14, 2008, to determine if trace-metal or other contamination from the slag piles at Hopewell Furnace was affecting the water quality in French Creek. One site on Baptism Creek (site HF-4) was sampled to indicate background conditions, one site on French Creek (site HF-1) was sampled upstream from Hopewell Furnace, and three sites on French Creek (sites HF-2, HF-3, and HF-5) were sampled downstream from Hopewell Furnace. Samples of water, streambed sediment, and benthic macroinvertebrates were collected and analyzed. An instream habitat assessment was conducted at all sampling locations.

Site HF-1 is on French Creek upstream from the slag piles (fig. 10); much of the flow at this site is from Hopewell Lake, which is upstream from the site (fig. 11). Hopewell Lake is a 62 -acre recreational impoundment with a 25 -ft high dam

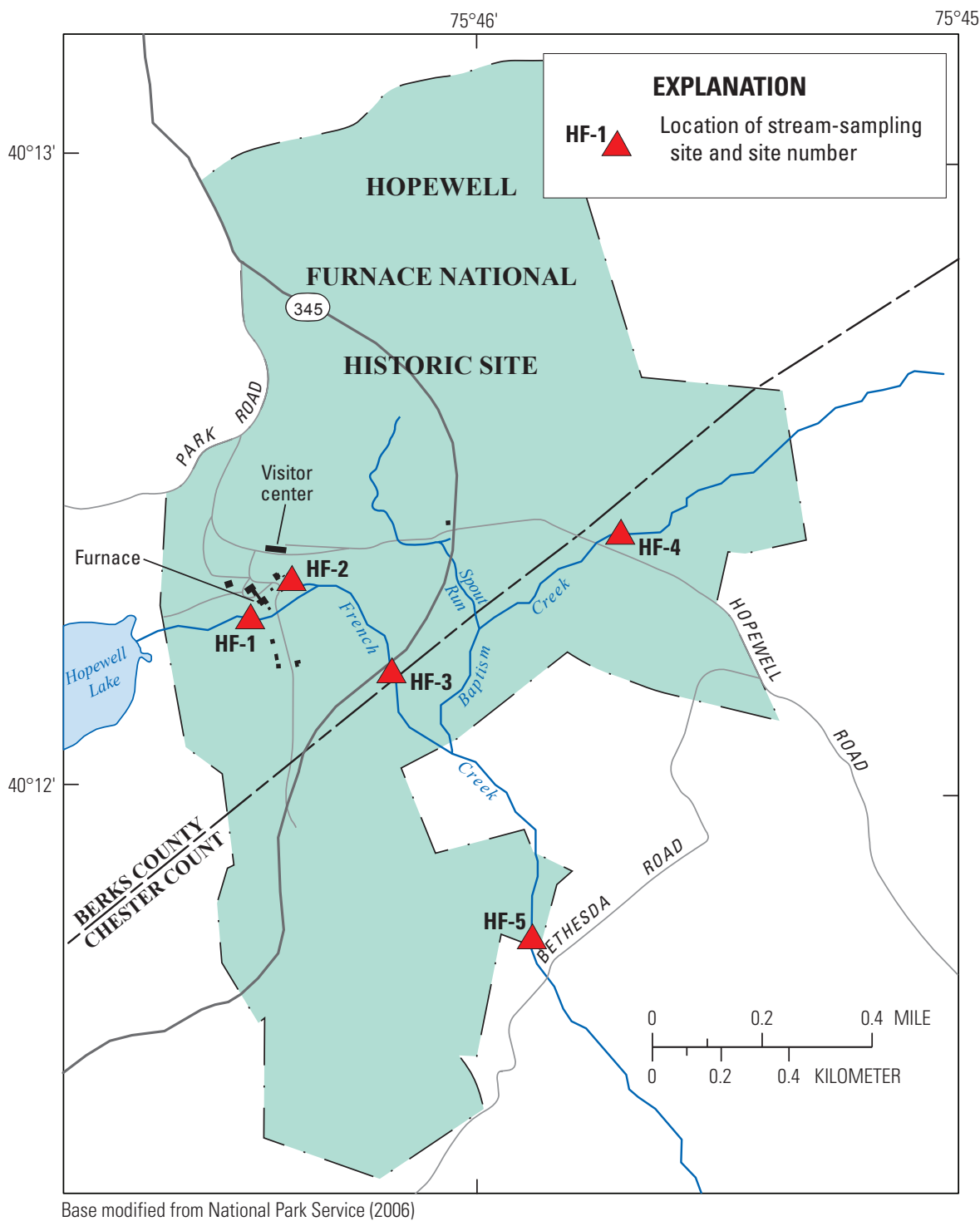

Figure 10. Stream sampling locations at Hopewell Furnace National Historic Site, Pennsylvania. 


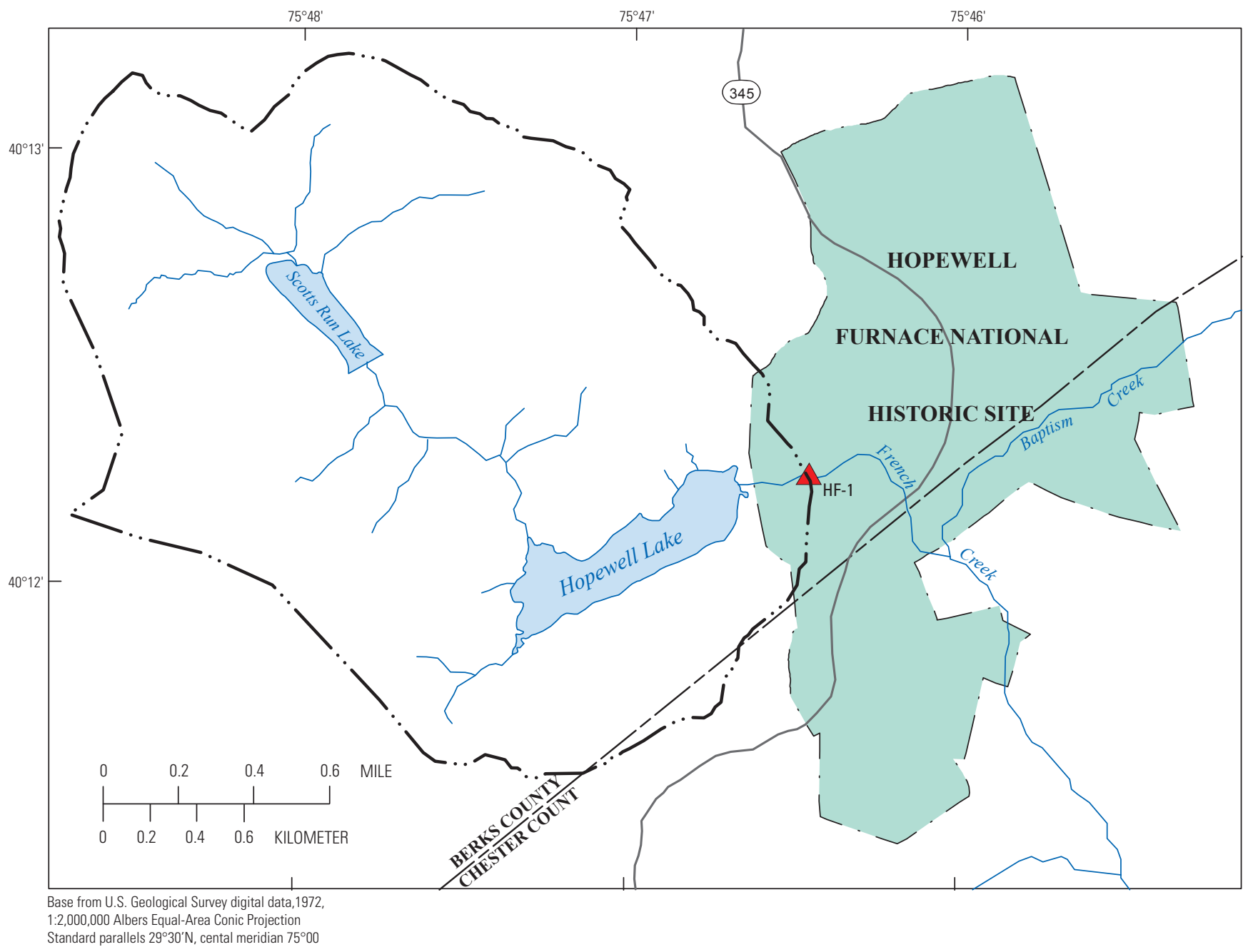

EXPLANATION

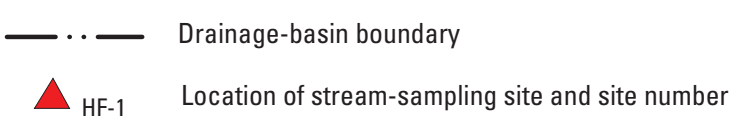

Figure 11. Drainage basin upstream from site HF-1, Hopewell Furnace National Historic Site, Pennsylvania. 
in French Creek State Park. The drainage area above Hopewell Lake is $2.5 \mathrm{mi}^{2}$. The Commonwealth of Pennsylvania classifies Hopewell Lake as a warm-water fishery. Ninety percent of the Hopewell Lake watershed is forested. Scotts Run Lake is upstream from Hopewell Lake. Scotts Run Lake is a 22-acre recreational impoundment in French Creek State Park with a drainage area of $1 \mathrm{mi}^{2}$. The Commonwealth of Pennsylvania classifies Scotts Run Lake as a cold-water fishery.

Site HF-2 is at the downstream end of the tailrace below the furnace water wheel. Water flows underground from the cast house to a point southeast of the barn where it becomes a small tributary to French Creek. The source of water for the millrace is French Creek upstream from the furnace. Streamflow at site HF-2 likely contains some groundwater discharging from the area of slag pile 1. Site HF-3 is on French Creek just upstream from its confluence with Baptism Creek. Site HF-4 is the background site on Baptism Creek. Site HF-5 is on French Creek at the downstream park boundary.

\section{Stream Base Flow}

Surface-water samples were collected at the five stream sites (fig. 10) at base flow when the streamflow was composed of groundwater discharge. However, much of the flow at site HF-1 is outflow from Hopewell Lake. Complete chemical analyses are given in table $\mathrm{J}$ in the appendix, and selected constituents, loads, and yields are summarized in table 12. Samples were collected using standard USGS field collection procedures (U.S. Geological Survey, 1997 to present). All stream reaches were sampled at three locations in the stream cross section by a narrow-mouthed polyethylene bottle placed in the stream (U.S. Geological Survey, 1997 to present). Stream cross-section subsamples were composited in a churn splitter before being processed into bottles for shipment to the USGS laboratory for analysis. Stream discharge and field water-quality characteristics $\mathrm{pH}$, specific conductance, dissolved oxygen, and water temperature were measured with each sample collected. Methods for field measurements were the same as described for groundwater samples. Samples were analyzed for nutrients, major ions, and metals at the USGS laboratory in Denver, Colo. One equipment blank was collected during the sampling period to evaluate potential bias due to contamination. The field blank was processed at a field site by pouring inorganic blank water into the sampling containers and processing it through normal procedures. The blank sample was analyzed for the same constituents as the streamflow samples. All constituents in the blank sample were below the method detection limits, indicating that no bias due to contamination had occurred.

The analytical results (table 12 and appendix table J) indicate low values of specific conductance along with typical $\mathrm{pH}$ values and concentrations of dissolved oxygen near equilibrium with air. Although measured water temperatures were normal for November, the presence of the Hopewell Lake outfall could increase the water temperature downstream from the lake during the summer. Hopewell Lake is a top release lake. During the summer, the temperature of the water at the surface of the lake that is released may be warmer than the background stream water. Low concentrations of dissolved oxygen in the warm water can be stressful to fish and benthicmacroinvertebrate communities. Additional monitoring during the summer months would be needed to evaluate the effects of discharge from the Hopewell Lake outfall on the temperature of French Creek.

The base-flow water samples indicated good overall baseflow surface-water quality. The five sampled sites generally had low concentrations of nutrients and major ions but had elevated concentrations of iron, manganese, and strontium when compared to sites sampled from the adjacent Pickering and Pigeon Creek watersheds (U.S. Geological Survey, 2009). Background site HF-4 generally had the lowest concentrations and yields of constituents. Although the concentrations at the other four sites were higher, all stream-water samples met drinking-water (table 11) and aquatic-life criteria (table 13). Low concentrations of nutrients and major ions at all five sites indicate that measured concentrations can be attributed to general land use and geology and not to point sources. Concentrations of ammonia at sites HF-1 and HF-2 were greater than at background site HF-4, but concentrations decreased to the background concentration at downstream sites HF-3 and HF-5.

Aquatic-life criteria were established to identify concentrations of constituents that may pose a threat to aquatic organisms (U.S. Environmental Protection Agency, 2010b). The criteria categories include criteria maximum concentration (CMC) and criteria continuous concentration (CCC). The $\mathrm{CMC}$ is an estimate of the highest concentration of a constituent in surface water to which an aquatic community can be exposed briefly without resulting in an unacceptable effect. The CCC is an estimate of the highest concentration of a constituent in surface water to which an aquatic community can be exposed indefinitely without resulting in an unacceptable effect. Aquatic-life criteria were created for aluminum, arsenic, cadmium, chromium, iron, lead, nickel, selenium, silver, and zinc. No metal concentrations measured at the five sites exceeded the CMC or CCC (table 13).

The highest concentration of arsenic was measured at site HF-1 $(0.39 \mu \mathrm{g} / \mathrm{L})$. However, arsenic concentrations were similar for all sites with a range of 0.26 to $0.39 \mu \mathrm{g} / \mathrm{L}$. The highest concentrations of cobalt, iron, lead, manganese, strontium, and zinc were measured immediately downstream from Hopewell Furnace at sites HF-2 and HF-3. Although the highest concentrations of aluminum and nickel were measured at background site HF-4, the highest yields of these metals were measured at site HF-1 (table 12). Beryllium, cobalt, lithium, molybdenum, selenium, and uranium were detected at low concentrations. Antimony, cadmium, chromium, copper, silver, and thallium were not detected in any sample (table 12 and appendix table J).

Although the highest concentrations of metals were at sites close to Hopewell Furnace, the samples collected above Hopewell Furnace at site HF-1 and at the most downstream site HF-5 also had concentrations of metals that were higher 


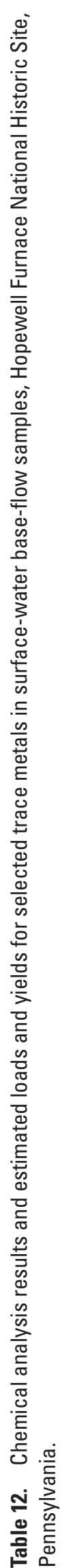
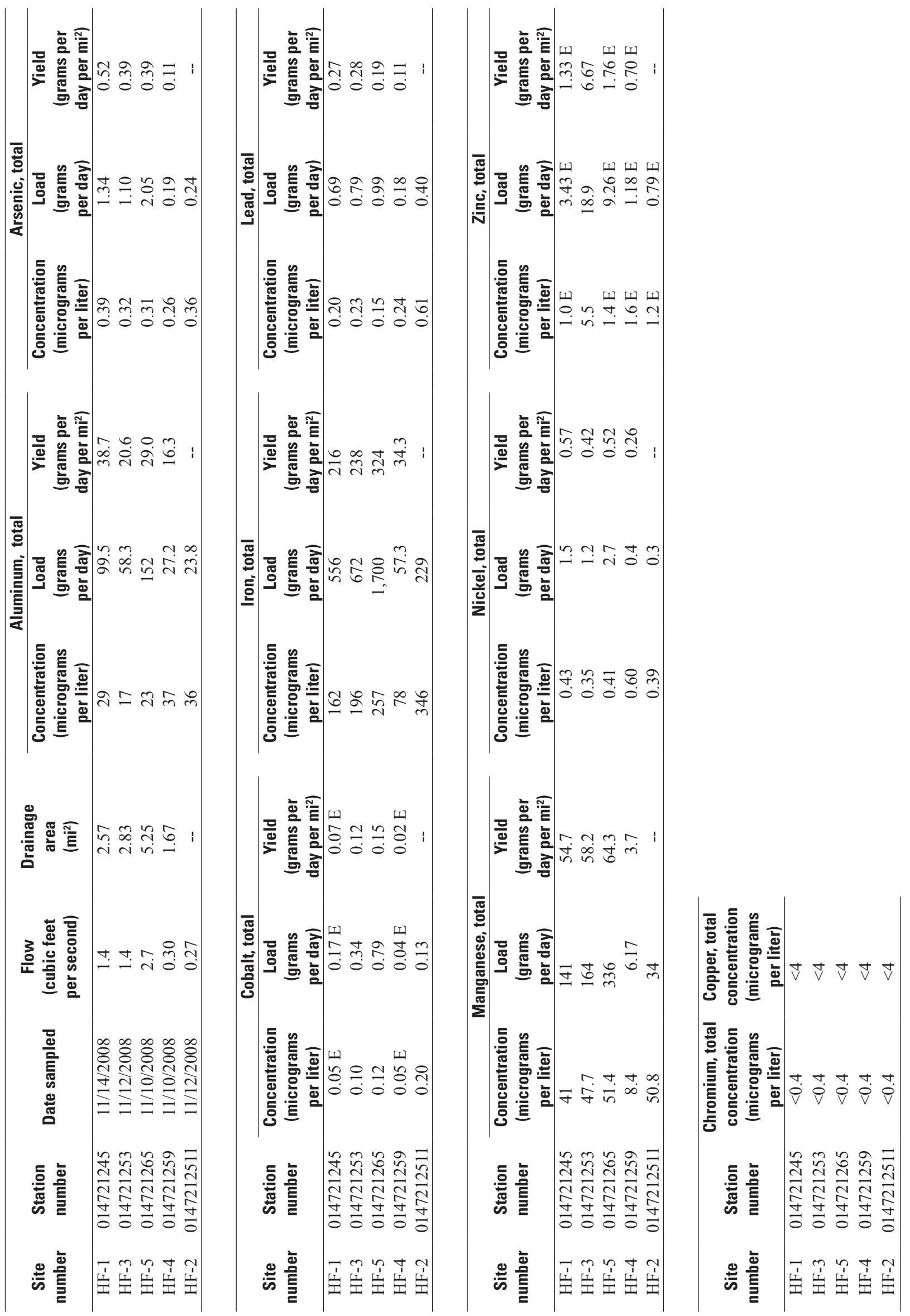
Table 13. Comparison of published criteria maximum and continuous concentrations to measured maximum concentrations of selected trace metals in stream sediment at Hopewell Furnace National Historic Site, Pennsylvania.

[From U.S. Environmental Protection Agency (2010b); concentrations given in micrograms per gram; --, no data; <, less than]

\begin{tabular}{lcccc}
\hline Element & $\begin{array}{c}\text { Criteria } \\
\text { maximum } \\
\text { concentration }\end{array}$ & $\begin{array}{c}\text { Criterion } \\
\text { continuous } \\
\text { concentration }\end{array}$ & $\begin{array}{c}\text { Maximum } \\
\text { concentration } \\
\text { at sampled sites }\end{array}$ & $\begin{array}{c}\text { Maximum } \\
\text { concentration } \\
\text { site location }\end{array}$ \\
\hline Aluminum & 750 & 87 & 37 & HF-4 \\
Arsenic & 340 & 150 & 0.39 & HF-1 \\
Cadmium & 2 & 0.25 & $<0.06$ & All sites \\
Chromium (VI) & 16 & 11 & $<0.04$ & All sites \\
Iron & -- & 1,000 & 346 & HF-2 \\
Lead & 65 & 2.5 & 0.61 & HF-2 \\
Nickel & 470 & 52 & 0.6 & HF-4 \\
Selenium & -- & 5 & 0.14 & HF-2 \\
Silver & 3.2 & -- & $<0.06$ & All sites \\
Zinc & 120 & 120 & 5.5 & HF-3 \\
\hline
\end{tabular}

than background site HF-4. This indicates that the source of the metals is not limited to the area immediately around the Hopewell Furnace slag piles.

USGS has two historical sampling sites near Hopewell Furnace NHS, site 01472126 (French Creek near Trythall, Pa.) and site 01472124 (Hopewell Lake at Hopewell, Pa.). Neither site is currently active. Site 01472124 was sampled twice in 2005 for field determinations, selected nutrients, and selected inorganic constituents. Site 01472126, which is downstream from the park boundary, was sampled annually from 1971 to 1982 and in 2000 for field determinations, nutrients, inorganic constituents, and selected trace constituents. Constituents analyzed and detection limits varied from year to year. Results from these historic samples indicate that concentrations of nutrients, ions, and metals measured prior to 1982 were higher than concentrations measured after 1982 (Moore, 1989; Reif, 1999).

\section{Streambed Sediment}

Streambed-sediment samples were collected at the five stream sites (fig. 10) concurrent with the water samples. At each site, samples were collected from depositional areas within the 100-m stream reach selected for macroinvertebrate sampling. An effort was made to collect the most fine-grained streambed sediments available at each site. Samples were collected manually from the top 6 in. of sediment using a polyethylene scoop and were sieved through a 2-mm polyethylene sieve with native water to remove gravel. Sand, silt, and clay-sized particles that passed through the sieve were collected in a polyethylene basin, homogenized, transferred into glass jars, and kept on ice for shipment to the laboratory. All equipment was washed between each sample with soap,
5 percent hydrochloric acid, and a deionized water rinse. All equipment was then rinsed in native water prior to sampling. Samples were analyzed for metals at the USGS laboratory in Denver, Colo. Samples were analyzed by collision/reaction cell inductively coupled plasma-mass spectrometry (cICP/MS) following digestion in acid. Complete analyses are given in table 14.

Sediment-quality guidelines have been established to identify environmental conditions that may pose a threat to aquatic resources (MacDonald and others, 2000). Concentrations below the probable effects concentration (PEC) are unlikely to cause adverse effects in aquatic communities. Harmful effects in aquatic communities are likely to be observed when concentrations above the PEC are measured. Sediment guidelines have been created for arsenic, cadmium, chromium, copper, lead, mercury, nickel, and zinc. The concentration of copper at site HF-3 was the only metal concentration measured above the PEC (table 15).

PECs have not been established in the United States for aluminum, iron, and manganese. Concentrations of aluminum in streambed-sediment samples from Hopewell Furnace NHS sites are higher and concentrations of iron and manganese are about the same as concentrations in samples from streams in Berks and Chester Counties. The concentrations of aluminum in streambed-sediment samples from Hopewell Furnace NHS sites ranged from 5,700 to $33,500 \mu \mathrm{g} / \mathrm{g}$, and the mean was $14,600 \mu \mathrm{g} / \mathrm{g}$. The range of aluminum concentrations for six samples collected in Berks and Chester Counties during 1972-2000 was 6,800 to $8,700 \mu \mathrm{g} / \mathrm{g}$, and the mean was $7,900 \mu \mathrm{g} / \mathrm{g}$ (USGS National Water Information System data retrieval made on July 26, 2010). The concentrations of iron in streambed-sediment samples from Hopewell Furnace NHS sites ranged from 7,140 to $44,900 \mu \mathrm{g} / \mathrm{g}$, and the mean was 
Table 14. Chemical analysis results for trace metals in streambed sediment samples, Hopewell Furnace National Historic Site, Pennsylvania.

[Laboratory analyses by U.S. Geological Survey National Water Quality Laboratory, Denver, Colo.; concentrations given in micrograms per gram; <, less than; --, no standard]

\begin{tabular}{|c|c|c|c|c|c|c|c|c|}
\hline Site number & Station number & Date sampled & Aluminum & Arsenic & Boron & Cadmium & Chromium & Cobal \\
\hline HF-1 & 014721245 & $11 / 14 / 2008$ & 34,000 & 7.5 & $<5.4$ & 0.54 & 34 & 13.6 \\
\hline HF-2 & 0147212511 & $11 / 12 / 2008$ & 12,000 & 3.3 & 8.8 & 0.22 & 60 & 6 \\
\hline HF-4 & 014721259 & $11 / 10 / 2008$ & 5,700 & 1.5 & 3.8 & 0.14 & 6.3 & 3.3 \\
\hline HF-5 & 014721265 & $11 / 10 / 2008$ & 6,200 & 1.9 & $<5.4$ & 0.14 & 6.5 & 4.2 \\
\hline
\end{tabular}

\begin{tabular}{|c|c|c|c|c|c|c|c|c|}
\hline Site number & Station number & Copper & Iron & Lead & Manganese & Mercury & Nickel & Zinc \\
\hline HF-1 & 014721245 & 31 & 34,000 & 56 & 890 & 0.071 & 28.5 & 150 \\
\hline HF-2 & 0147212511 & 37 & 31,000 & 57 & 730 & 0.032 & 9.9 & 120 \\
\hline HF-4 & 014721259 & 7 & 7,100 & 9 & 210 & 0.017 & 6.1 & 32 \\
\hline HF-5 & 014721265 & 19 & 11,000 & 20 & 330 & 0.031 & 5.9 & 46 \\
\hline
\end{tabular}

${ }^{1}$ MacDonald and others (2000).

Table 15. Comparison of published probable effects concentrations and measured maximum concentrations of selected trace metals in streambed sediment at Hopewell Furnace National Historic Site, Pennsylvania.

[Guidelines from MacDonald and others (2000); concentrations given in micrograms per gram]

\begin{tabular}{lccc}
\hline Element & $\begin{array}{c}\text { Probable } \\
\text { effects } \\
\text { concentration }\end{array}$ & $\begin{array}{c}\text { Maximum } \\
\text { measured } \\
\text { concentration }\end{array}$ & $\begin{array}{c}\text { Maximum } \\
\text { concentration } \\
\text { site location }\end{array}$ \\
\hline Arsenic & 33 & 7.5 & HF-1 \\
Cadmium & 4.98 & 0.54 & HF-1 \\
Chromium & 111 & 59.7 & HF-2 \\
Copper & 149 & 190 & HF-3 \\
Lead & 128 & 86.1 & HF-3 \\
Mercury & 1.06 & 0.13 & HF-3 \\
Nickel & 48.6 & 28.5 & HF-1 \\
Zinc & 459 & 155 & HF-3 \\
\hline
\end{tabular}


$14,200 \mu \mathrm{g} / \mathrm{g}$. The range of iron concentrations for 61 samples collected in Berks and Chester Counties during 1972-2000 was 30 to $40,000 \mu \mathrm{g} / \mathrm{g}$, and the mean was $13,300 \mu \mathrm{g} / \mathrm{g}$ (USGS National Water Information System data retrieval made on July 26, 2010). The concentrations of manganese in streambed-sediment samples from Hopewell Furnace NHS sites ranged from 206 to $2,270 \mu \mathrm{g} / \mathrm{g}$, and the mean was $883 \mu \mathrm{g} / \mathrm{g}$. The range of manganese concentrations for 60 samples collected in Berks and Chester Counties during 1972-2000 was 53 to $1,900 \mu \mathrm{g} / \mathrm{g}$; the mean was $539 \mu \mathrm{g} / \mathrm{g}$ (USGS National Water Information System data retrieval made on July 26, 2010).

Although concentrations of metals in streambed sediment detected at the five sampling sites were below the PEC except for copper at site HF-3 (table 15), background site HF-4 on Baptism Creek had lower concentrations of metals than the other four sites, except for nickel, which was lower at site HF-5. Concentrations of aluminum, cadmium, and nickel were highest at site HF-1 and generally decreased in concentration downstream. This indicates the source of these metals is upstream from site HF-1 and may be related to discharge from Hopewell Lake. Oxidizing conditions or elevated $\mathrm{pH}$ could promote the formation of iron oxide and aluminum oxide coatings and adsorption of metals, effectively concentrating these constituents locally. The concentration of chromium was highest in sediment from site HF-2. The highest concentrations of arsenic, boron, cobalt, copper, iron, lead, manganese, mercury, and zinc were detected at site HF-3 below Hopewell Furnace. This indicates that the source of these metals may be in Hopewell Furnace NHS between sites HF-1 and HF-3.

\section{Benthic Macroinvertebrates}

Benthic-macroinvertebrate samples were collected at the five stream sites (fig. 10) concurrent with the water and sediment samples. Benthic-macroinvertebrate samples were collected following the USEPA Rapid Bioassessment Protocols
(RBP) (Barbour and others, 1999). The samples were collected using a 500-micron D-frame net. Three $1-\mathrm{m}^{2}$ kick samples were collected at each site within a $100-\mathrm{m}$ reach and composited. The samples were sieved and rinsed using a Standard No. 30 sieve to remove fine sediments. The samples were preserved with 95-percent ethanol in the field and returned to the laboratory for sorting and identification.

In the laboratory, composited samples were subsampled (300 organisms) using methods described in the USEPA RBP methodology (Barbour and others, 1999). All sorted organisms were identified to the lowest practical taxonomic level (genus) except for midge larve (chironomidae) and worms (oligocheatae), which were identified to the family level. Complete counts are given in table $\mathrm{K}$ in the appendix and summarized in table 16. In addition to benthic-macroinvertebrate identifications, biometric indices ("metrics") were calculated for each 300-organism sample. Many of the metrics rely on pollution tolerance values (PTV) that are assigned to each organism on the basis of its ability to survive in degraded environments. PTVs range from 0 (pollution sensitive) to 10 (pollution tolerant).

Calculated metrics include:

1. Total Taxa Richness, which is a measurement of the total number of taxa (taxonomic distinct organism) present. Higher taxa richness generally reflects a healthier macroinvertebrate community.

2. Ephemeroptera, Plecoptera, Trichoptera (EPT) Taxa Richness, which is a count of the number of taxa belonging to the orders Ephemeroptera (mayflies), Plecoptera (stoneflies), and Trichoptera (caddisflies). Only EPT taxa with PTVs between 0 and 4 are counted. EPT taxa richness generally decreases with increasing ecosystem stress because of the loss of these pollution-sensitive taxa.

3. Hilsenhoff Biotic Index (HBI), which summarizes the overall pollution tolerance of the benthic-macroinverte-

Table 16. Biometrics for benthic macroinvertebrates sampled at Hopewell Furnace National Historic Site, Pennsylvania.

[300 organism subsamples; HBI, Hilsenhoff's biotic index; EPT, Ephemeroptera, Plecoptera, and Trichoptera; PTV, pollution tolerant value]

\begin{tabular}{lccccc}
\hline Station number & 014721245 & 0147212511 & 0147212511 & 014721253 & 014721259 \\
Site number & HF-1 & HF-2 & HF-2 replicate & HF-3 & HF-4 \\
Date sampled & $11 / 14 / 08$ & $11 / 12 / 08$ & $11 / 12 / 08$ & $11 / 12 / 08$ & $11 / 10 / 08$ \\
Grids & 8 & 9 & 10 & 10 & 12 HF-5 \\
Total count & 317 & 336 & 303 & 302 & 330 \\
Total Taxa Richness & 21 & 26 & 30 & 25 & 33 \\
EPT Taxa Richness (0-4 PTV) & 3 & 3 & 4 & 8 & 17 \\
HBI & 5.27 & 5.85 & 5.97 & 5.46 & 4.05 \\
Beck's Index & 1 & 0 & 6 & 5 & 19 \\
Shannon Diversity & 1.6 & 1.9 & 1.8 & 2.0 & 5.26 \\
Percent Sensitive Individuals (0-3 PTV) & 21.77 & 8.93 & 4.95 & 14.9 & 2.3 \\
\hline
\end{tabular}


brate community. The range of values is from 0 to 10 ; values generally increase with increasing ecosystem stress, reflecting increased dominance of pollution-tolerant organisms.

4. Beck's Index (version 3), which is a weighted count of taxa with PTVs of 0,1 , or 2 . Values will generally decrease with increasing ecosystem stress because of the loss of pollution-sensitive taxa.

5. Percent Sensitive Individuals (PTV $=0$ to 3 ), which is a community composition and tolerance metric that is based on the percentage of individuals with PTVs between 0 and 3 . This metric will generally decrease with increasing ecosystem stress because of the loss of pollution-sensitive taxa.

6. Shannon Diversity, which is a community-composition metric that measures taxonomic richness and evenness of individuals across taxa. This metric will generally decrease with increasing ecosystem stress because of the loss of pollution-sensitive taxa and increasing dominance of a few pollution-tolerant taxa.

Quality control for the benthic-macroinvertebrate samples involved the processing of a replicate subsample from the sample collected at site HF-2. The replicate invertebrate sample indicated that most of the biological metrics for the sample were within 15 percent of the original sample with the exception of percent sensitive individuals and Beck's index. This was due to the presence in the replicate sample of a few individuals with low pollution tolerance values. The difference between the replicate and original sample does not alter the overall assessment of the site and is consistent with the natural variability of biological samples and sample processing.

The benthic-macroinvertebrate communities at the French Creek sites (HF-1, HF-2, HF-3, and HF-5) were similar to each other but differed greatly from the benthic-macroinvertebrate community at the Baptism Creek background site HF-4. Pollution-sensitive organisms dominated the benthicmacroinvertebrate community at site HF-4. When compared to the other four sites, site HF-4 had the lowest HBI score (4.05) and highest values for total taxa richness (33), EPT taxa richness (17), Beck's Index (19), Shannon Diversity (2.3), and percent sensitive individuals (46.67) (table 16). All the metric values indicated a diverse community low in pollution-tolerant taxa and high in pollution-sensitive taxa. The benthic-macroinvertebrate communities at the French Creek sites contained fewer taxa and were dominated by pollution-tolerant taxa. This is an indication that chemical and (or) physical conditions in French Creek near Hopewell Furnace are degraded compared to the background site on Baptism Creek.

Site HF-1 was immediately downstream from the Hopewell Lake outfall and upstream from Hopewell Furnace and the slag piles. Site HF-1 was dominated by Hydropsychid caddisflies (PTV = 5-6), contained numerous non-insect taxa, and had a Beck's Index value of 1 . The metrics indicated a disturbed macroinvertebrate community. Sites HF-2 and HF-3 had increased numbers of EPT taxa but also had increased HBI values when compared to site HF-1. This was due to a decrease in dominance in Hydropsychid caddisflies and an increase in midges $(\mathrm{PTV}=6)$. Sites HF-2 and HF-3 also had relatively few pollution-sensitive taxa and had metric values that indicated a disturbed community. Site HF-5 is at the park boundary and is the most-downstream site sampled. Decreased HBI and increased values for percent sensitive individuals and Shannon Diversity indicate a slight improvement over the upstream sites, but site HF-5 is still degraded when compared to background site HF-4.

The benthic-macroinvertebrate sampling indicated that all four sites sampled on French Creek had disturbed communities when compared to background site HF-4 on Baptism Creek. The French Creek sites were dominated by pollutiontolerant taxa and had relatively few pollution-sensitive taxa. There were small differences in community structure and metric values, but the overall evaluation indicated degraded conditions in French Creek near Hopewell Furnace.

\section{Habitat Evaluations}

Habitat evaluations (table 17) were performed to assess the structure of the surrounding physical habitat that influences the quality of the water resources and the condition of the benthic-macroinvertebrate community. Habitat parameters pertinent to the assessment of habitat quality include the variety and quality of the substrate, channel morphology, bank structure, and riparian areas. Barbour and others (1999) described habitat-assessment criteria in detail. Ten parameters were evaluated and rated on a numerical scale of 0 to 20 for each sampling reach with higher scores indicating improved habitat quality. Each category is divided into four groups: optimal, suboptimal, marginal, and poor.

Habitat scores at the five sites sampled ranged from 113 to 160 (table 17). Background site HF-4 on Baptism Creek had a score of 151 with 7 of the 10 categories ranked in the optimal range. The stream in this reach is $2.4 \mathrm{~m}$ wide and had bottom substrate composed of a mix of cobbles, gravel, and sand. The reach was a mixture of riffles, runs, and pools. The riparian area was a mix of woods and pasture. The three parameters that scored in the suboptimal range were depth regime, sediment deposition, and bank stability. Baptism Creek is a small stream and had no deep sections in the sampling reach, which caused the lower depth-regime score. The scores for sediment deposition and bank stability were related to minor erosion and deposition in the sampling reach.

Site HF-1 is on French Creek downstream from Hopewell Lake and upstream from Hopewell Furnace. The stream in this reach is $2.5 \mathrm{~m}$ wide and had bottom substrate composed of a mix of boulders, cobbles, and gravel. The reach was a mixture of riffles, runs, and pools. The riparian area was heavily wooded and undisturbed. This site had a habitat score of 160, the highest score of the five sites. Eight of the 10 categories 
Table 17. Results of habitat survey conducted at Hopewell Furnace National Historic Site, Pennsylvania.

[LB, left bank; RB, right bank]

\begin{tabular}{|c|c|c|c|c|c|}
\hline Station number & 014721245 & 0147212511 & 014721253 & 014721259 & 014721265 \\
\hline Site number & HF-1 & HF-2 & HF-3 & HF-4 & HF-5 \\
\hline Date & $11 / 14 / 08$ & $11 / 12 / 08$ & $11 / 12 / 08$ & $11 / 10 / 08$ & $11 / 10 / 08$ \\
\hline & & itat parameter & & & \\
\hline 1. Epifaunal substrate/available cover & 17 & 7 & 9 & 16 & 7 \\
\hline 2. Embeddedness & 14 & 12 & 13 & 15 & 9 \\
\hline 3. Velocity/depth regime & 15 & 9 & 11 & 10 & 11 \\
\hline 4. Sediment deposition & 13 & 10 & 7 & 13 & 8 \\
\hline 5. Channel flow status & 17 & 16 & 16 & 16 & 18 \\
\hline 6. Channel alteration & 15 & 15 & 16 & 18 & 18 \\
\hline 7. Frequency of riffles (or bends) & 16 & 7 & 10 & 16 & 6 \\
\hline \multicolumn{6}{|l|}{ 8. Bank stability } \\
\hline LB & 9 & 8 & 6 & 7 & 6 \\
\hline RB & 8 & 8 & 6 & 7 & 6 \\
\hline \multicolumn{6}{|l|}{ 9. Vegetative protection } \\
\hline LB & 9 & 5 & 7 & 8 & 7 \\
\hline RB & 9 & 5 & 7 & 8 & 7 \\
\hline \multicolumn{6}{|l|}{ 10. Riparian vegetative zone width } \\
\hline LB & 9 & 6 & 8 & 9 & 10 \\
\hline RB & 9 & 5 & 8 & 8 & 10 \\
\hline TOTAL & 160 & 113 & 124 & 151 & 123 \\
\hline
\end{tabular}

were ranked in the optimal range. This site had excellent habitat quality with complete canopy cover, stable varied substrate, and stable banks. The site had some minor sedimentation that caused the embeddedness and sediment deposition scores to be ranked suboptimal.

The stream at site HF-2 was $1.8 \mathrm{~m}$ wide and had bottom substrate composed of a mix of sand and gravel with a few cobbles. The reach was mostly run areas with a few sandbottom riffles. The riparian area was pasture with few trees. The banks were grass covered, and the stream was open to the sunlight. This site had a habitat score of 113, the lowest of the five sites. Eight of the 10 categories were ranked below optimal. The major habitat problems at site HF-2 include unstable substrate, pasture riparian area, and heavy sedimentation.

Site HF-3 is on French Creek below Hopewell Furnace. The stream in this reach is $3.9 \mathrm{~m}$ wide and had bottom substrate composed of a mix of cobbles, gravel, and sand. The reach was mostly pool with a few small cobble-bottomed riffles. The riparian area was heavily wooded and undisturbed below the bridge at State Route 345. This site had a habitat score of 124 with 8 of the 10 categories ranked below optimal.
The major habitat problems at site HF-3 include unstable substrate and heavy sedimentation.

Site HF-5 is on French Creek at the downstream park boundary below the confluence with Baptism Creek. The stream in this reach is $3.5 \mathrm{~m}$ wide and had bottom substrate composed of sand and gravel. The reach was mostly pool and run areas with a few small riffles. There were few cobbles exposed on the stream bottom. The riparian area was heavily wooded and undisturbed. This site had a habitat score of 123 with 8 of the 10 categories ranked below optimal. The major habitat problems at site HF-5 include unstable substrate and heavy sedimentation.

The overall habitat quality at the five sites sampled varied from good to marginal. The habitat at sites HF-1 and HF-4 was sufficient to support a diverse benthic-macroinvertebrate community. These sites featured wooded riparian areas, stable bank and stream-bottom substrate, and minor erosion and sedimentation issues. The overall habitat quality at sites HF-2, HF-3, and HF-5 was marginal. The lack of stable bottom substrate and heavy sand and gravel deposition may limit the diversity of the benthic-macroinvertebrate community at these sites. 


\section{Statistical Summary of Selected Metals}

Minimum, maximum, mean, and median concentrations of selected metals for all media sampled are summarized in table 18. Arsenic was present in ore samples at a mean concentration of $28.4 \mathrm{ppm}$ (table 18). Arsenic appears to be concentrated in cast iron furnace products (mean concentration of $499 \mathrm{ppm})$. The mean arsenic concentrations in soil near the furnace (5.5 ppm), in samples from slag pile 1 (4.1 ppm), and in streambed sediment (4.4 ppm) were about the same as the mean concentration of background soil samples (5 ppm) and the mean concentration ( $4.8 \mathrm{ppm})$ for soil in the eastern United States. Concentrations of arsenic in groundwater and stream base flow were less than $0.004 \mathrm{ppm}$.

The mean concentration of chromium was $4.5 \mathrm{ppm}$ for ore samples, $15.8 \mathrm{ppm}$ for samples from slag pile 1 , and 25 ppm for streambed sediments (table 18). The mean chromium concentration in soil near the furnace $(51.3 \mathrm{ppm})$ was slightly higher than the mean concentration of background soil samples $(28 \mathrm{ppm})$ and the mean concentration ( $33 \mathrm{ppm})$ for soil in the eastern United States. Chromium concentrations were less than the detection limit for cast iron furnace products and stream base flow. Concentrations of chromium in groundwater were less than $0.002 \mathrm{ppm}$.

Cobalt was present in ore samples at a mean concentration of $74.8 \mathrm{ppm}$ (table 18). The mean cobalt concentration in soil near the furnace (16.1 ppm) was about the same as the mean concentration of background soil samples (15.3 ppm), both of which were slightly higher than the mean concentration $(5.9 \mathrm{ppm})$ for soil in the eastern United States (table 4). The elevated concentrations of cobalt in cast iron analyzed by X-ray fluorescence spectroscopy was likely caused by interference from high concentrations of iron. Cobalt was detectable in the stoves but was not quantifiable. The mean cobalt concentration was $8.6 \mathrm{ppm}$ in samples from slag pile 1 and $9.4 \mathrm{ppm}$ in streambed sediments. Concentrations of cobalt in groundwater and stream base flow were less than $0.004 \mathrm{ppm}$.

Copper was present in ore samples at a median concentration of 9,080 ppm (table 18). Copper appears to be concentrated in cast iron furnace products (mean of $1,860 \mathrm{ppm}$ and median of 2,000 ppm). The mean copper concentrations of samples from slag pile 1 (41.2 ppm), from soil near the furnace (53.9 ppm), and from streambed sediment (56.6 ppm) were similar and were slightly higher than the mean concentration of background soil samples $(20.7 \mathrm{ppm})$ and the mean concentration (13 ppm) for soil in the eastern United States. Copper was not detected in stream base flow and was less than $0.004 \mathrm{ppm}$ in groundwater.

Iron was the major constituent of ore (concentrations greater than 150,000 ppm) (table 18). The median iron concentrations in soil near the furnace $(39,300 \mathrm{ppm})$ and in samples from slag pile $1(49,200 \mathrm{ppm})$ were greater than the median concentration of background soil samples $(29,000 \mathrm{ppm})$ and the mean concentration $(14,000 \mathrm{ppm})$ for soil in the eastern United States. The median iron concentration was 31,100 ppm for streambed sediment. The concentration of iron in the water sample from the well drilled into the slag pile (1.74 ppm) was substantially higher than the concentration in the water sample from the supply well $(0.032 \mathrm{ppm})$. The iron concentration was less than $0.4 \mathrm{ppm}$ in stream base flow.

Lead was present in ore samples at a mean concentration of $184 \mathrm{ppm}$ (table 18). Lead appears to be concentrated in cast iron furnace products (mean of $588 \mathrm{ppm}$ ). The mean lead concentrations in soil near the furnace (137 ppm), in samples from slag pile 1 (37.3 ppm), and in streambed sediment (45.6 ppm) were greater than the mean concentration of background soil samples (18.1 ppm) and the mean concentration (14 ppm) for soil in the eastern United States. Concentrations of lead in groundwater and stream base flow were less than $0.02 \mathrm{ppm}$.

Manganese was present in ore samples at a mean concentration of 1,550 ppm (table 18). Manganese was detected in only three of the eight cast iron stoves sampled. Manganese appears to be concentrated in slag (mean of 4,410 ppm). The mean manganese concentration in soil near the furnace $(1,190 \mathrm{ppm})$ was about the same as the mean concentration of background soil samples (1,340 ppm); mean soil concentrations were substantially higher than the mean concentration $(260 \mathrm{ppm})$ for soil in the eastern United States. The concentration of manganese in the water sample from the well drilled into the slag pile $(2.43 \mathrm{ppm})$ was substantially higher than the concentration in the supply well $(0.0023 \mathrm{ppm})$. The mean manganese concentration was $883 \mathrm{ppm}$ in streambed sediment and $0.04 \mathrm{ppm}$ in stream base flow.

Nickel was present in ore samples at a mean concentration of $76.5 \mathrm{ppm}$ (table 18). Nickel was not detected in cast iron furnace products. The mean nickel concentrations in soil near the furnace (29.1 ppm), in samples from slag pile $1(7.3 \mathrm{ppm})$, and in streambed sediment (14.6 ppm) were about the same as the mean concentration of background soil samples (21.2 ppm) and the mean concentration (11 ppm) for soil in the eastern United States. Concentrations of nickel in groundwater and stream base flow were less than $0.003 \mathrm{ppm}$.

Zinc was present in ore samples at a mean concentration of $726 \mathrm{ppm}$ (table 18). Zinc appears to be concentrated in cast iron furnace products (mean of 1,280 ppm). The mean zinc concentrations in soil near the furnace $(173 \mathrm{ppm})$, in samples from slag pile 1 (77.7 ppm), and in streambed sediment (101 ppm) were greater than the mean concentration of background soil samples $(46.6 \mathrm{ppm})$ and the mean concentration (40 ppm) for soil in the eastern United States. Concentrations of zinc in groundwater and stream base flow were less than $0.02 \mathrm{ppm}$. 


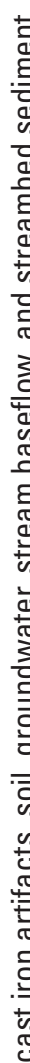

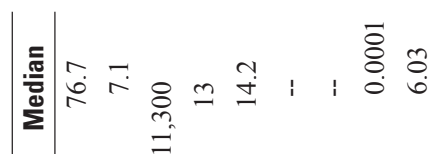

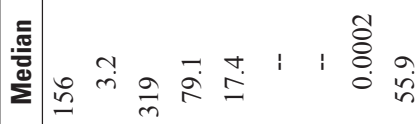

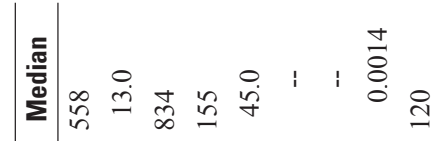

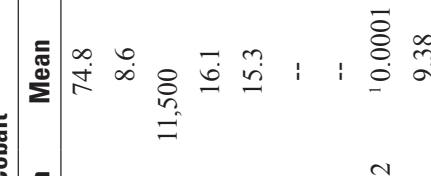

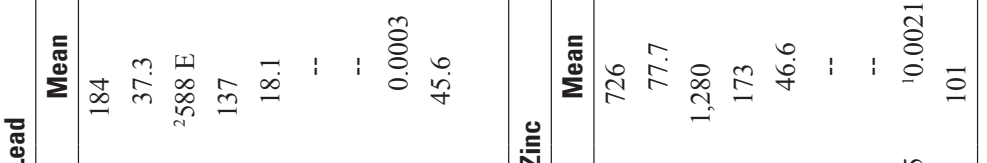

卷

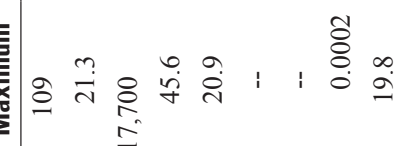

폄

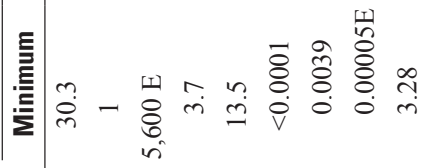

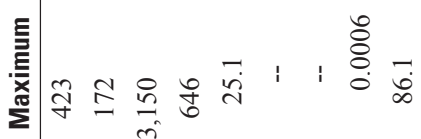

宗

畩

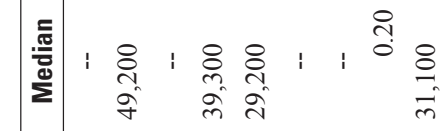

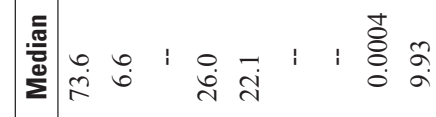

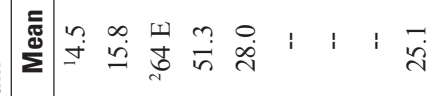

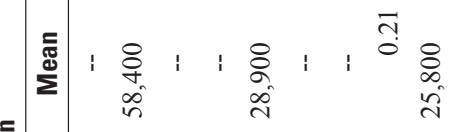

흔

흐

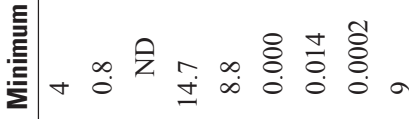

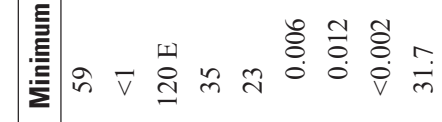

ह 8 \& \& \&,

离

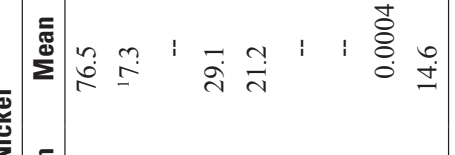

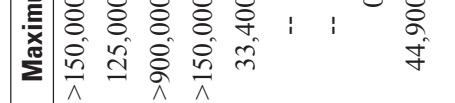

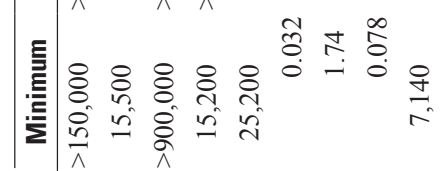

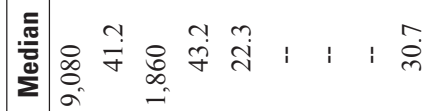

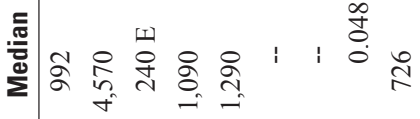

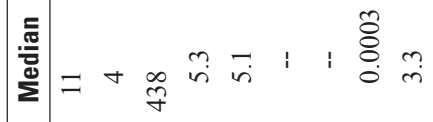

ப

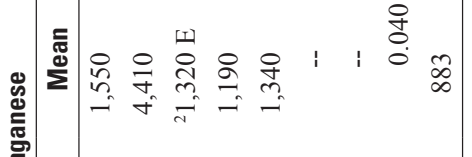

흠

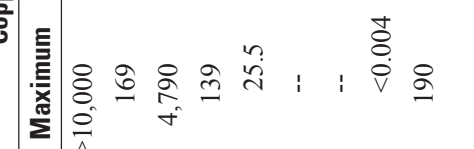

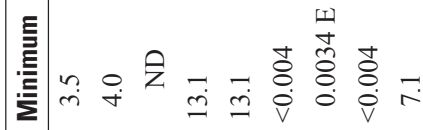

产

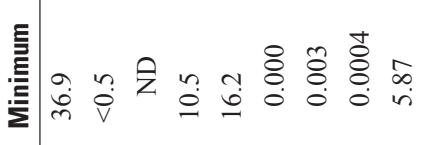

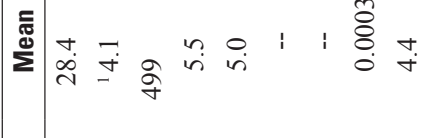

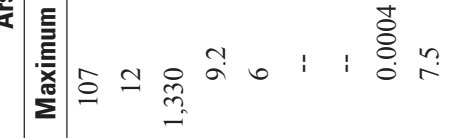

言

$=n \subseteq \infty \underset{+}{\infty} \infty--n n$

$=n \bigcirc \underset{+}{\infty} \underset{\sim}{\infty}--n n$
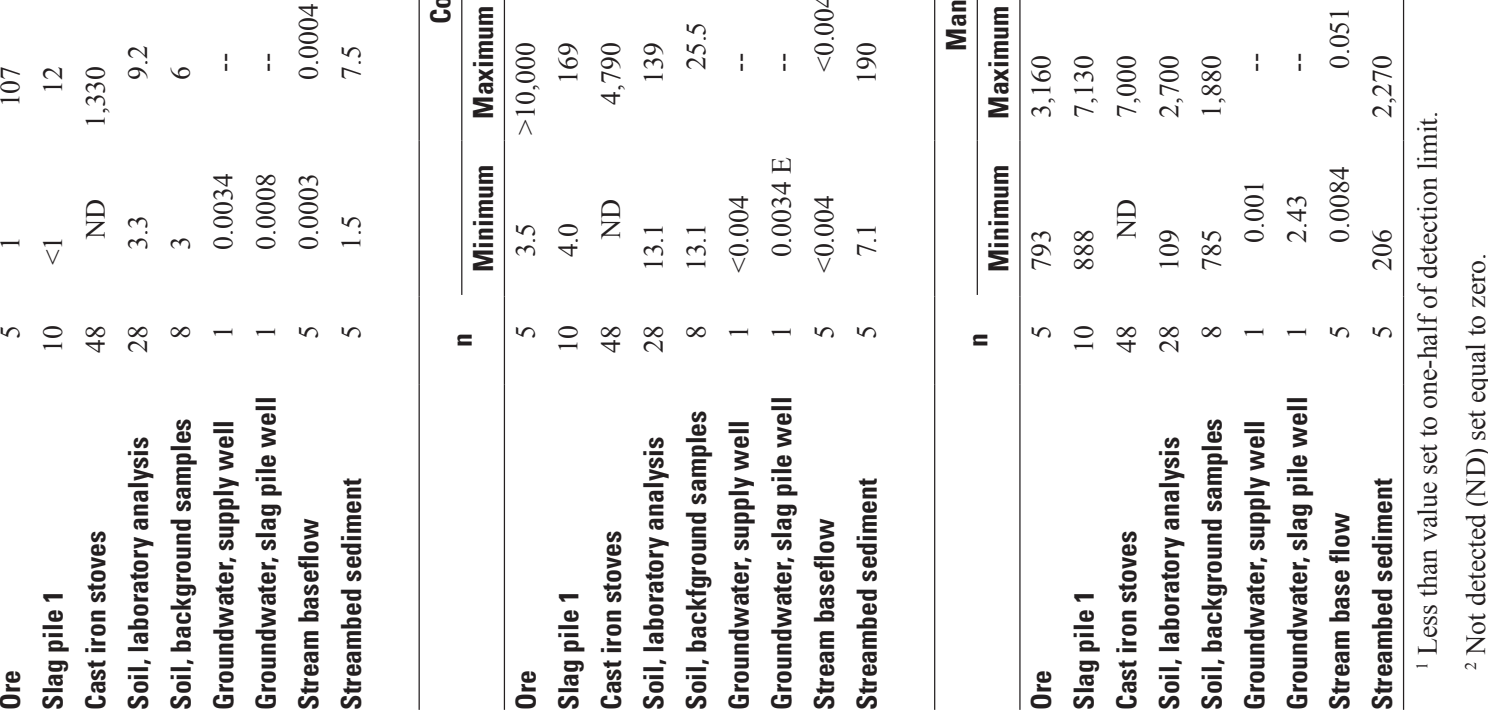


\section{Summary and Conclusions}

The 848-acre Hopewell Furnace National Historic Site (NHS) is one of the finest examples of a rural American 19thcentury iron plantation. Hopewell Furnace was in operation for 113 years (1771-1883). Hopewell Furnace NHS, located approximately $50 \mathrm{mi}$ northwest of Philadelphia, straddles the Berks-Chester County border in southeastern Pennsylvania. The purpose of this study by the U.S. Geological Survey, in cooperation with the National Park Service, was to determine the distribution of trace metals in Hopewell Furnace NHS related to iron smelting. Local mines supplied the iron ore used at Hopewell Furnace. These ore deposits contained abundant magnetite and accessory sulfide minerals enriched in arsenic, cobalt, copper, and other metals.

Trace metals from ore smelted at Hopewell Furnace followed several pathways. During the smelting process, trace metals were (1) volatilized as air emissions from the furnace, (2) combined with slag, or (3) incorporated into the cast iron products of the furnace. Volatilized metals likely were deposited on the land and other surfaces downwind from the furnace. Travel distance may have been short because of the low height ( $32 \mathrm{ft}$ ) of the furnace stack. Metals deposited on the land may have been washed into the surface-water system, adsorbed onto soil, or taken up by plants and animals. Erosion would move some of the soil and plant matter into the stream system where it would become stream sediment. Trace metals present in slag, which is a glass-like waste material deposited near the furnace, could be immobile or, during physical and chemical weathering, could have leached into the soil or groundwater and surface-water system. Shallow, local groundwater discharges directly to French Creek.

Ore, slag, cast iron furnace products, soil, groundwater, stream base flow, and streambed sediment were sampled and analyzed for trace-element concentrations. In addition, benthic macroinvertebrates were analyzed from the five stream sites where surface-water base flow and streambed-sediment samples were collected.

Arsenic, copper, lead, zinc, and possibly cobalt were incorporated into the cast iron produced by Hopewell Furnace. Manganese was concentrated in slag along with iron, nickel, and zinc. The soil near the furnace had elevated concentrations of chromium, copper, iron, lead, and zinc compared to background soil concentrations.

The base-flow surface-water samples indicated good overall quality. The five sampled sites generally had low concentrations of nutrients and major ions but had elevated concentrations of iron, manganese, and strontium when compared to sites sampled in adjacent watersheds. Background site HF-4 generally had the lowest concentrations and yields of constituents. Low concentrations of nutrients and major ions at all five sites indicate that measured concentrations can be attributed to general land use and geology and not to point sources.

The highest concentration and yield of arsenic was measured at site HF-1; however, arsenic concentrations were similar for all sites with a range of 0.26 to $0.39 \mu \mathrm{g} / \mathrm{L}$. The highest concentrations of cobalt, iron, lead, manganese, strontium, and zinc were measured immediately downstream from Hopewell Furnace at sites HF-2 and HF-3. Although the highest concentrations of aluminum and nickel were measured at background site HF-4, the highest yields of these metals were measured at site HF-1.

Streambed-sediment sampling results indicated higher concentrations of all metals except nickel at sites on French Creek compared to the background site on Baptism Creek. Although metal concentrations in streambed sediments were higher than the background site, all concentrations measured were below the probable effects limits except for copper at site HF-3. Concentrations of aluminum, cadmium, and nickel were highest in sediment at site HF-1 and generally decreased in concentration downstream, which indicates the source of these metals is upstream from site HF-1 and may be related to discharge from Hopewell Lake. The highest concentrations of arsenic, boron, cobalt, copper, iron, lead, manganese, mercury, and zinc were detected at site HF-3 below Hopewell Furnace, which indicates that the source of these metals may be in Hopewell Furnace NHS between sites HF-1 and HF-3.

The invertebrate community at the background site on Baptism Creek was dominated by pollution-sensitive taxa indicating a healthy, diverse benthic-macroinvertebrate community. Benthic-macroinvertebrate communities at sampling sites on French Creek indicated that the overall stream quality immediately above and below Hopewell Furnace NHS was degraded. The benthic-macroinvertebrate community sampled at the sites on French Creek indicated disturbed communities when compared to the background site on Baptism Creek. The benthic-macroinvertebrate communities were dominated by pollution-tolerant taxa, and taxa were less diverse than the background site.

Habitat conditions at upstream site HF-1 were good but were degraded at downstream sites HF-2, HF-3, and HF-5. The major habitat issues at these sites were related to a lack of stable substrate, erosion, and deposition. Water quality and streambed-sediment quality do not indicate that the degraded benthic-macroinvertebrate communities are the result of poor water quality. Habitat conditions (erosion and sedimentation) and physical alterations (water temperature) from the outfall of Hopewell Lake are the most likely cause of the impaired communities.

In conclusion, soil samples collected from the Hopewell Furnace NHS and analyzed in the laboratory met Pennsylvania Department of Environmental Protection standards for nonresidential use. Groundwater samples from the park supply well met U.S. Environmental Protection Agency drinkingwater standards. Concentrations of metals in surface-water base flow at the five stream sampling sites were below criteria continuous concentrations for protection of aquatic organisms. Concentrations of metals in sediment at the five stream sampling sites were below probable effects level guidelines for protection of aquatic organisms except for copper at site HF-3. 


\section{Acknowledgments}

Nadine Piatak, Jane Hammarstrom, and Robert Seal of the USGS and Denise Levitan of Virginia Polytechnic Institute collected the slag samples. Soil and groundwater sampling was done with assistance from Arthur Lilienthal of the USGS. Martin Helmke and Cynthia Hall of West Chester University and Michael Degnan of the USGS conducted the soil and cast iron artifact analysis by X-ray fluorescence spectroscopy. Gregory Kolous of Kutztown University provided the ore samples from the Jones mine.

\section{References Cited}

Agency for Toxic Substances and Disease Registry, 2004, Cobalt: U.S. Department of Health and Human Services, Public Health Service Fact Sheet, 2 p.

Agency for Toxic Substances and Disease Registry, 2007, Arsenic: U.S. Department of Health and Human Services, Public Health Service Fact Sheet, 2 p.

Barbour, M.T., Gerritsen, J., Snyder, B.D., and Stribling, J.B., 1999, Rapid bioassessment protocols for use in streams and wadeable rivers-Periphyton, benthic-macroinvertebrates, and fish (2d ed.): U.S. Environmental Protection Agency, Office of Water, report EPA 841-B-99-002, 202 p.

Chalfant, B., 2007, A benthic index of biotic integrity for wadeable freestone streams in Pennsylvania: Pennsylvania Department of Environmental Protection, 157 p.

Glaser, Leah, 2005, Hopewell Furnace National Historic Site Administrative History: National Park Service, 341 p.

Hopewell Furnace National Historic Site, 2007, Foundation for planning and management: $43 \mathrm{p}$.

Kurjack, D.C., 1954, Hopewell Village National Historic Site Pennsylvania (now Hopewell Furnace): Washington, D.C., National Park Service Historical Handbook Series No. 8, accessed on December 16, 2009, at http://www.nps.gov/ history/history/online_books/hh/8/hh8toc.htm.

MacDonald, D.D., Ingersoll, C.G., and Berger, T.A., 2000, Development and evaluation of consensus-based sediment quality guidelines for freshwater ecosystems: Archives of Environmental Contamination and Toxicology, v. 39, p. $20-31$.

Moore, C.R., 1989, Physical, chemical, and biological data for selected streams in Chester County, Pennsylvania, 1969-80: U.S. Geological Survey Open-File Report 85-686, 289 p.

National Park Service, 1983, Hopewell Furnace: National Park Service Handbook 124, 96 p.
National Park Service, 2006, Hopewell National Historic Site map, accessed July 25, 2006, at http://www.nps.gov/hofu/ ppmaps/hofumap.pdf.

National Park Service, 2009, Conservation and outdoor recreation Pennsylvania segments, accessed December 16, 2009, at http://www.nps.gov/ncrc/programs/rtca/nri/states/ pa.html.

Pennsylvania Department of Environmental Protection, 2011, Postremediation care attainment, table 4, mediumspecific concentrations (MSCs) for inorganic regulated substances in soil, direct contact values: accessed March 10, 2011 at http://files.dep.state.pa.us/LocalGovt/OCRLGS/ LocalGovtPortalFiles/SWH\%20Tables\%202011/Table\%20 4a\%202011.pdf.

Pennsylvania State University, 2009, Reading Regional Airport: Pennsylvania State Climatologist, Pennsylvania wind roses, accessed December 7, 2009, at http://climate.met. psu.edu/features/PA_WIND_ROSES/RDGwindrose.php.

Reif, A.G., 1999, Physical, chemical, and biological data for selected streams in Chester County, Pennsylvania, 198194: U.S. Geological Survey Open-File Report 99-216, $607 \mathrm{p}$.

Rudnick, R.L. and Gao, S., 2003, The composition of the continental crust, in Rudnick, R.L., ed., Treatise on Geochemistry: Oxford, Elsevier-Pergamon, p. 1-64.

Shacklette, H.T., and Boerngen, J.G., 1984, Element concentrations in soils and other surficial materials of the conterminous United States: U.S. Geological Survey Professional Paper 1270, 105 p.

Sloto, R.A., 2009, The mines and minerals of Chester County, Pennsylvania: privately published, $469 \mathrm{p}$.

Sloto, R.A., and Dickinson, L.D., 1994, The French Creek Mine, St. Peters, Chester County, Pennsylvania: The Mineralogical Record, v. 25, p. 105-120.

Smith, R.C. II, Berkheiser, S.W., Jr., and Hoff, D.T., 1988, Locations and analyses of selected early Mesozoic copper occurrences in Pennsylvania, in Froelich, A.J., and Robinson, Jr., G.R., Studies of the early Mesozoic basins of the Eastern United States: U.S. Geological Survey Bulletin 1776, p. 320-330.

Spencer, A.C., 1908, Magnetite deposits of the Cornwall type in Pennsylvania: U.S. Geological Survey Bulletin 359, $102 \mathrm{p}$.

U.S. Environmental Protection Agency, 2007, Method 6200Field portable X-ray fluorescence spectrometry for the determination of elemental concentrations in soil and sediment, accessed October 28, 2010, at http://www.epa.gov/ osw/hazard/testmethods/sw846/pdfs/6200.pdf. 
U.S. Environmental Protection Agency, 2009, National primary drinking water regulations: U.S. Environmental Protection Agency report EPA 816-F-09-0004, 6 p.

U.S. Environmental Protection Agency, 2010a, X-Ray fluorescence (XRF) spectrometry, accessed October 28, 2010, at http://www.epa.gov/compliance/neic/field/xray.html.

U.S. Environmental Protection Agency, 2010b, National recommended water quality criteria, accessed June 9, 2010, at $h t t p: / / w w w . e p a . g o v / w a t e r s c i e n c e / c r i t e r i a / w q c t a b l e / i n d e x$. html.

U.S. Geological Survey, 1997 to present, National field manual for the collection of water-quality data: U.S. Geological Survey Techniques of Water-Resources Investigations, book 9 , chap. A4, variously paginated.

U.S. Geological Survey, 2009, Water-resources data for the United States, water year 2008: U.S. Geological Survey Water-Data Report WDR-US-2008, accessed June 1, 2010, at $h t t p: / / w d r$ water.usgs.gov/wy2008/search.jsp.

Walker, J.E., 1966, Hopewell village the dynamics of a nineteenth century iron making community: Philadelphia, PA, University of Pennsylvania Press, 526 p. 


\section{Tables 5 and 7}




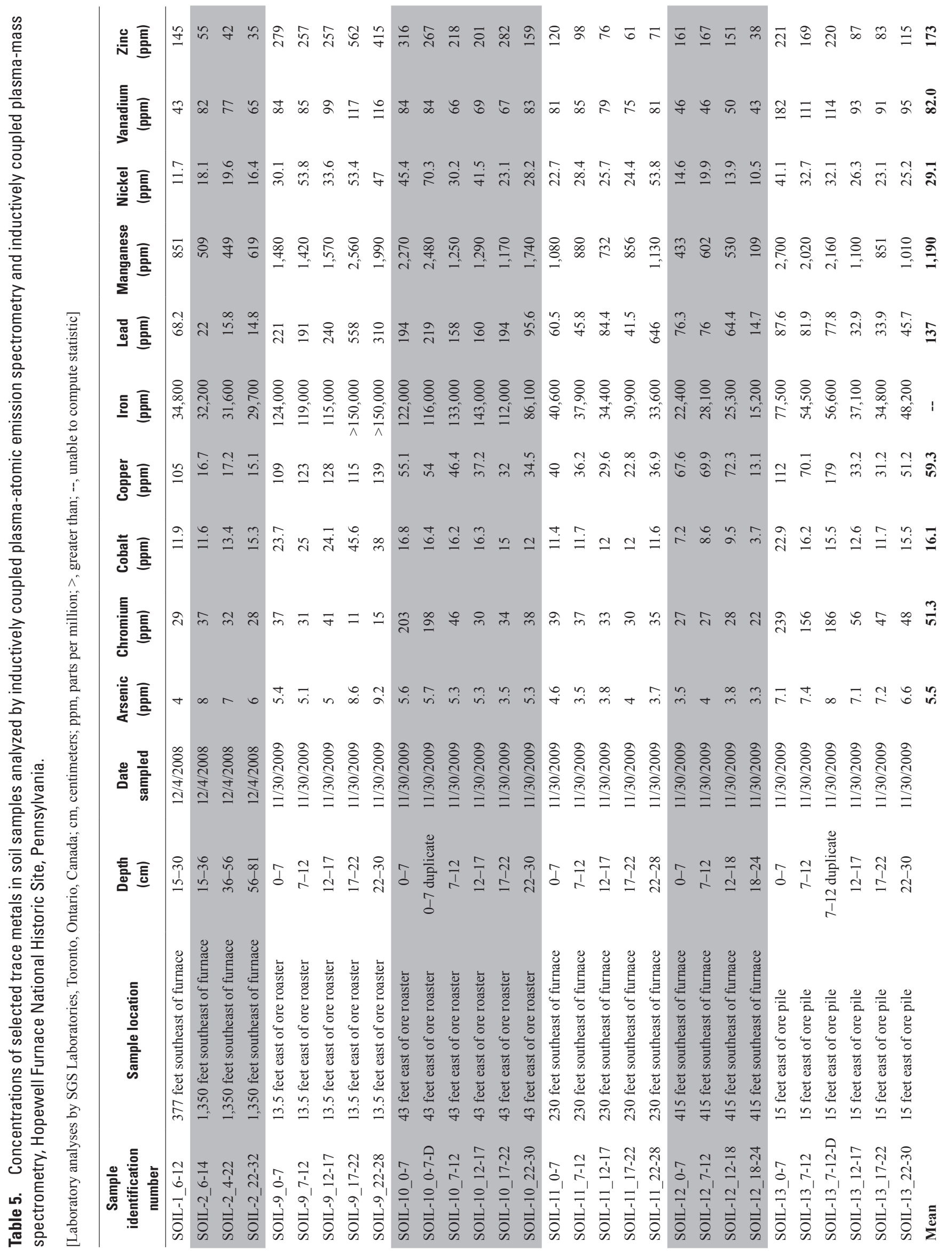




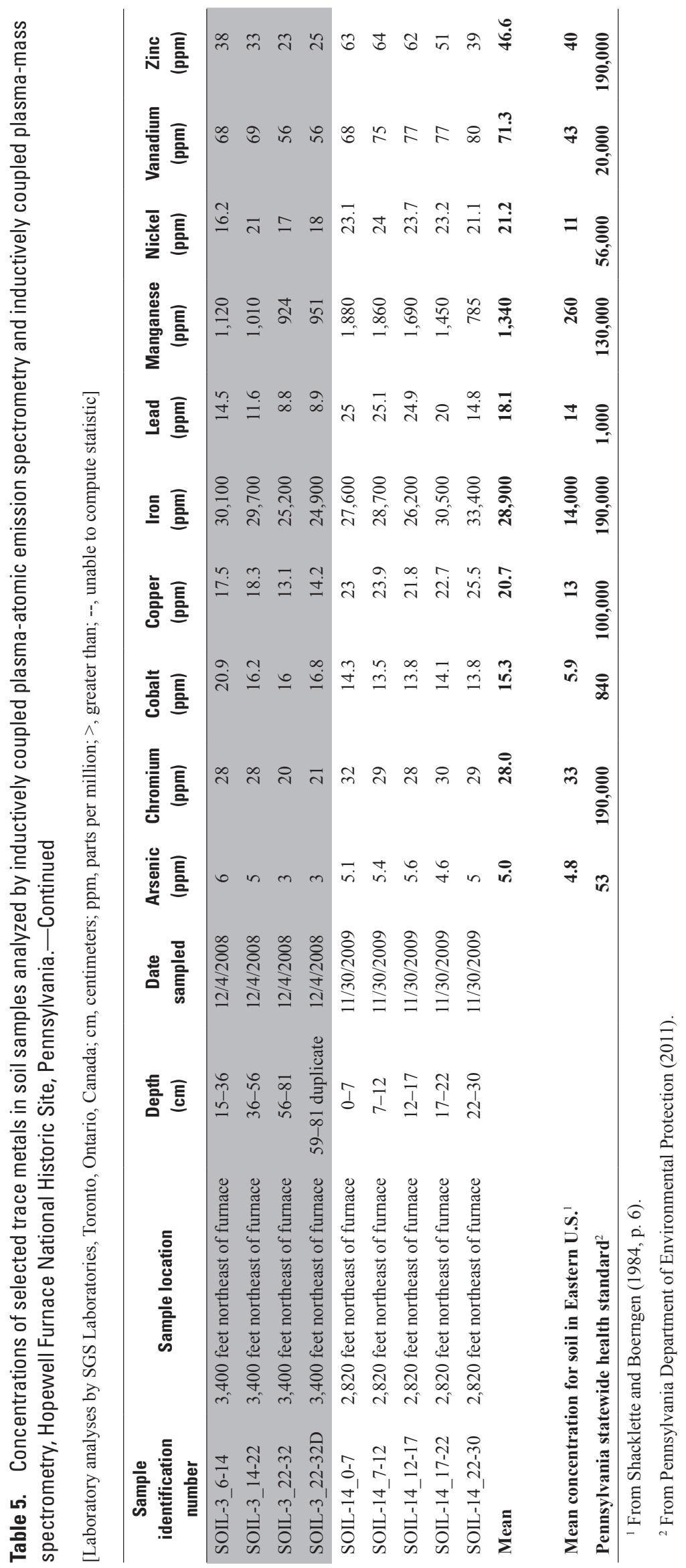




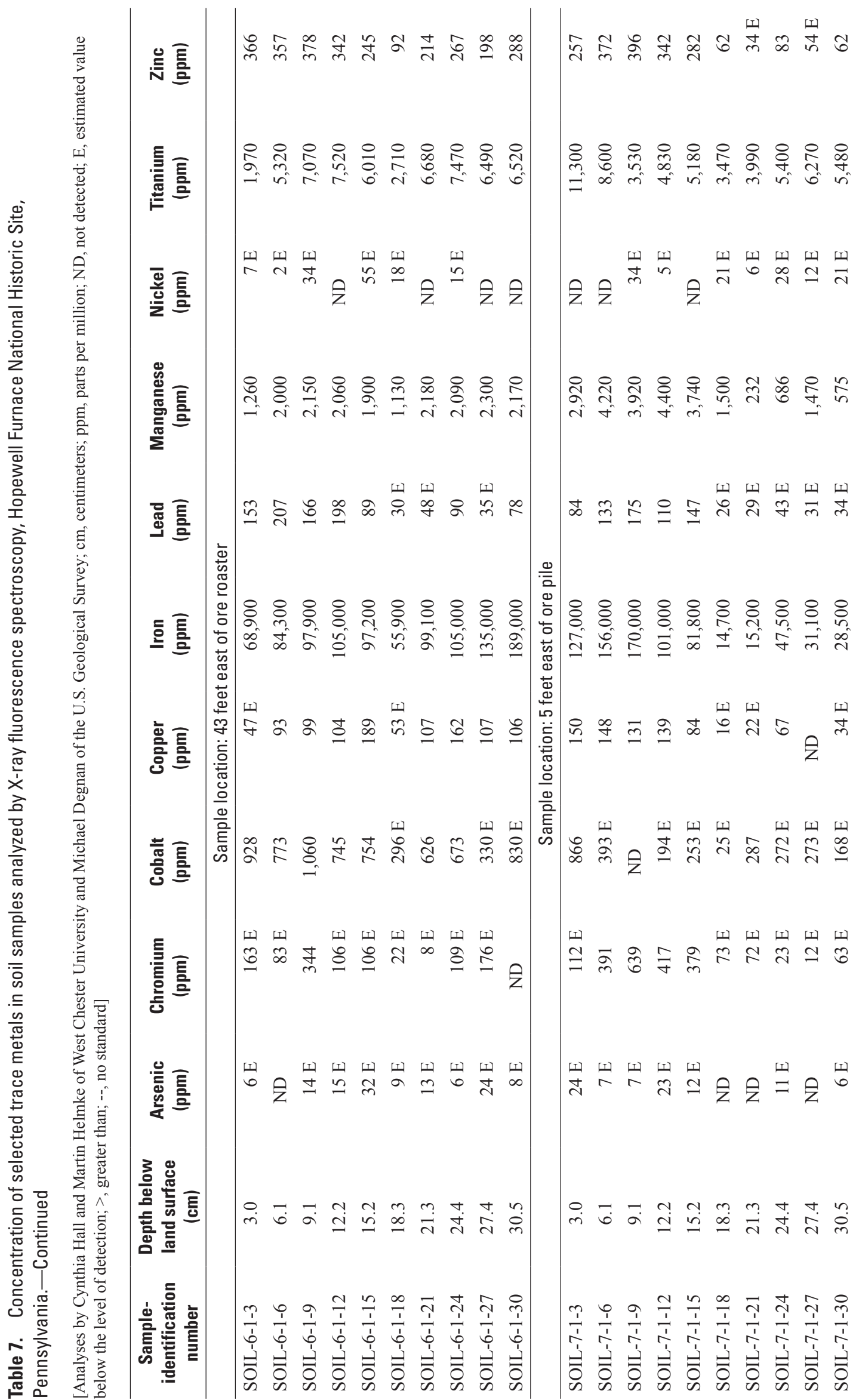




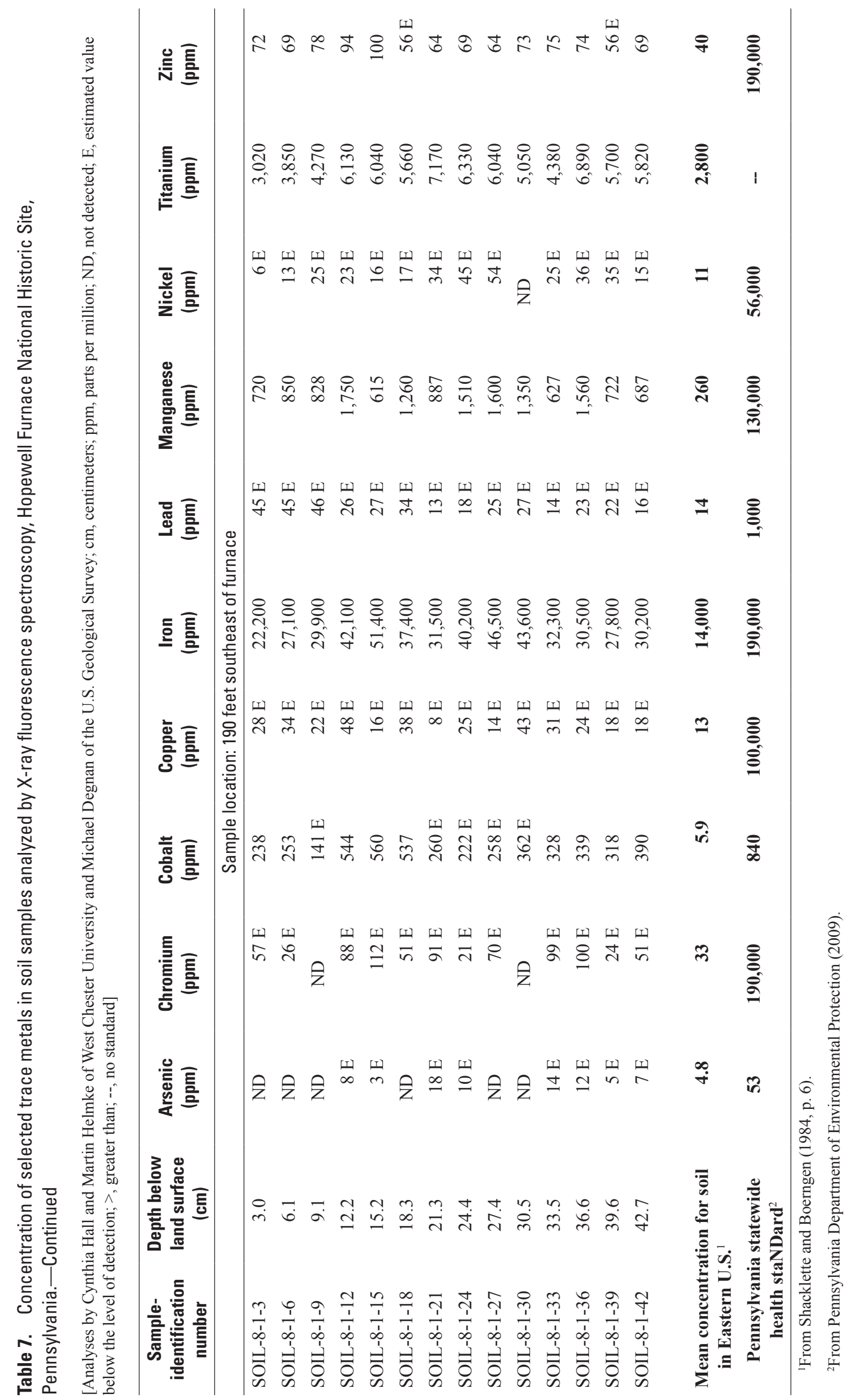




\section{Appendix 1. Tables A-K}

Table A. Results of laboratory analysis by inductively coupled plasma-atomic emission spectrometry and inductively coupled plasma-mass spectrometry of ore samples from the Hopewell and Jones mines, southeastern Pennsylvania

Table B. Results of laboratory analysis by wavelength dispersive X-ray fluorescence of ore samples from the Hopewell and Jones mines, southeastern Pennsylvania

Table C. Results of laboratory analysis by inductively coupled plasma-atomic emission spectrometry and inductively coupled plasma-mass spectrometry of slag samples from Hopewell Furnace National Historic Site, Pennsylvania.

Table D. Results of laboratory analysis by wavelength dispersive X-ray fluorescence of slag samples from Hopewell Furnace National Historic Site, Pennsylvania 48

Table E. Results of laboratory analysis by inductively coupled plasma-atomic emission spectrometry and inductively coupled plasma-mass spectrometry of soil samples from Hopewell Furnace National Historic Site, Pennsylvania

Table F. Results of laboratory analysis by wavelength dispersive X-ray fluorescence of soil samples from Hopewell Furnace National Historic Site, Pennsylvania

Table G. Results of analyses by X-ray fluorescence spectroscopy of soil samples from Hopewell Furnace National Historic Site, Pennsylvania .....

Table H. Results of analysis by X-ray fluorescence spectroscopy of cast iron artifacts in the Hopewell Furnace National Historic Site museum, Pennsylvania.

Table I. Results of field and laboratory analysis for groundwater samples, Hopewell Furnace National Historic Site, Pennsylvania.

Table J. Results of laboratory analysis for surface-water base-flow samples,

Table K. Benthic macroinvertebrates identified from 300 organism subsamples collected from sites at Hopewell Furnace National Historical Site, November 2008 


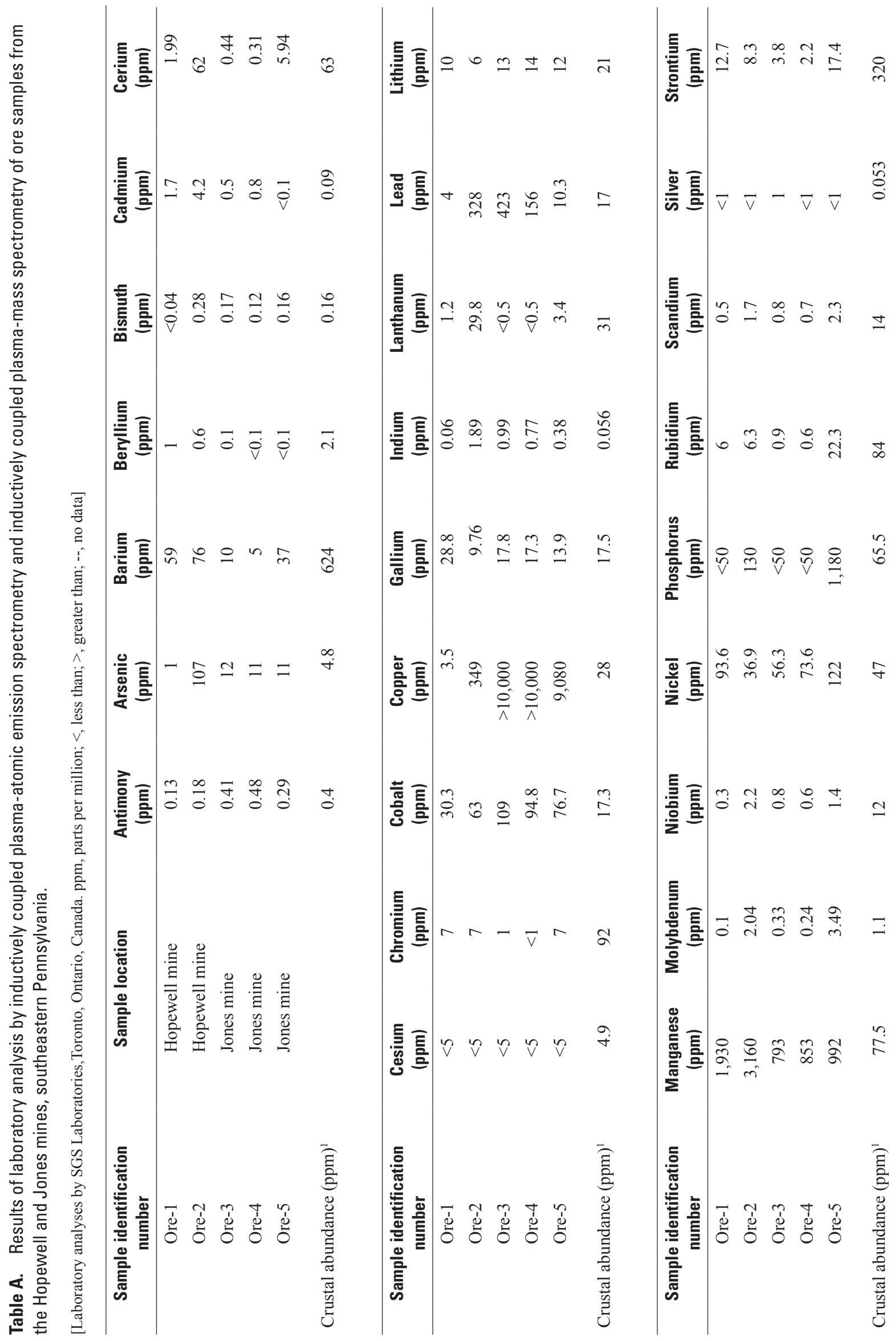




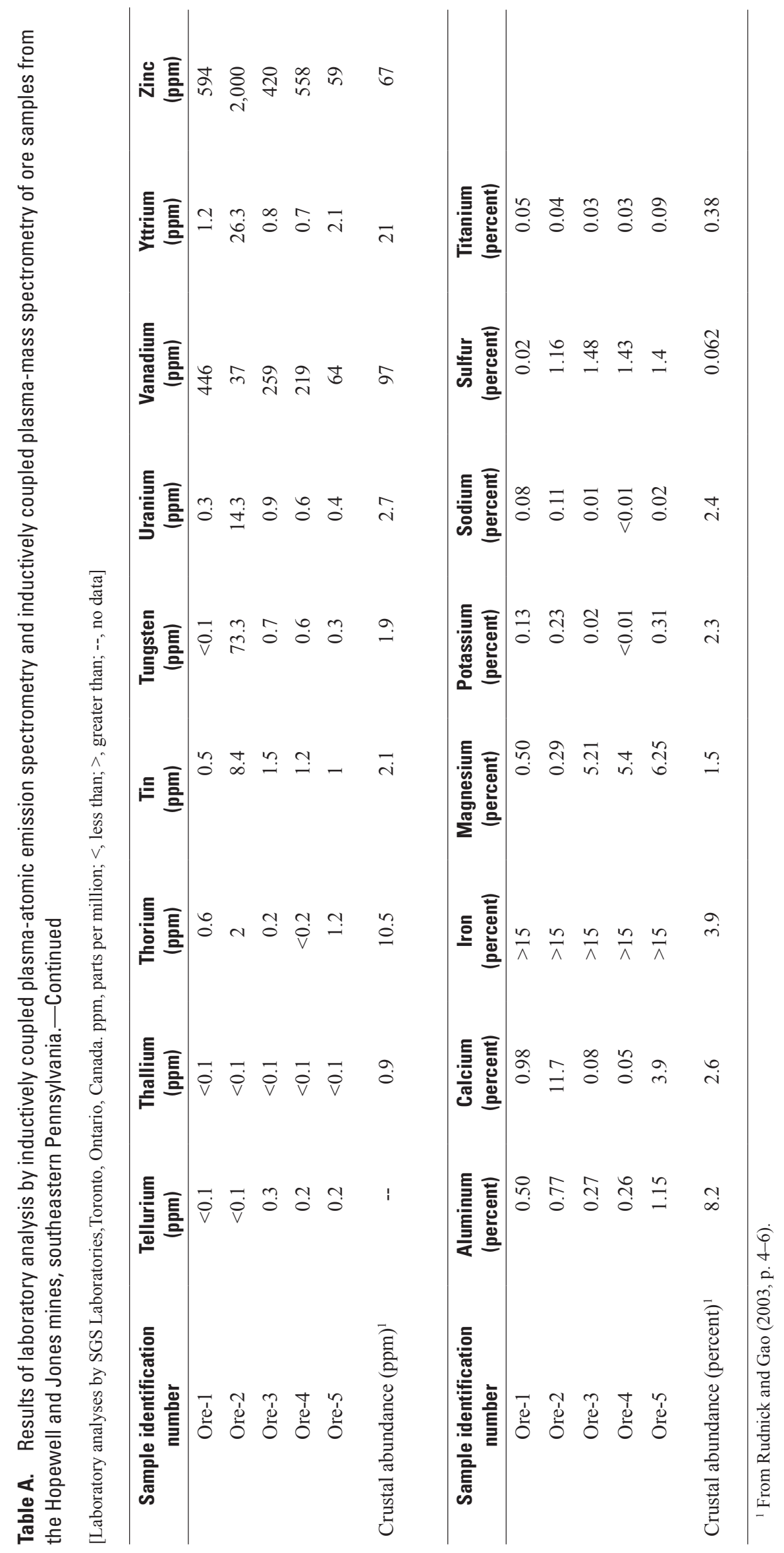




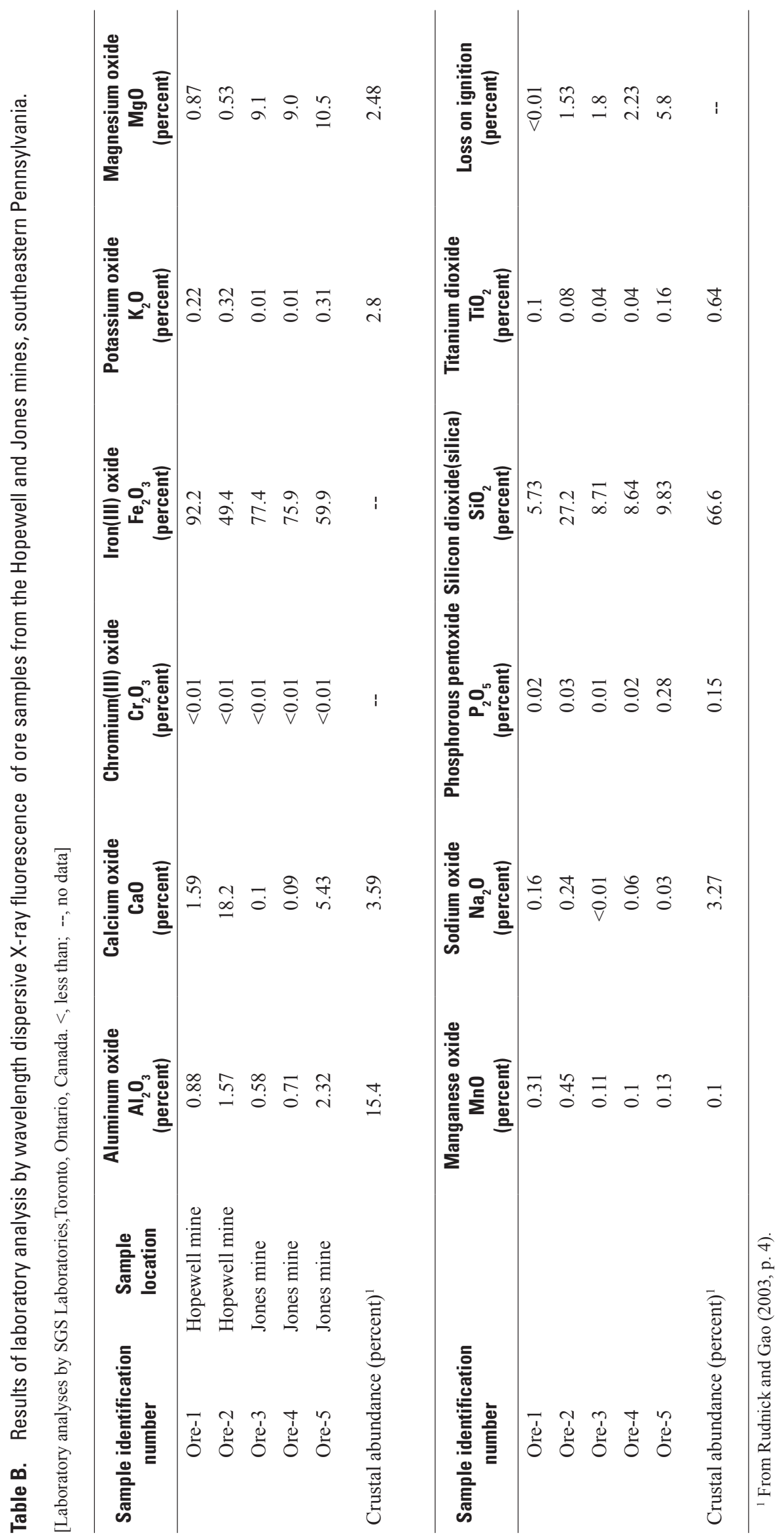




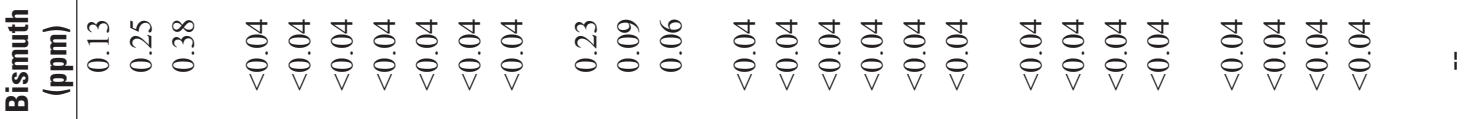

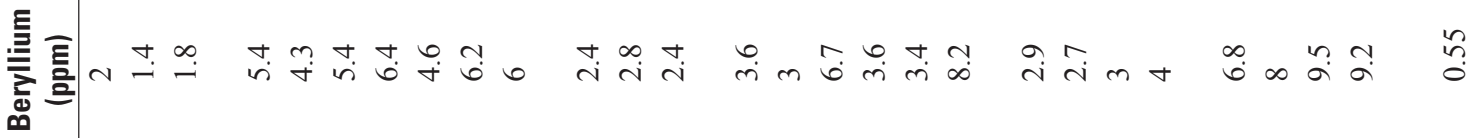

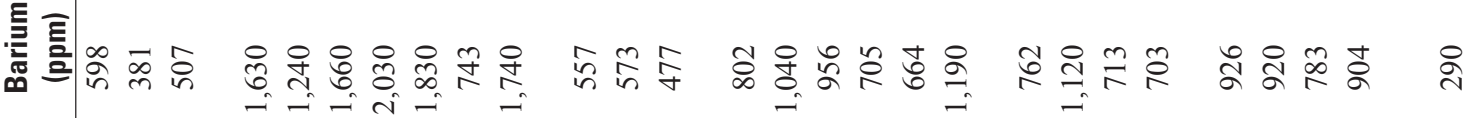

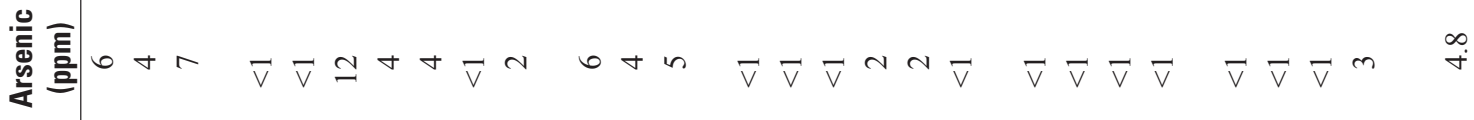

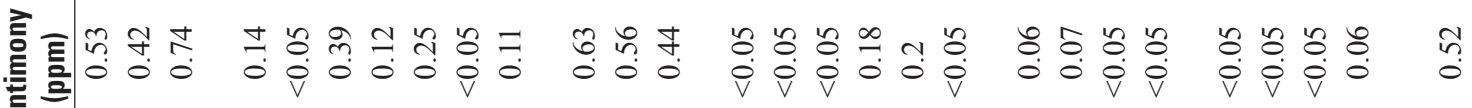

$\stackrel{8}{8.8}$

青目目

iv $N$

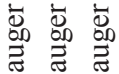

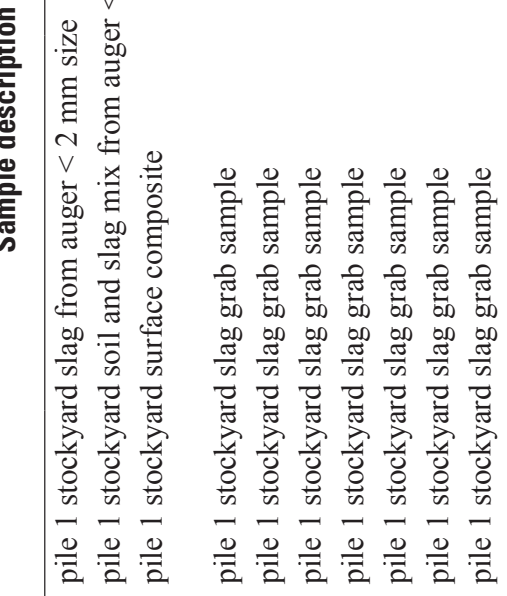

离总

in

0000

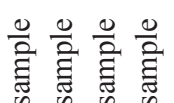

을

$\div$

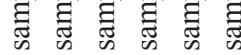

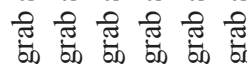

訊

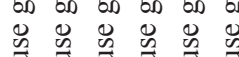

윰 윰 윰

号号号

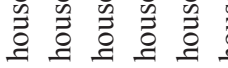

$\begin{array}{llll}0 & 0 & 0 \\ 0 & 0 & 0 \\ 0 & 0 & 0 & 0 \\ 0 & 0 & 0 & 0\end{array}$

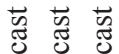

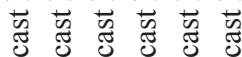

फ

फ

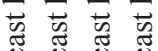

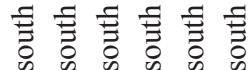

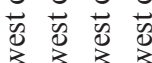

চ

तथ

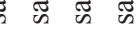

要

$\because \frac{0}{\square}$

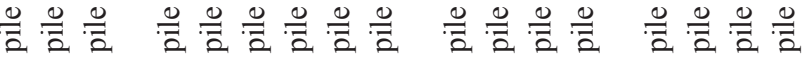

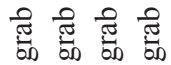

\&

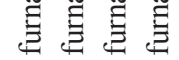

.

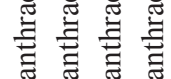

岁范范范

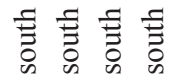

(am 


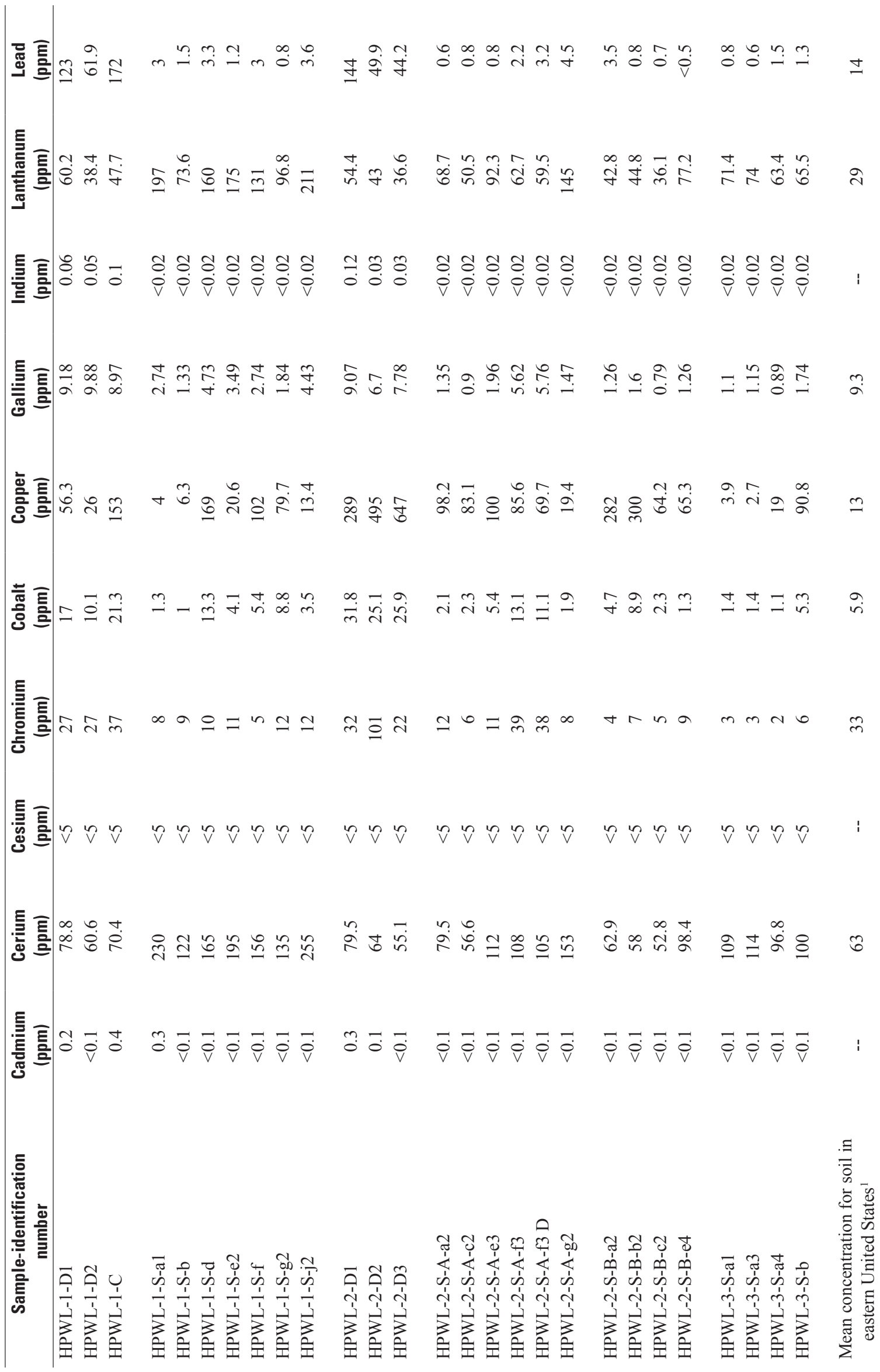




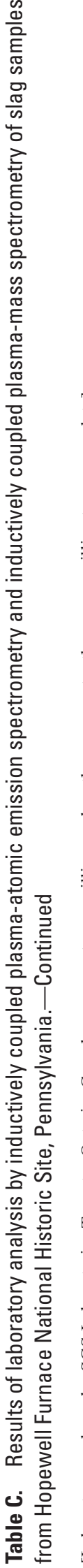

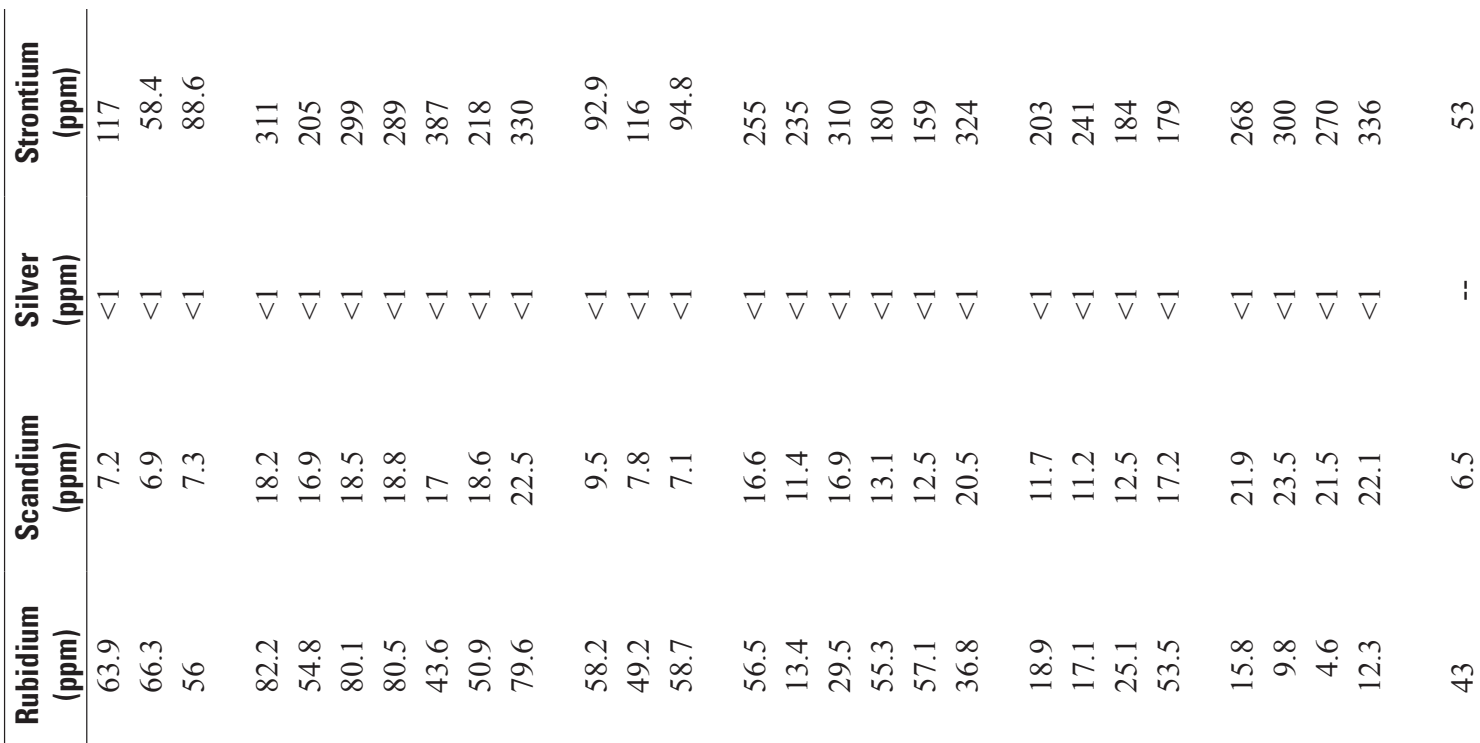

흘 $\overline{\bar{z}}$

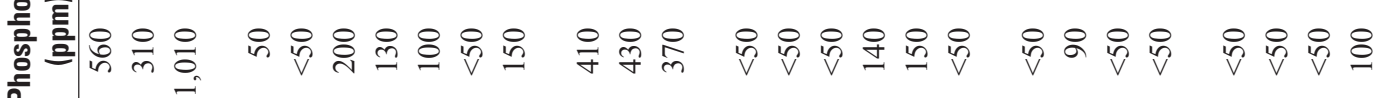

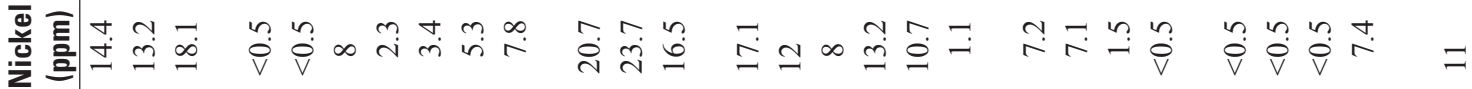

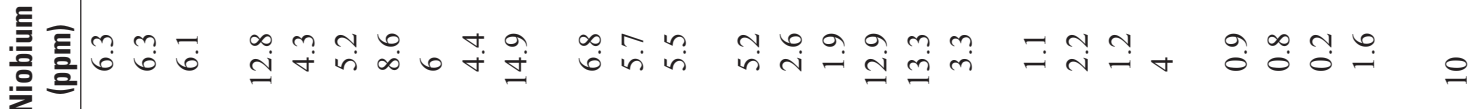

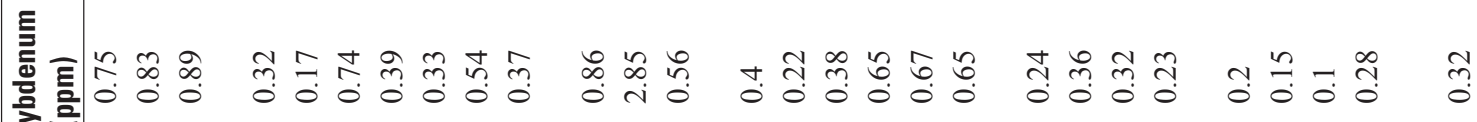

흘

。

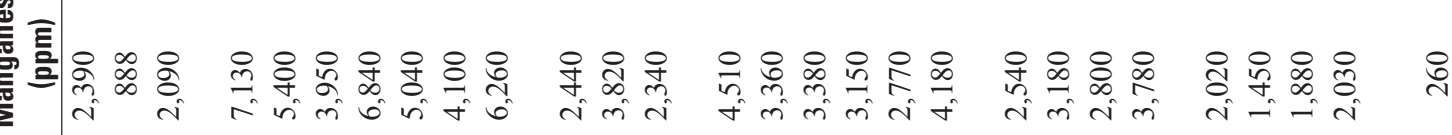

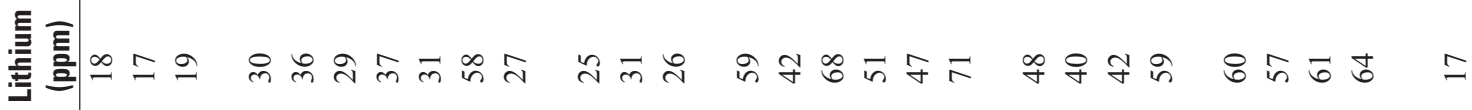

Iิ

ลิกิติติ

ชิำ

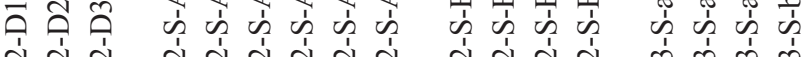

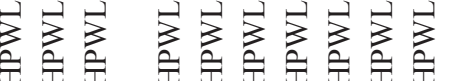

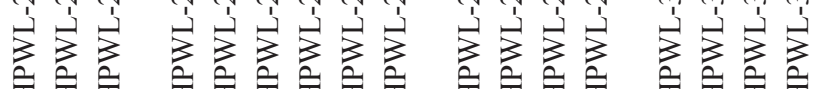




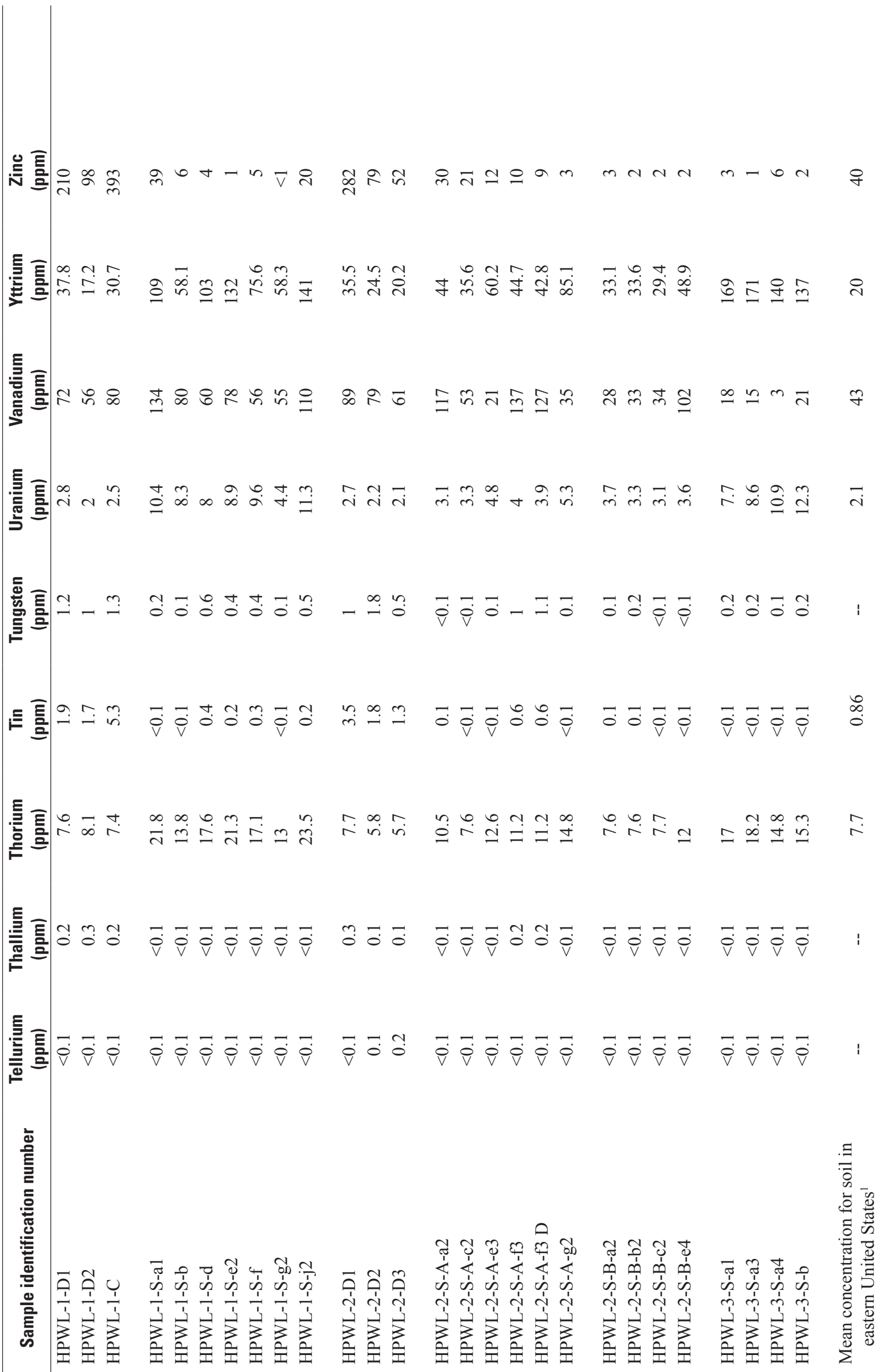




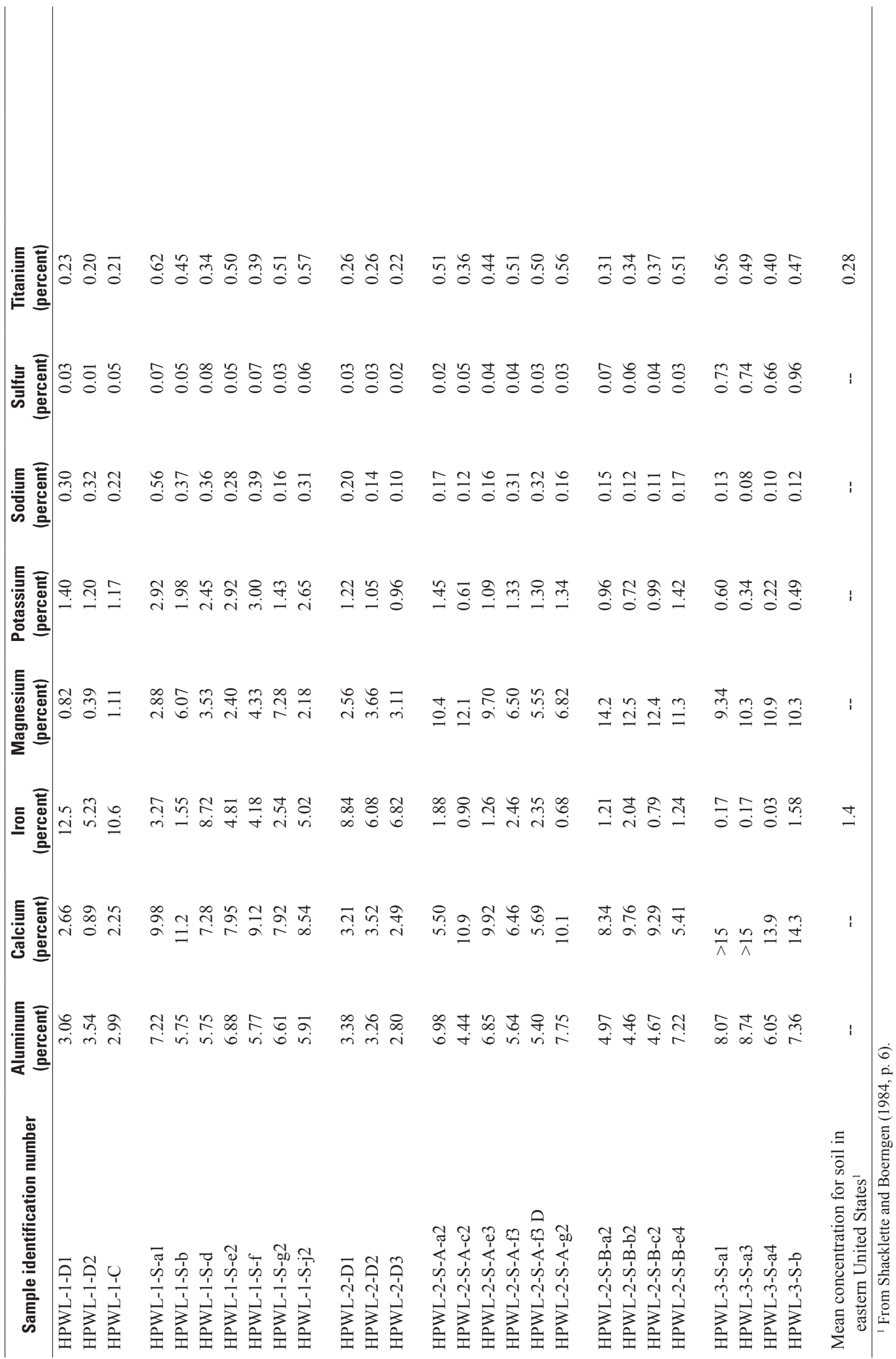



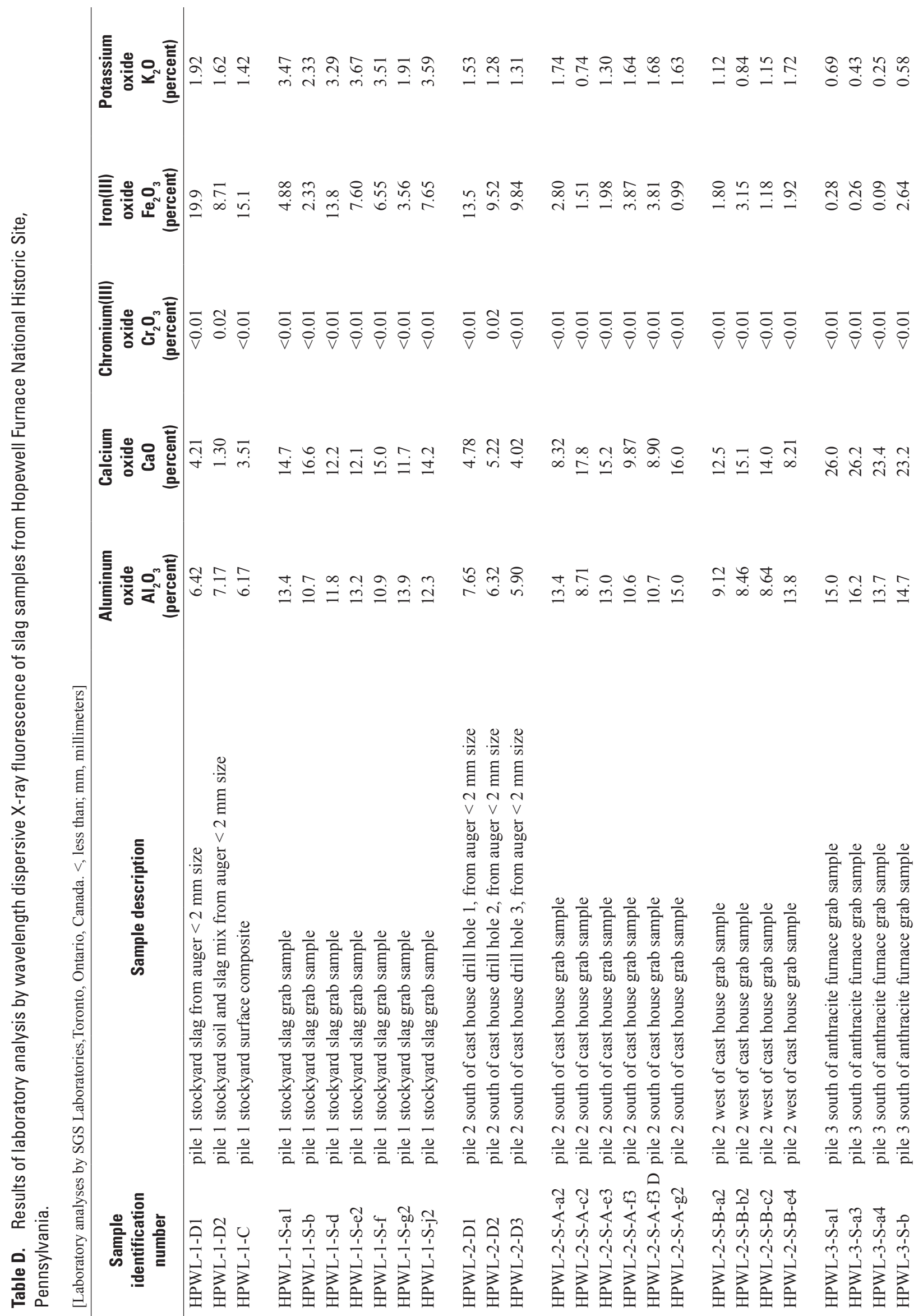


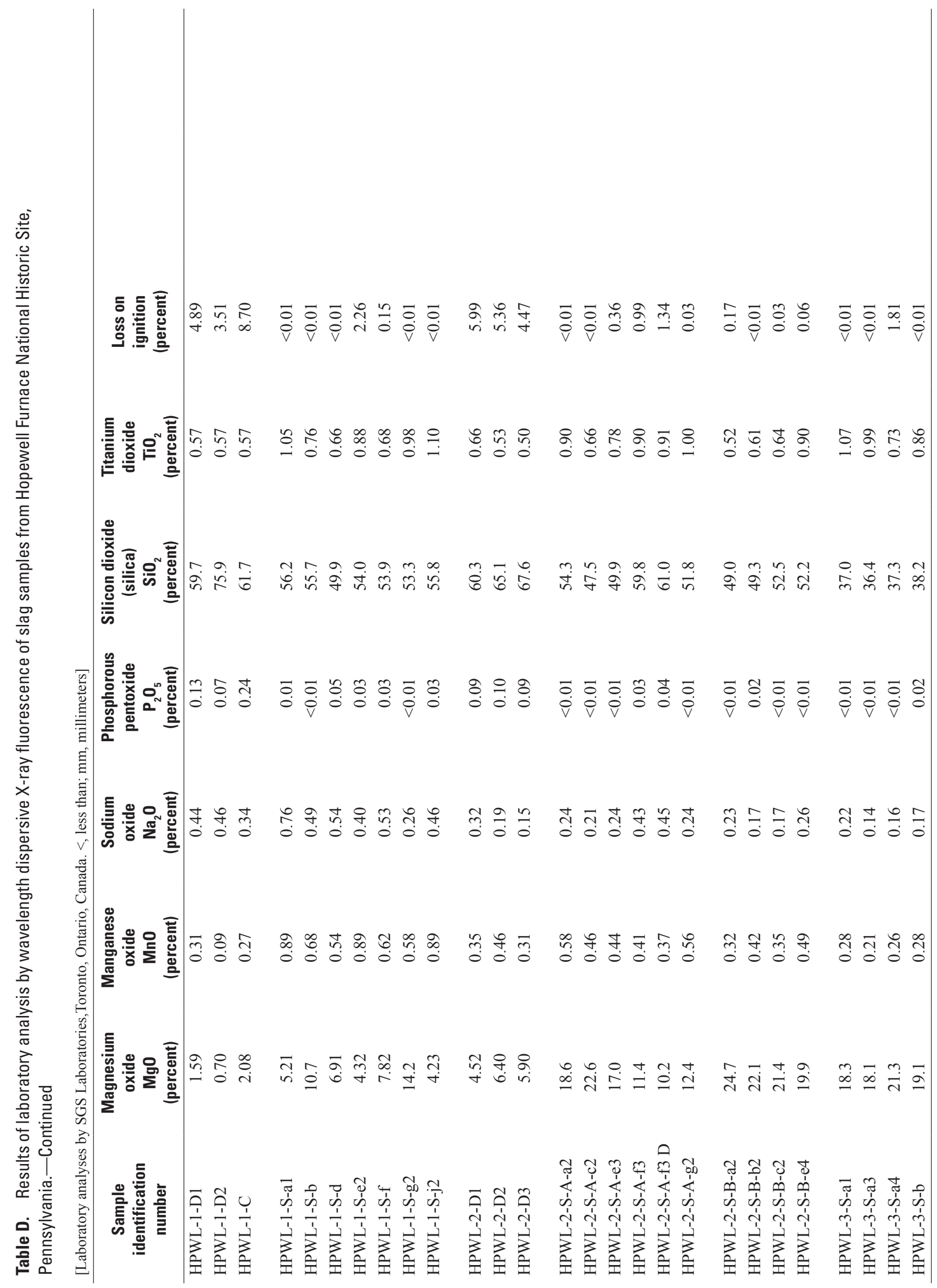




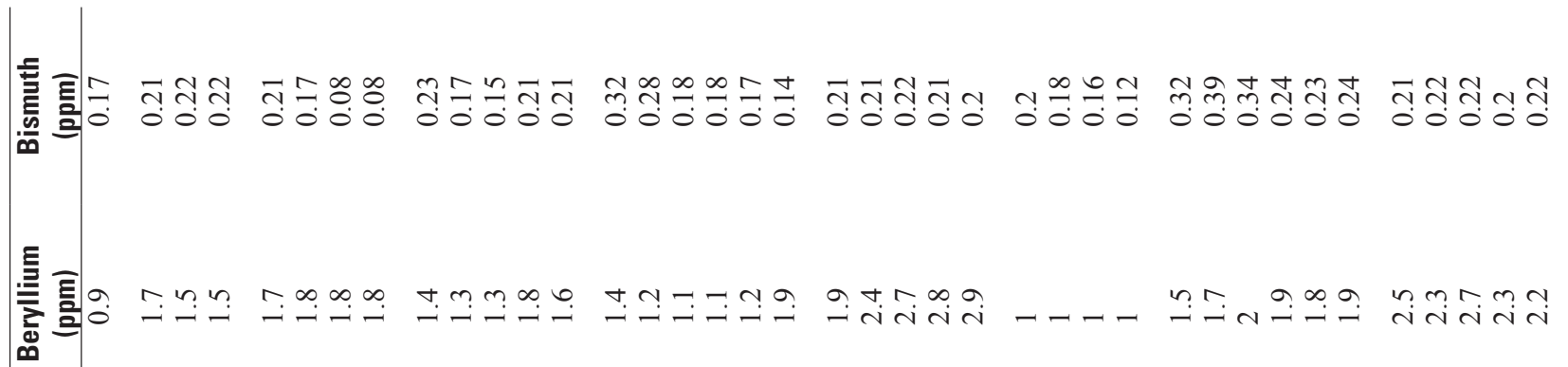

至 $\overline{\mathrm{E}}$

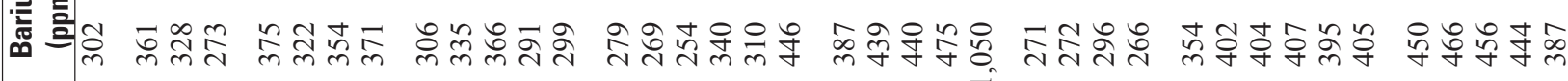

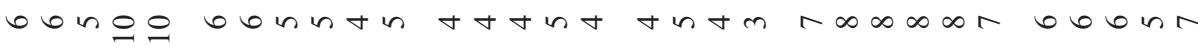

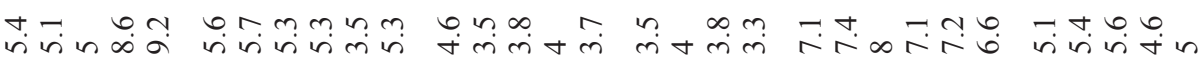

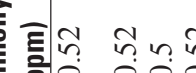

$\operatorname{n+ก} \stackrel{0}{\circ}$

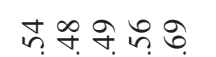

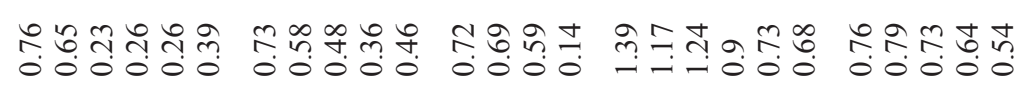

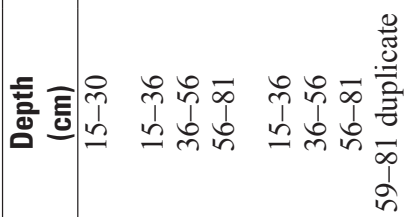

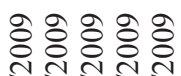

S.

ठे ठे

促

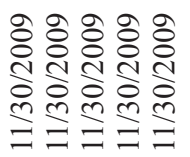

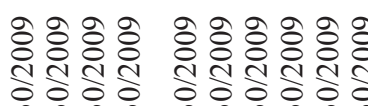

nan

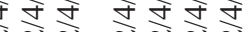

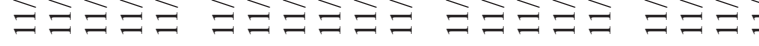

$\exists \Xi \exists \Xi \exists \Xi \exists \Xi \Xi$

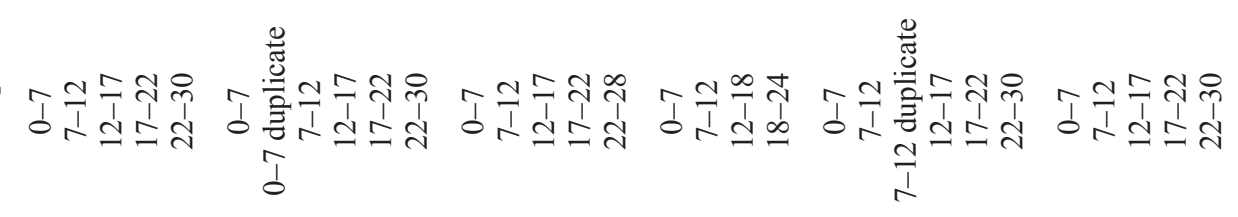

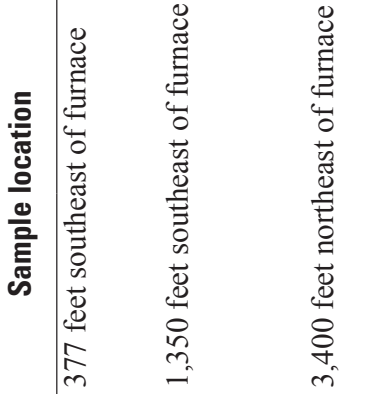

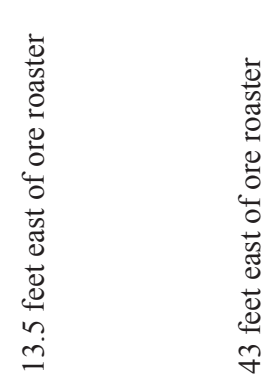

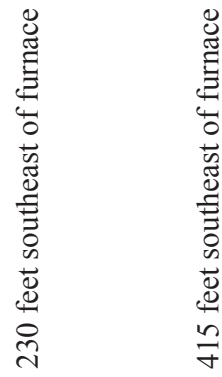

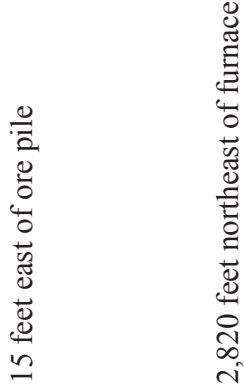




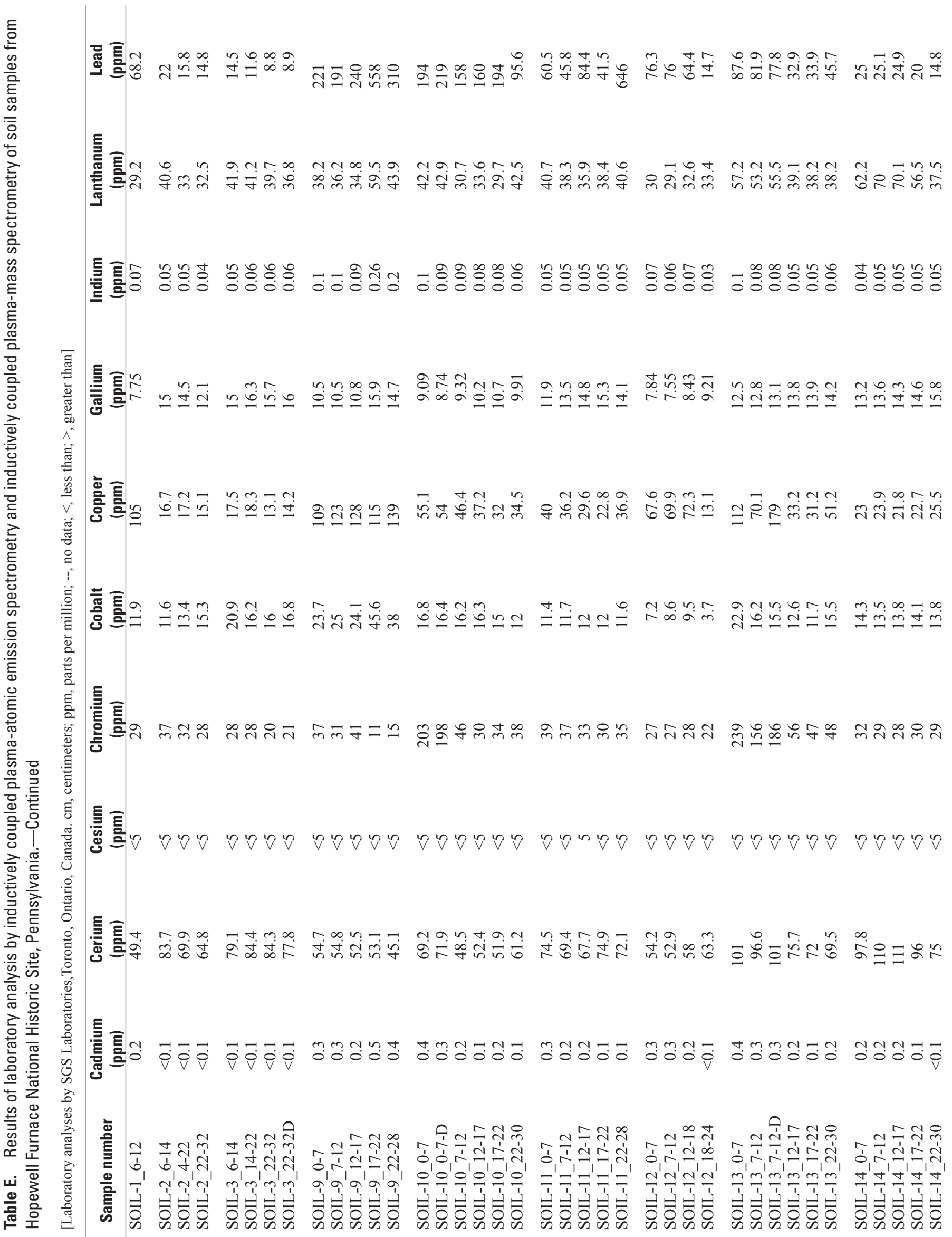




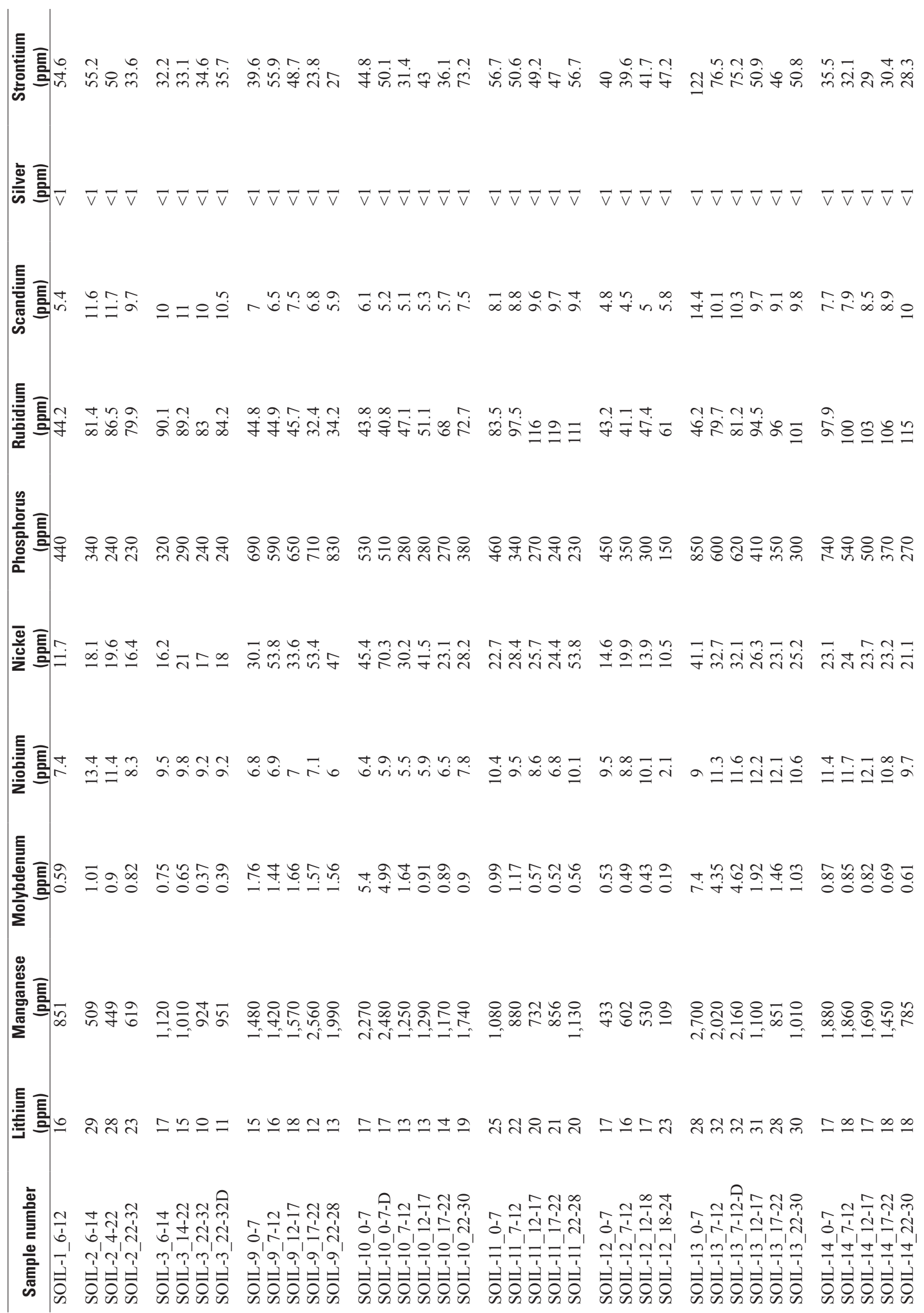


言

츨

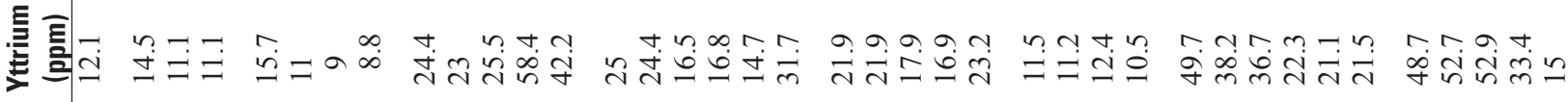

กำ

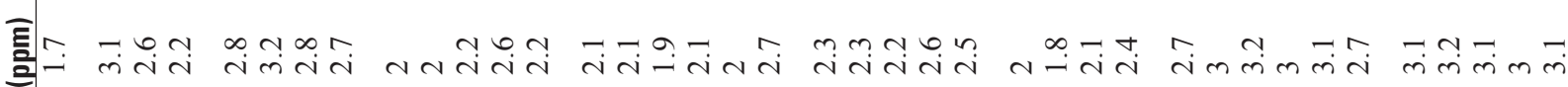

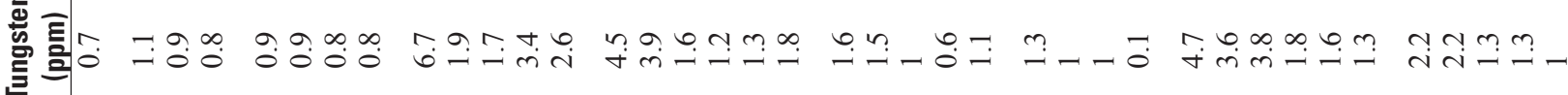

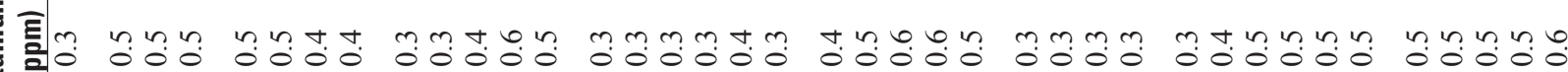
.

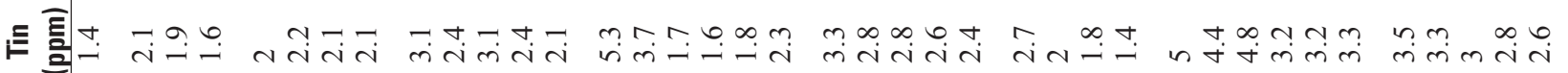

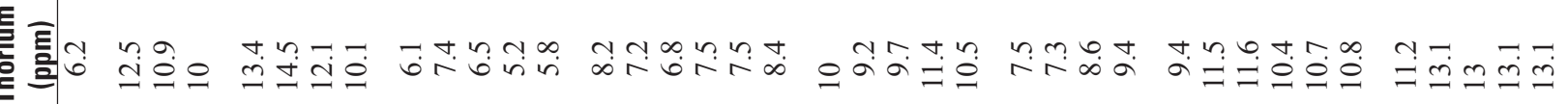

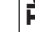

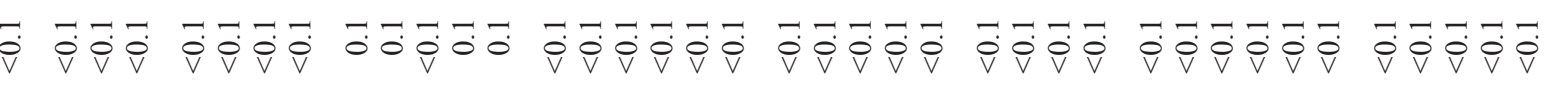

nะสำ

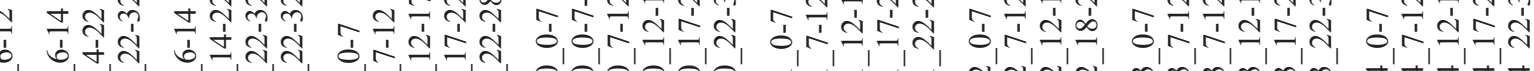

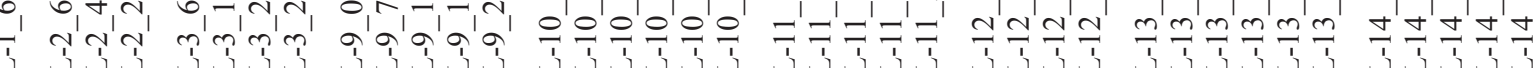

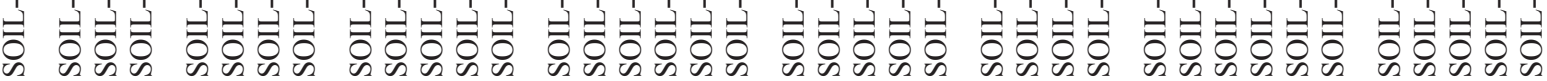




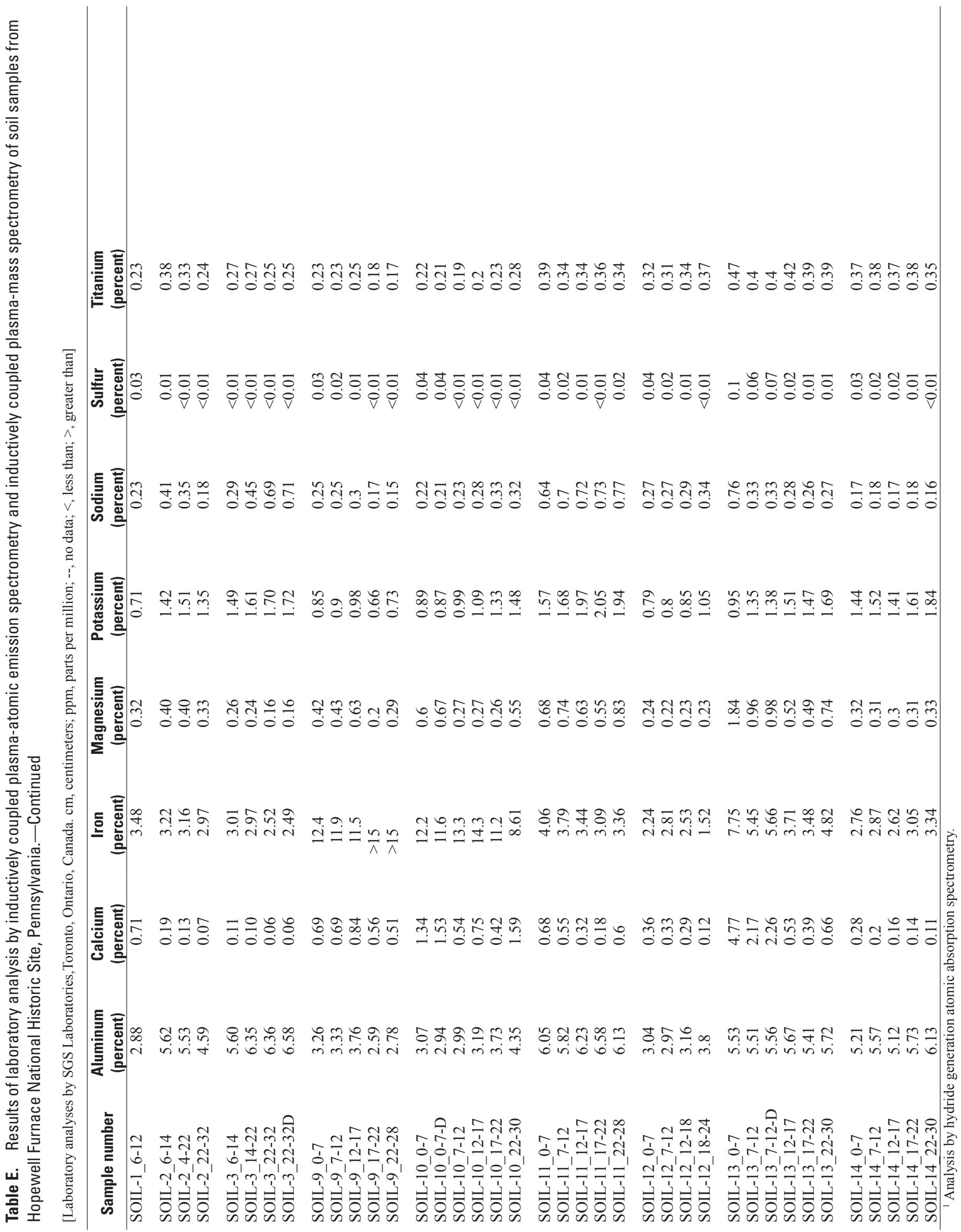




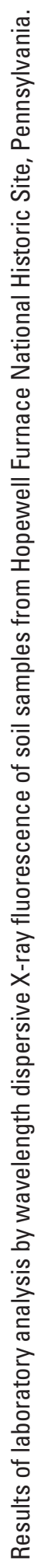

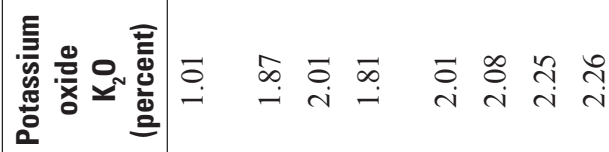

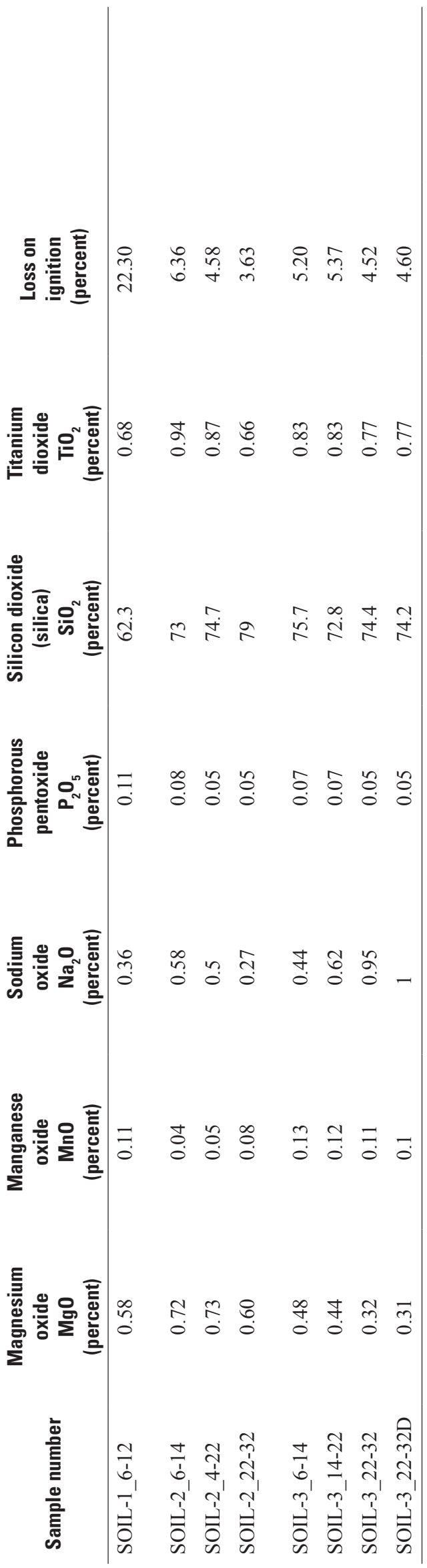


Table G. Results of analyses by X-ray fluorescence spectroscopy of soil samples from Hopewell Furnace National Historic Site, Pennsylvania.

[Analyses by Cynthia Hall and Martin Helmke of West Chester University and Michael Degnan of the U.S. Geological Survey. cm, centimeters; ppm, parts per million; E, estimated value below the level of detection; ND, not detected; >, greater than]

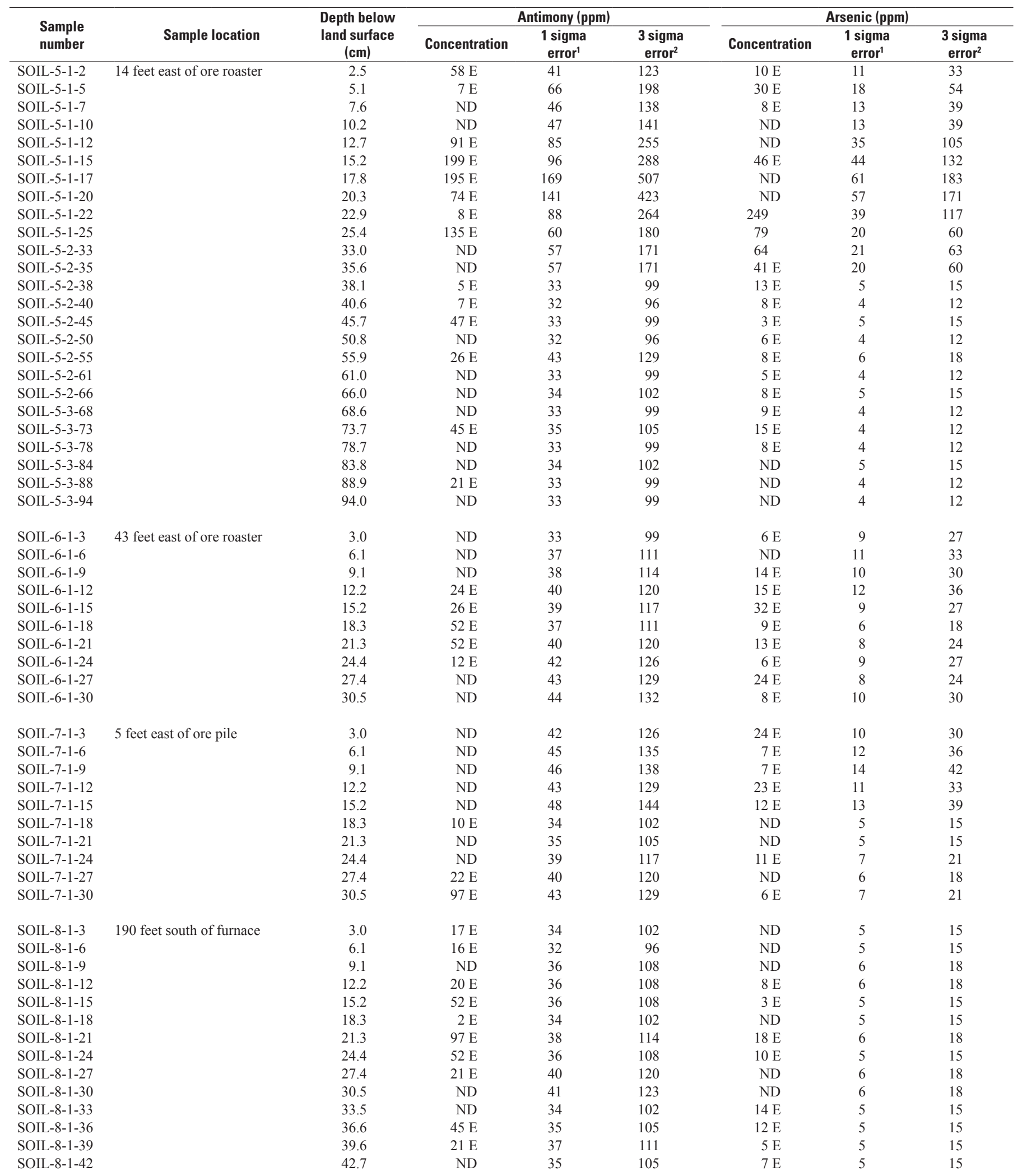


Table G. Results of analyses by X-ray fluorescence spectroscopy of soil samples from Hopewell Furnace National Historic Site, Pennsylvania.-Continued

[Analyses by Cynthia Hall and Martin Helmke of West Chester University and Michael Degnan of the U.S. Geological Survey. cm, centimeters; ppm, parts per million; E, estimated value below the level of detection; ND, not detected; >, greater than]

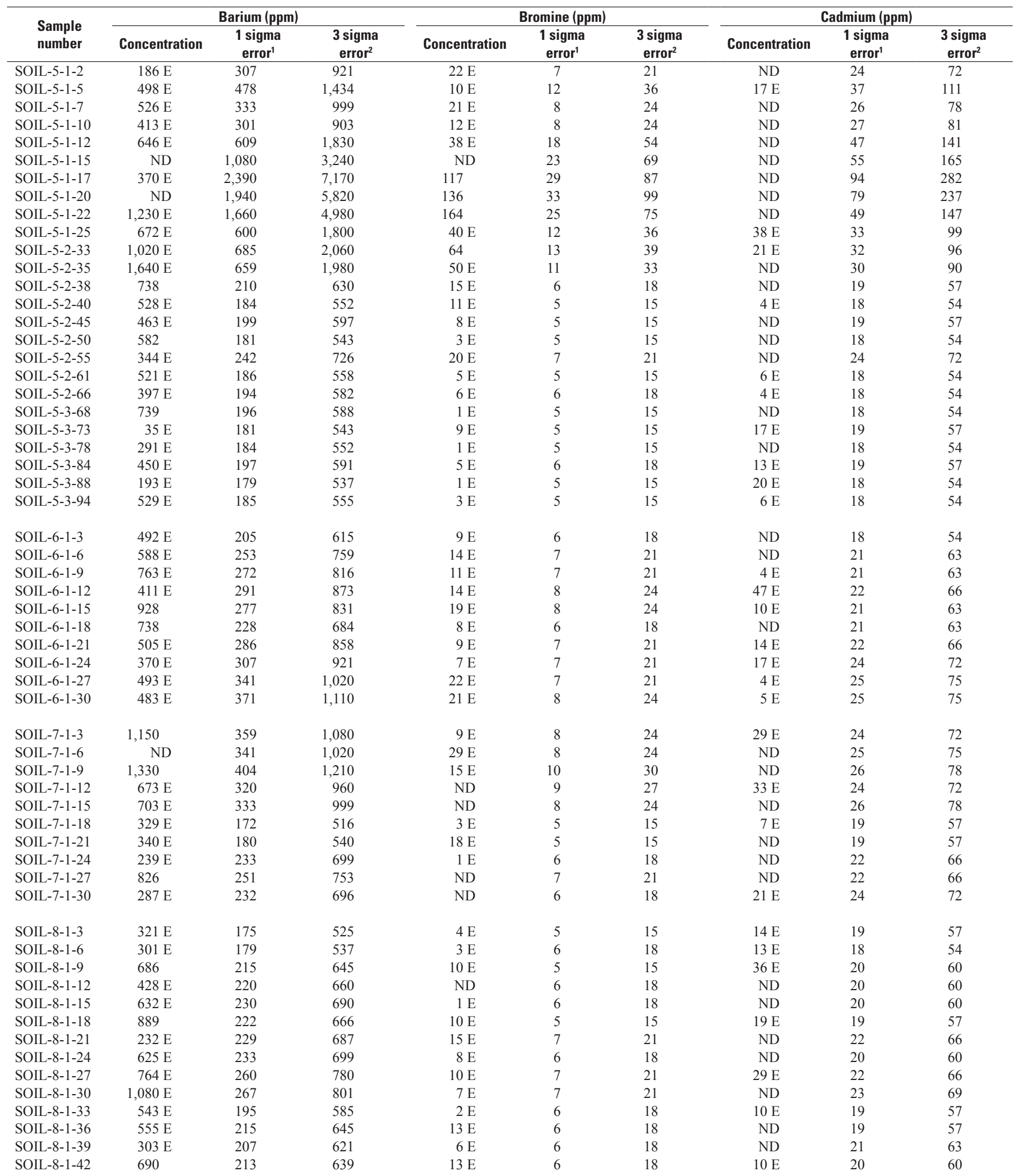


Table G. Results of analyses by X-ray fluorescence spectroscopy of soil samples from Hopewell Furnace National Historic Site, Pennsylvania.-Continued

[Analyses by Cynthia Hall and Martin Helmke of West Chester University and Michael Degnan of the U.S. Geological Survey. cm, centimeters; ppm, parts per million; E, estimated value below the level of detection; ND, not detected; >, greater than]

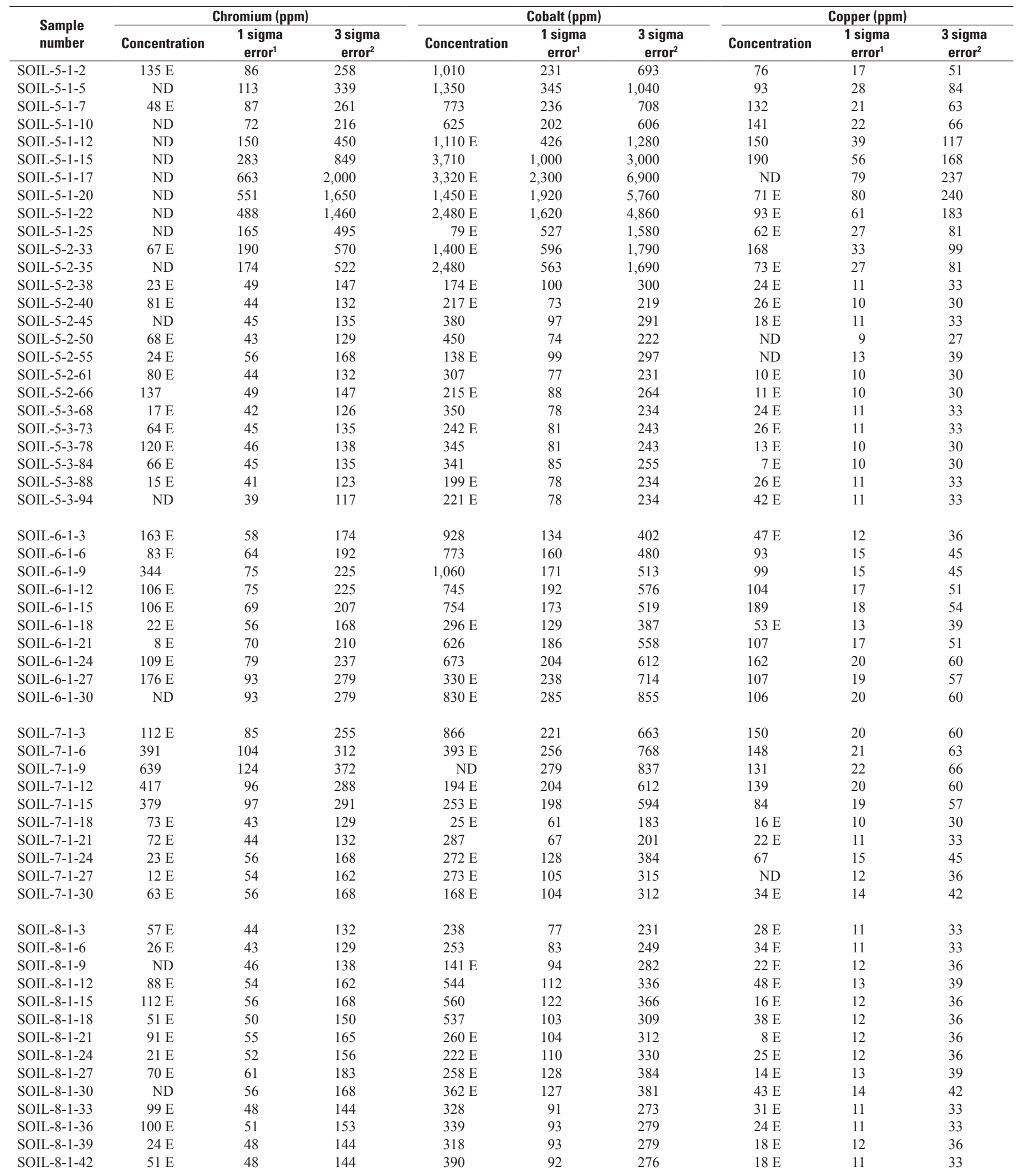


Table G. Results of analyses by X-ray fluorescence spectroscopy of soil samples from Hopewell Furnace National Historic Site, Pennsylvania.-Continued

[Analyses by Cynthia Hall and Martin Helmke of West Chester University and Michael Degnan of the U.S. Geological Survey. cm, centimeters; ppm, parts per million; E, estimated value below the level of detection; ND, not detected; >, greater than]

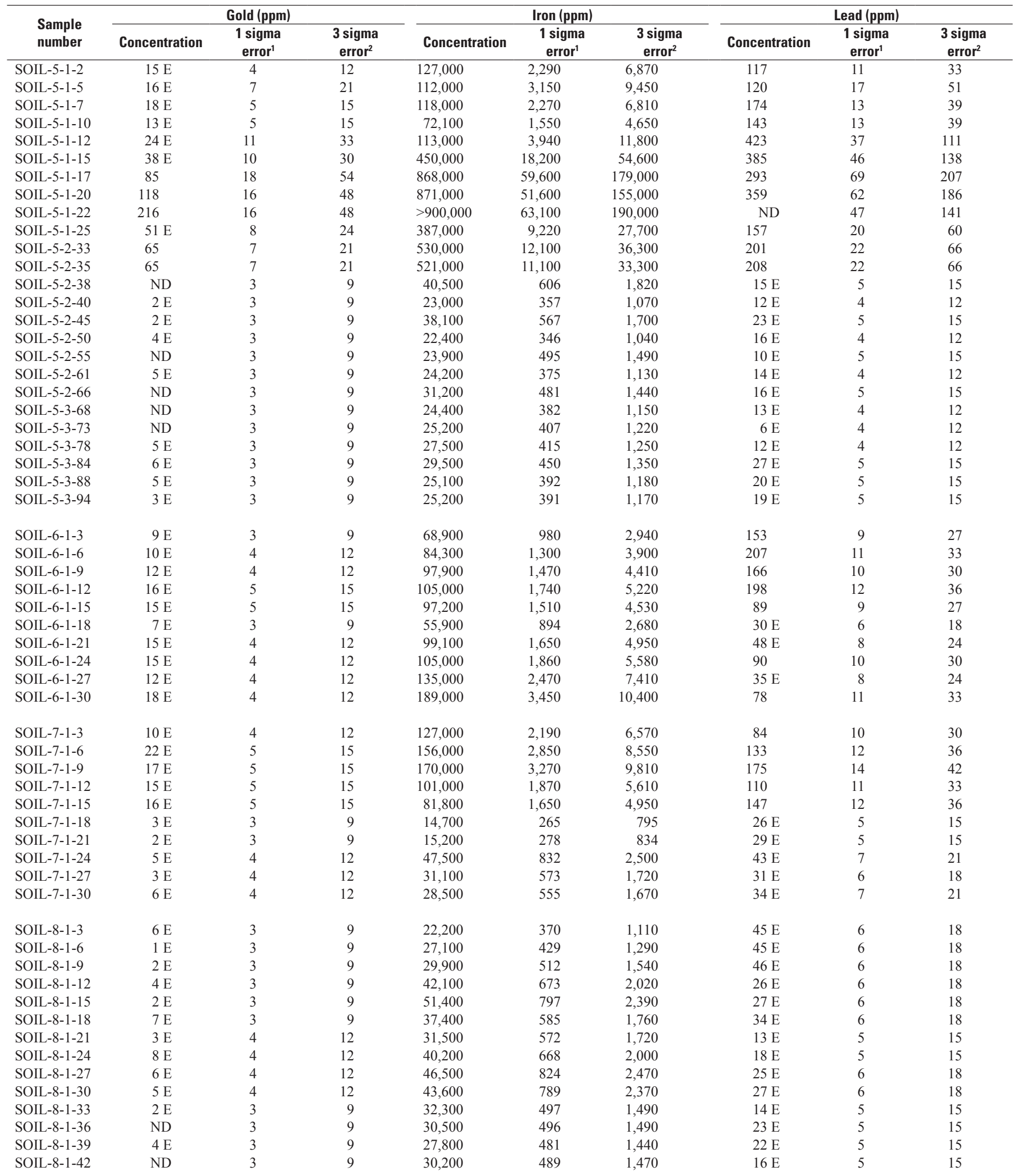


Table G. Results of analyses by X-ray fluorescence spectroscopy of soil samples from Hopewell Furnace National Historic Site, Pennsylvania.-Continued

[Analyses by Cynthia Hall and Martin Helmke of West Chester University and Michael Degnan of the U.S. Geological Survey. cm, centimeters; ppm, parts per million; E, estimated value below the level of detection; ND, not detected; >, greater than]

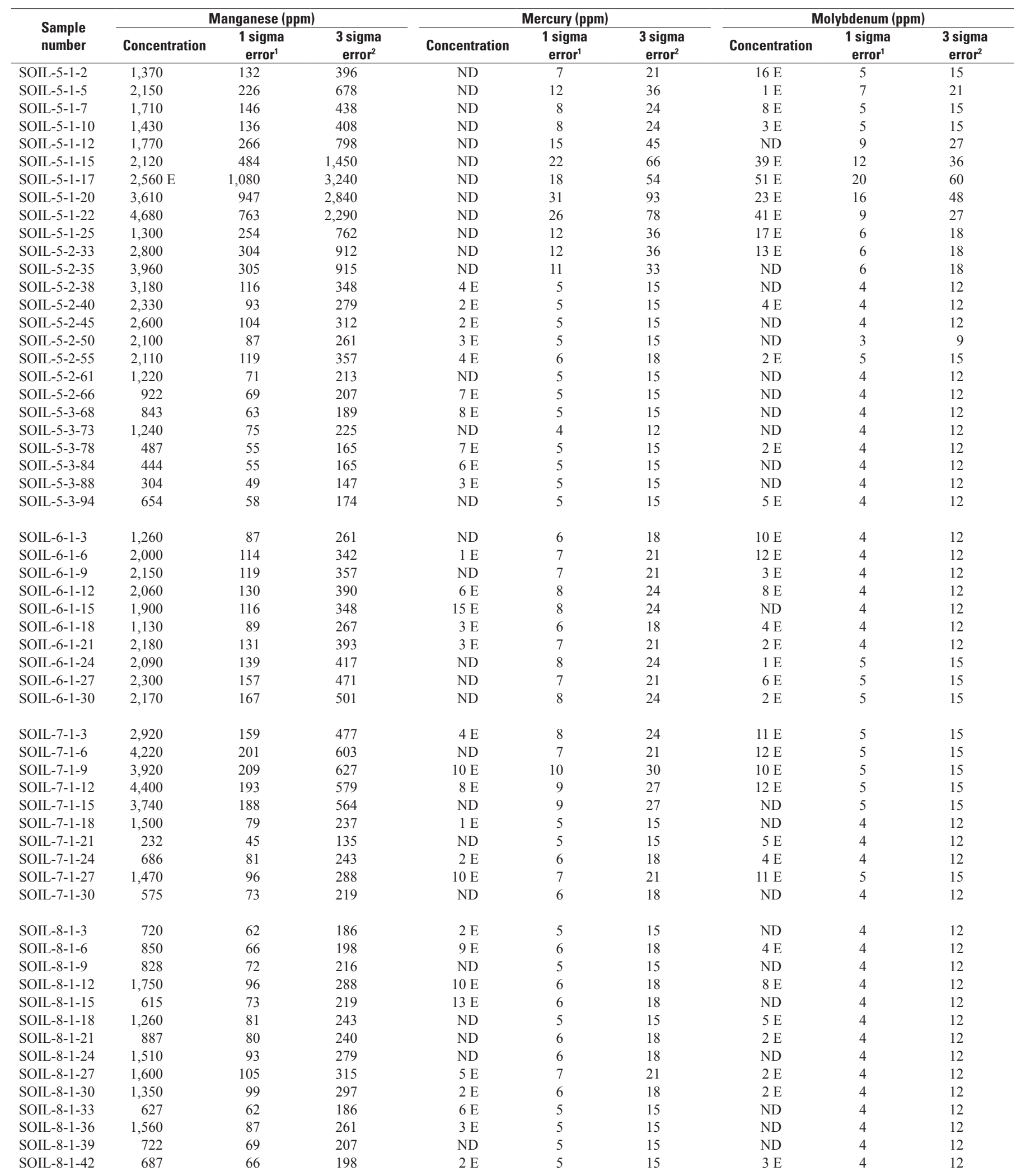


Table G. Results of analyses by X-ray fluorescence spectroscopy of soil samples from Hopewell Furnace National Historic Site, Pennsylvania.-Continued

[Analyses by Cynthia Hall and Martin Helmke of West Chester University and Michael Degnan of the U.S. Geological Survey. cm, centimeters; ppm, parts per million; E, estimated value below the level of detection; ND, not detected; >, greater than]

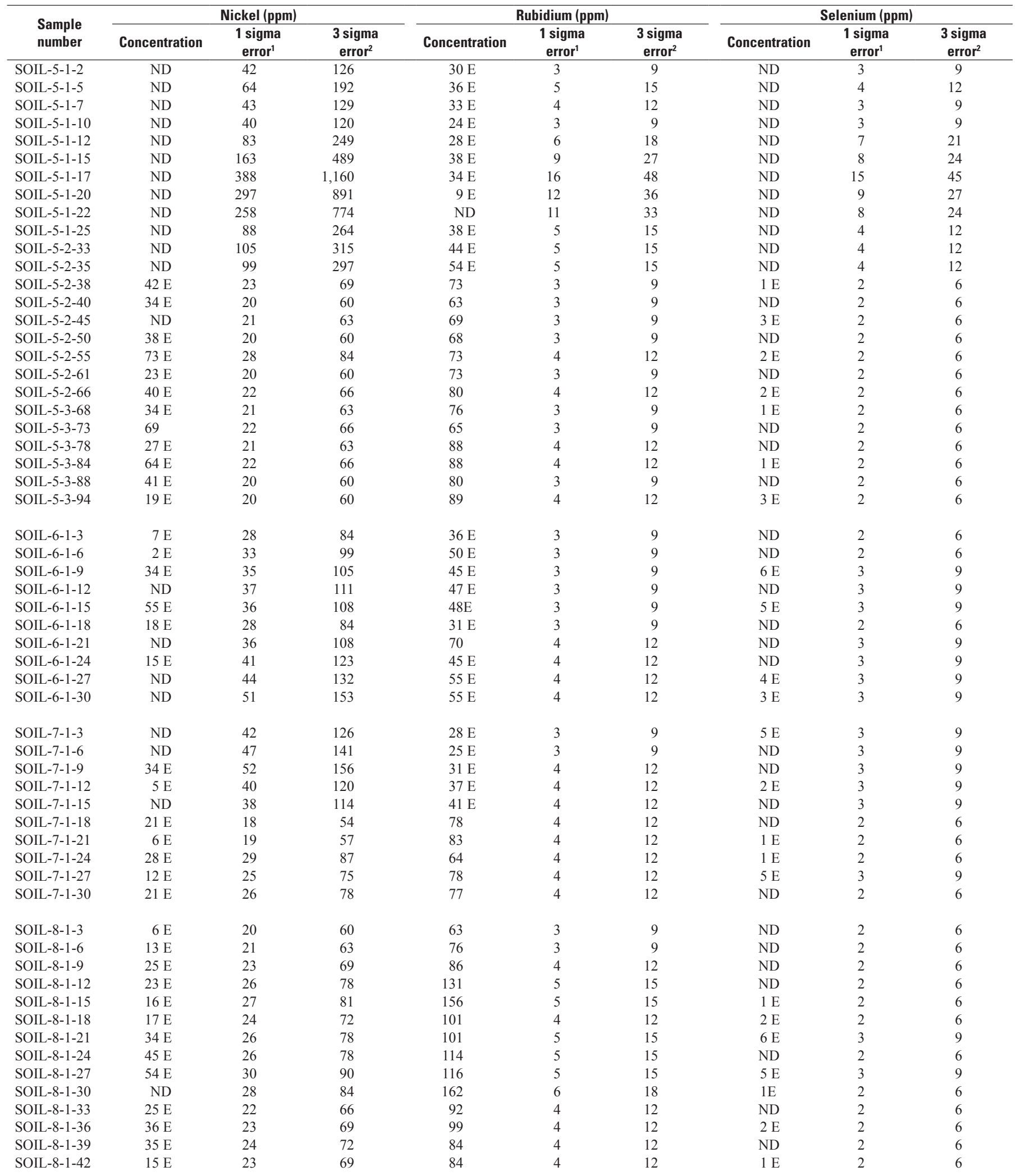


Table G. Results of analyses by X-ray fluorescence spectroscopy of soil samples from Hopewell Furnace National Historic Site, Pennsylvania.-Continued

[Analyses by Cynthia Hall and Martin Helmke of West Chester University and Michael Degnan of the U.S. Geological Survey. cm, centimeters; ppm, parts per million; E, estimated value below the level of detection; ND, not detected; >, greater than]

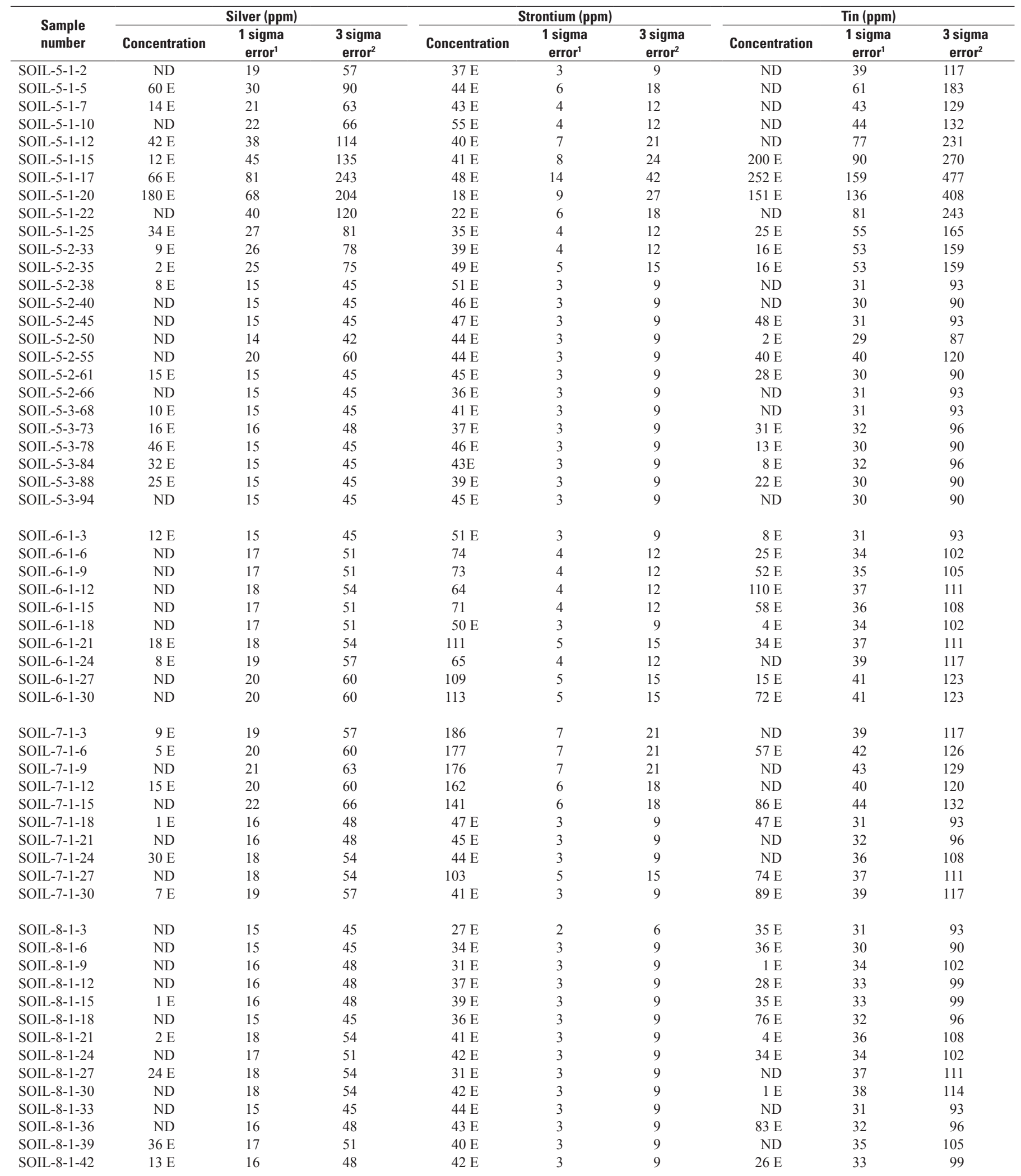


Table G. Results of analyses by X-ray fluorescence spectroscopy of soil samples from Hopewell Furnace National Historic Site, Pennsylvania.-Continued

[Analyses by Cynthia Hall and Martin Helmke of West Chester University and Michael Degnan of the U.S. Geological Survey. cm, centimeters; ppm, parts per million; E, estimated value below the level of detection; ND, not detected; >, greater than]

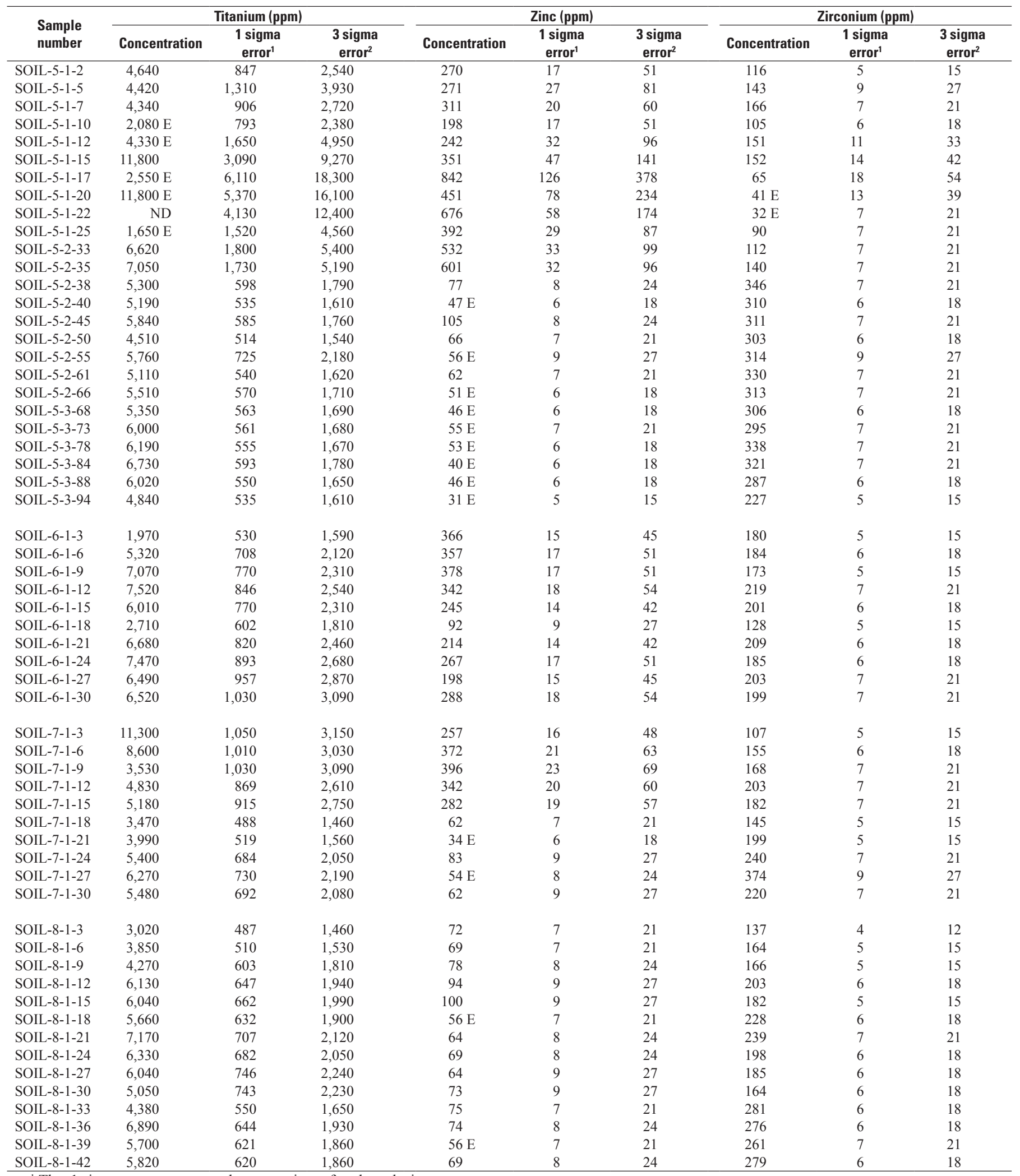

${ }^{1}$ The 1 sigma error represents the uncertainty of each analysis.

${ }^{2}$ The 3 sigma error is the level of detection. Values less than the 3 sigma error are estimated. 
Table H. Results of analysis by X-ray fluorescence spectroscopy of cast iron artifacts in the Hopewell Furnace National Historic Site museum, Pennsylvania.-Continued

[Artifacts are shown on figure 9; analyses by Martin Helmke of West Chester University. All concentrations are in parts per million (ppm); E, estimated value below detection limit; ND, not detected; >, greater than]

\begin{tabular}{|c|c|c|c|c|c|c|c|c|c|c|c|}
\hline \multirow{2}{*}{$\begin{array}{l}\text { Artifact } \\
\text { number }\end{array}$} & \multirow{2}{*}{$\begin{array}{l}\text { Sample } \\
\text { location }\end{array}$} & \multirow{2}{*}{$\begin{array}{c}\text { Reading } \\
\text { number }\end{array}$} & \multicolumn{3}{|c|}{ Antimony (ppm) } & \multicolumn{3}{|c|}{ Arsenic (ppm) } & \multicolumn{3}{|c|}{ Barium (ppm) } \\
\hline & & & Concentration & $\begin{array}{c}1 \text { sigma } \\
\text { error }^{1}\end{array}$ & $\begin{array}{c}3 \text { sigma } \\
\text { error }^{2}\end{array}$ & Concentration & $\begin{array}{c}1 \text { sigma } \\
\text { error }^{1}\end{array}$ & $\begin{array}{c}3 \text { sigma } \\
\text { error }^{2}\end{array}$ & Concentration & $\begin{array}{c}1 \text { sigma } \\
\text { error }^{1}\end{array}$ & $\begin{array}{c}\text { sigma } \\
\text { error }^{2}\end{array}$ \\
\hline Stove 1 & Ash lip & 5 & $128 \mathrm{E}$ & 84 & 252 & 472 & 78 & 234 & $2,060 \mathrm{E}$ & 2,140 & 6,420 \\
\hline Stove 1 & Ash lip & 6 & $8 \mathrm{E}$ & 91 & 273 & ND & 80 & 240 & $2,320 \mathrm{E}$ & 2,430 & 7,290 \\
\hline Stove 1 & Ash lip & 7 & $50 \mathrm{E}$ & 79 & 237 & 500 & 78 & 234 & ND & 1,800 & 5,400 \\
\hline Stove 1 & Top & 8 & ND & 78 & 234 & 411 & 71 & 213 & $1,340 \mathrm{E}$ & 1,970 & 5,910 \\
\hline Stove 1 & Top & 9 & $99 \mathrm{E}$ & 83 & 249 & 565 & 71 & 213 & $2,300 \mathrm{E}$ & 2,070 & 6,210 \\
\hline Stove 1 & Top & 10 & $5 \mathrm{E}$ & 81 & 243 & 497 & 75 & 225 & $1,580 \mathrm{E}$ & 2,040 & 6,120 \\
\hline Stove 2 & Ash lip & 11 & ND & 92 & 276 & 1,330 & 116 & 348 & ND & 2,240 & 6,720 \\
\hline Stove 2 & Ash lip & 12 & $57 \mathrm{E}$ & 99 & 297 & 845 & 107 & 321 & $2,140 \mathrm{E}$ & 2,640 & 7,920 \\
\hline Stove 2 & Ash lip & 13 & ND & 71 & 213 & 995 & 108 & 324 & $299 \mathrm{E}$ & 1,570 & 4,710 \\
\hline Stove 2 & Top & 14 & ND & 89 & 267 & 1,080 & 123 & 369 & ND & 2,180 & 6,540 \\
\hline Stove 2 & Top & 15 & ND & 96 & 288 & 958 & 138 & 414 & $1,770 \mathrm{E}$ & 2,320 & 6,960 \\
\hline Stove 2 & Top & 16 & $70 \mathrm{E}$ & 77 & 231 & 992 & 116 & 348 & ND & 1,790 & 5,370 \\
\hline Stove 3 & Ash lip & 17 & ND & 100 & 300 & 407 & 92 & 276 & $4,250 \mathrm{E}$ & 2,650 & 7,950 \\
\hline Stove 3 & Ash lip & 18 & ND & 104 & 312 & 583 & 91 & 273 & $327 \mathrm{E}$ & 2,860 & 8,580 \\
\hline Stove 3 & Ash lip & 19 & $\mathrm{ND}$ & 94 & 282 & 533 & 79 & 237 & ND & 2,430 & 7,290 \\
\hline Stove 3 & Top & 20 & $\mathrm{ND}$ & 91 & 273 & 659 & 84 & 252 & $908 \mathrm{E}$ & 2,410 & 7,230 \\
\hline Stove 3 & Top & 21 & $10 \mathrm{E}$ & 87 & 261 & 410 & 77 & 231 & $3,760 \mathrm{E}$ & 2,300 & 6,900 \\
\hline Stove 3 & Top & 22 & ND & 89 & 267 & 229 & 68 & 204 & $3,810 \mathrm{E}$ & 2,300 & 6,900 \\
\hline Stove $4^{3}$ & Ash lip & 23 & $26 \mathrm{E}$ & 96 & 288 & 738 & 100 & 300 & ND & 2,440 & 7,320 \\
\hline Stove $4^{3}$ & Ash lip & 24 & ND & 95 & 285 & 709 & 92 & 276 & $2,860 \mathrm{E}$ & 2,470 & 7,410 \\
\hline Stove $4^{3}$ & Ash lip & 25 & ND & 102 & 306 & 820 & 100 & 300 & $5,530 \mathrm{E}$ & 2,760 & 8,280 \\
\hline Stove $4^{3}$ & Top & 26 & $75 \mathrm{E}$ & 89 & 267 & 394 & 77 & 231 & ND & 2,240 & 6,720 \\
\hline Stove $4^{3}$ & Top & 27 & ND & 92 & 276 & 607 & 86 & 258 & $3,500 \mathrm{E}$ & 2,320 & 6,960 \\
\hline Stove $4^{3}$ & Top & 28 & ND & 82 & 246 & 549 & 71 & 213 & $1,820 \mathrm{E}$ & 2,000 & 6,000 \\
\hline Stove 5 & Ash lip & 29 & $\mathrm{ND}$ & 83 & 249 & 341 & 52 & 156 & $3,430 \mathrm{E}$ & 2,030 & 6,090 \\
\hline Stove 5 & Ash lip & 30 & $3 \mathrm{E}$ & 87 & 261 & 223 & 54 & 162 & $2,100 \mathrm{E}$ & 1,950 & 5,850 \\
\hline Stove 5 & Ash lip & 31 & ND & 85 & 255 & 239 & 51 & 153 & $3,140 \mathrm{E}$ & 1,970 & 5,910 \\
\hline Stove 5 & Top & 32 & ND & 84 & 252 & 436 & 62 & 186 & $193 \mathrm{E}$ & 2,030 & 6,090 \\
\hline Stove 5 & Top & 33 & $43 \mathrm{E}$ & 86 & 258 & 328 & 60 & 180 & $2,550 \mathrm{E}$ & 2,150 & 6,450 \\
\hline Stove 5 & Top & 34 & $69 \mathrm{E}$ & 83 & 249 & 416 & 59 & 177 & $2,370 \mathrm{E}$ & 2,010 & 6,030 \\
\hline Stove 6 & Ash lip & 36 & $32 \mathrm{E}$ & 60 & 180 & 462 & 60 & 180 & $1,740 \mathrm{E}$ & 1,020 & 3,060 \\
\hline Stove 6 & Ash lip & 37 & ND & 69 & 207 & 298 & 58 & 174 & $945 \mathrm{E}$ & 1,240 & 3,720 \\
\hline Stove 6 & Ash lip & 38 & ND & 66 & 198 & 386 & 59 & 177 & $1,350 \mathrm{E}$ & 1,210 & 3,630 \\
\hline Stove 6 & Top & 39 & $66 \mathrm{E}$ & 73 & 219 & 440 & 64 & 192 & $1,020 \mathrm{E}$ & 1,590 & 4,770 \\
\hline Stove 6 & Top & 40 & ND & 77 & 231 & 711 & 90 & 270 & $2,680 \mathrm{E}$ & 1,780 & 5,340 \\
\hline Stove 6 & Top & 41 & ND & 79 & 237 & 759 & 86 & 258 & ND & 1,720 & 5,160 \\
\hline Stove 7 & Ash lip & 42 & ND & 88 & 264 & 562 & 75 & 225 & $3,950 \mathrm{E}$ & 2,300 & 6,900 \\
\hline Stove 7 & Ash lip & 43 & $\mathrm{ND}$ & 91 & 273 & 622 & 80 & 240 & $3,750 \mathrm{E}$ & 2,300 & 6,900 \\
\hline Stove 7 & Ash lip & 44 & $\mathrm{ND}$ & 97 & 291 & 549 & 83 & 249 & ND & 2,530 & 7,590 \\
\hline Stove 7 & Top & 45 & $\mathrm{ND}$ & 87 & 261 & 512 & 82 & 246 & $2,530 \mathrm{E}$ & 2,220 & 6,660 \\
\hline Stove 7 & Top & 46 & $\mathrm{ND}$ & 103 & 309 & 681 & 97 & 291 & $1,840 \mathrm{E}$ & 2,780 & 8,340 \\
\hline Stove 7 & Top & 47 & ND & 86 & 258 & 446 & 73 & 219 & $2,470 \mathrm{E}$ & 2,200 & 6,600 \\
\hline Stove 8 & Ash lip & 48 & ND & 90 & 270 & 382 & 84 & 252 & $925 \mathrm{E}$ & 2,150 & 6,450 \\
\hline Stove 8 & Ash lip & 49 & $66 \mathrm{E}$ & 87 & 261 & 640 & 94 & 282 & $3,290 \mathrm{E}$ & 2,150 & 6,450 \\
\hline Stove 8 & Ash lip & 50 & $105 \mathrm{E}$ & 83 & 249 & 208 & 48 & 144 & ND & 1,830 & 5,490 \\
\hline Stove 8 & Top & 52 & $39 \mathrm{E}$ & 75 & 225 & 316 & 59 & 177 & $1,320 \mathrm{E}$ & 1,690 & 5,070 \\
\hline Stove 8 & Top & 53 & ND & 76 & 228 & 243 & 51 & 153 & ND & 1,730 & 5,190 \\
\hline Stove 8 & Top & 54 & $0 \mathrm{E}$ & 75 & 225 & 175 & 58 & 174 & ND & 1,720 & 5,160 \\
\hline Stove 9 & Ash lip & 55 & $85 \mathrm{E}$ & 85 & 255 & 334 & 60 & 180 & ND & 2,050 & 6,150 \\
\hline Stove 9 & Ash lip & 56 & ND & 82 & 246 & 285 & 59 & 177 & ND & 1,890 & 5,670 \\
\hline Stove 9 & Ash lip & 57 & $59 \mathrm{E}$ & 87 & 261 & 380 & 65 & 195 & $684 \mathrm{E}$ & 2,160 & 6,480 \\
\hline Stove 9 & Top & 58 & $45 \mathrm{E}$ & 102 & 306 & 420 & 82 & 246 & $505 \mathrm{E}$ & 2,620 & 7,860 \\
\hline Stove 9 & Top & 59 & $88 \mathrm{E}$ & 87 & 261 & 356 & 64 & 192 & $6,100 \mathrm{E}$ & 2,320 & 6,960 \\
\hline Stove 9 & Top & 60 & $48 \mathrm{E}$ & 95 & 285 & 341 & 71 & 213 & $1,260 \mathrm{E}$ & 2,530 & 7,590 \\
\hline Footed pot & Outside & 61 & ND & 143 & 429 & 1,050 & 178 & 534 & $100 \mathrm{E}$ & 3,840 & 11,500 \\
\hline Footed pot & Outside & 62 & ND & 102 & 306 & 607 & 100 & 300 & $4,050 \mathrm{E}$ & 2,800 & 8,400 \\
\hline Footed pot & Inside & 63 & $26 \mathrm{E}$ & 89 & 267 & 1,180 & 149 & 447 & $3,850 \mathrm{E}$ & 2,200 & 6,600 \\
\hline Footed pot & Inside & 64 & $105 \mathrm{E}$ & 130 & 390 & 1,440 & 242 & 726 & $6,160 \mathrm{E}$ & 3,100 & 9,300 \\
\hline Footed pot & Outside & 65 & $12 \mathrm{E}$ & 89 & 267 & 795 & 134 & 402 & $3,660 \mathrm{E}$ & 2,130 & 6,390 \\
\hline Footed pot & Outside & 66 & ND & 129 & 387 & 922 & 155 & 465 & $553 \mathrm{E}$ & 3,410 & 10,200 \\
\hline Kettle & Outside & 67 & ND & 95 & 285 & ND & 42 & 126 & $6,940 \mathrm{E}$ & 2,360 & 7,080 \\
\hline Kettle & Outside & 68 & $43 \mathrm{E}$ & 103 & 309 & ND & 45 & 135 & $2,120 \mathrm{E}$ & 2,210 & 6,630 \\
\hline Kettle & Outside & 69 & $140 \mathrm{E}$ & 94 & 282 & ND & 45 & 135 & $3,420 \mathrm{E}$ & 2,190 & 6,570 \\
\hline
\end{tabular}


Table H. Results of analysis by X-ray fluorescence spectroscopy of cast iron artifacts in the Hopewell Furnace National Historic Site museum, Pennsylvania._-Continued

[Artifacts are shown on figure 9; analyses by Martin Helmke of West Chester University. All concentrations are in parts per million (ppm); E, estimated value below detection limit; ND, not detected; >, greater than]

\begin{tabular}{|c|c|c|c|c|c|c|c|c|c|c|c|}
\hline \multirow{2}{*}{$\begin{array}{l}\text { Artifact } \\
\text { number }\end{array}$} & \multirow{2}{*}{$\begin{array}{l}\text { Sample } \\
\text { location }\end{array}$} & \multirow{2}{*}{$\begin{array}{l}\text { Reading } \\
\text { number }\end{array}$} & \multicolumn{3}{|c|}{ Bromine (ppm) } & \multicolumn{3}{|c|}{ Cadmium (ppm) } & \multicolumn{3}{|c|}{ Chromium (ppm) } \\
\hline & & & Concentration & $\begin{array}{c}1 \text { sigma } \\
\text { error }^{1}\end{array}$ & $\begin{array}{c}3 \text { sigma } \\
\text { error }^{2}\end{array}$ & Concentration & $\begin{array}{c}1 \text { sigma } \\
\text { error }^{1}\end{array}$ & $\begin{array}{c}3 \text { sigma } \\
\text { error }^{2}\end{array}$ & Concentration & $\begin{array}{c}1 \text { sigma } \\
\text { error }^{1}\end{array}$ & $\begin{array}{c}\text { sigma } \\
\text { error }^{2}\end{array}$ \\
\hline Stove 1 & Ash lip & 5 & 265 & 35 & 105 & ND & 49 & 147 & ND & 611 & 1,830 \\
\hline Stove 1 & Ash lip & 6 & 238 & 41 & 123 & ND & 54 & 162 & ND & 684 & 2,050 \\
\hline Stove 1 & Ash lip & 7 & 233 & 36 & 108 & ND & 46 & 138 & ND & 522 & 1,570 \\
\hline Stove 1 & Top & 8 & 345 & 35 & 105 & ND & 47 & 141 & $346 \mathrm{E}$ & 588 & 1,760 \\
\hline Stove 1 & Top & 9 & 246 & 37 & 111 & $50 \mathrm{E}$ & 48 & 144 & ND & 582 & 1,750 \\
\hline Stove 1 & Top & 10 & 315 & 37 & 111 & ND & 47 & 141 & ND & 573 & 1,720 \\
\hline Stove 2 & Ash lip & 11 & 180 & 41 & 123 & ND & 52 & 156 & ND & 650 & 1,950 \\
\hline Stove 2 & Ash lip & 12 & 291 & 46 & 138 & ND & 57 & 171 & ND & 763 & 2,290 \\
\hline Stove 2 & Ash lip & 13 & 220 & 39 & 117 & ND & 43 & 129 & ND & 455 & 1,370 \\
\hline Stove 2 & Top & 14 & 222 & 42 & 126 & $131 \mathrm{E}$ & 52 & 156 & ND & 638 & 1,910 \\
\hline Stove 2 & Top & 15 & 201 & 48 & 144 & $3 \mathrm{E}$ & 56 & 168 & ND & 663 & 1,990 \\
\hline Stove 2 & Top & 16 & 172 & 41 & 123 & ND & 47 & 141 & ND & 532 & 1,600 \\
\hline Stove 3 & Ash lip & 17 & 415 & 42 & 126 & ND & 56 & 168 & ND & 758 & 2,270 \\
\hline Stove 3 & Ash lip & 18 & 404 & 47 & 141 & $1 \mathrm{E}$ & 60 & 180 & ND & 829 & 2,490 \\
\hline Stove 3 & Ash lip & 19 & 301 & 39 & 117 & ND & 53 & 159 & ND & 715 & 2,150 \\
\hline Stove 3 & Top & 20 & 386 & 40 & 120 & $6 \mathrm{E}$ & 53 & 159 & ND & 706 & 2,120 \\
\hline Stove 3 & Top & 21 & 333 & 35 & 105 & $16 \mathrm{E}$ & 52 & 156 & ND & 640 & 1,920 \\
\hline Stove 3 & Top & 22 & 374 & 34 & 102 & ND & 51 & 153 & ND & 651 & 1,950 \\
\hline Stove $4^{3}$ & Ash lip & 23 & 349 & 48 & 144 & ND & 56 & 168 & ND & 718 & 2,150 \\
\hline Stove $4^{3}$ & Ash lip & 24 & 287 & 43 & 129 & ND & 54 & 162 & $326 \mathrm{E}$ & 739 & 2,220 \\
\hline Stove $4^{3}$ & Ash lip & 25 & 362 & 47 & 141 & $126 \mathrm{E}$ & 60 & 180 & ND & 798 & 2,390 \\
\hline Stove $4^{3}$ & Top & 26 & 367 & 42 & 126 & ND & 52 & 156 & $369 \mathrm{E}$ & 675 & 2,030 \\
\hline Stove $4^{3}$ & Top & 27 & 340 & 42 & 126 & ND & 51 & 153 & ND & 680 & 2,040 \\
\hline Stove $4^{3}$ & Top & 28 & 257 & 34 & 102 & ND & 47 & 141 & ND & 560 & 1,680 \\
\hline Stove 5 & Ash lip & 29 & 297 & 33 & 99 & $69 \mathrm{E}$ & 47 & 141 & $590 \mathrm{E}$ & 602 & 1,810 \\
\hline Stove 5 & Ash lip & 30 & 301 & 35 & 105 & ND & 49 & 147 & ND & 557 & 1,670 \\
\hline Stove 5 & Ash lip & 31 & 324 & 32 & 96 & ND & 48 & 144 & ND & 556 & 1,670 \\
\hline Stove 5 & Top & 32 & 328 & 35 & 105 & $25 \mathrm{E}$ & 47 & 141 & $507 \mathrm{E}$ & 614 & 1,840 \\
\hline Stove 5 & Top & 33 & 344 & 35 & 105 & ND & 51 & 153 & ND & 622 & 1,870 \\
\hline Stove 5 & Top & 34 & 336 & 31 & 93 & ND & 48 & 144 & ND & 590 & 1,770 \\
\hline Stove 6 & Ash lip & 36 & 89 & 27 & 81 & $57 \mathrm{E}$ & 36 & 108 & $1 \mathrm{E}$ & 290 & 870 \\
\hline Stove 6 & Ash lip & 37 & 161 & 26 & 78 & $83 \mathrm{E}$ & 40 & 120 & ND & 351 & 1,050 \\
\hline Stove 6 & Ash lip & 38 & 186 & 27 & 81 & ND & 38 & 114 & ND & 342 & 1,030 \\
\hline Stove 6 & Top & 39 & 225 & 30 & 90 & ND & 43 & 129 & ND & 454 & 1,360 \\
\hline Stove 6 & Top & 40 & 223 & 35 & 105 & ND & 46 & 138 & ND & 514 & 1,540 \\
\hline Stove 6 & Top & 41 & 193 & 33 & 99 & $5 \mathrm{E}$ & 46 & 138 & ND & 489 & 1,470 \\
\hline Stove 7 & Ash lip & 42 & 341 & 39 & 117 & $66 \mathrm{E}$ & 52 & 156 & ND & 666 & 2,000 \\
\hline Stove 7 & Ash lip & 43 & 322 & 36 & 108 & $34 \mathrm{E}$ & 52 & 156 & ND & 668 & 2,000 \\
\hline Stove 7 & Ash lip & 44 & 405 & 46 & 138 & $5 \mathrm{E}$ & 56 & 168 & ND & 751 & 2,250 \\
\hline Stove 7 & Top & 45 & 270 & 37 & 111 & ND & 50 & 150 & ND & 642 & 1,930 \\
\hline Stove 7 & Top & 46 & 406 & 45 & 135 & ND & 58 & 174 & ND & 809 & 2,430 \\
\hline Stove 7 & Top & 47 & 311 & 38 & 114 & ND & 52 & 156 & ND & 617 & 1,850 \\
\hline Stove 8 & Ash lip & 48 & 344 & 37 & 111 & $116 \mathrm{E}$ & 52 & 156 & $69 \mathrm{E}$ & 641 & 1,920 \\
\hline Stove 8 & Ash lip & 49 & 228 & 40 & 120 & ND & 51 & 153 & $941 \mathrm{E}$ & 640 & 1,920 \\
\hline Stove 8 & Ash lip & 50 & 278 & 28 & 84 & ND & 47 & 141 & ND & 553 & 1,660 \\
\hline Stove 8 & Top & 52 & 207 & 30 & 90 & $6 \mathrm{E}$ & 42 & 126 & ND & 493 & 1,480 \\
\hline Stove 8 & Top & 53 & 269 & 28 & 84 & ND & 44 & 132 & $602 \mathrm{E}$ & 536 & 1,610 \\
\hline Stove 8 & Top & 54 & 251 & 29 & 87 & $67 \mathrm{E}$ & 44 & 132 & ND & 505 & 1,520 \\
\hline Stove 9 & Ash lip & 55 & 332 & 38 & 114 & ND & 51 & 153 & ND & 596 & 1,790 \\
\hline Stove 9 & Ash lip & 56 & 285 & 34 & 102 & $115 \mathrm{E}$ & 49 & 147 & ND & 556 & 1,670 \\
\hline Stove 9 & Ash lip & 57 & 311 & 35 & 105 & $54 \mathrm{E}$ & 51 & 153 & ND & 640 & 1,920 \\
\hline Stove 9 & Top & 58 & 429 & 42 & 126 & $26 \mathrm{E}$ & 59 & 177 & ND & 760 & 2,280 \\
\hline Stove 9 & Top & 59 & 333 & 36 & 108 & ND & 50 & 150 & ND & 639 & 1,920 \\
\hline Stove 9 & Top & 60 & 382 & 45 & 135 & ND & 54 & 162 & ND & 720 & 2,160 \\
\hline Footed pot & Outside & 61 & 290 & 63 & 189 & $70 \mathrm{E}$ & 82 & 246 & ND & 1,150 & 3,450 \\
\hline Footed pot & Outside & 62 & 396 & 44 & 132 & ND & 57 & 171 & ND & 793 & 2,380 \\
\hline Footed pot & Inside & 63 & 142 & 46 & 138 & ND & 53 & 159 & ND & 631 & 1,890 \\
\hline Footed pot & Inside & 64 & $157 \mathrm{E}$ & 69 & 207 & $5 \mathrm{E}$ & 76 & 228 & ND & 871 & 2,610 \\
\hline Footed pot & Outside & 65 & 183 & 43 & 129 & ND & 52 & 156 & ND & 616 & 1,850 \\
\hline Footed pot & Outside & 66 & 296 & 55 & 165 & $44 \mathrm{E}$ & 73 & 219 & ND & 992 & 2,980 \\
\hline Kettle & Outside & 67 & 353 & 34 & 102 & ND & 57 & 171 & ND & 641 & 1,920 \\
\hline Kettle & Outside & 68 & 357 & 34 & 102 & ND & 59 & 177 & ND & 639 & 1,920 \\
\hline Kettle & Outside & 69 & 373 & 31 & 93 & ND & 56 & 168 & ND & 626 & 1,880 \\
\hline
\end{tabular}


Table H. Results of analysis by X-ray fluorescence spectroscopy of cast iron artifacts in the Hopewell Furnace National Historic Site museum, Pennsylvania.-Continued

[Artifacts are shown on figure 9; analyses by Martin Helmke of West Chester University. All concentrations are in parts per million (ppm); E, estimated value below detection limit; ND, not detected; >, greater than]

\begin{tabular}{|c|c|c|c|c|c|c|c|c|c|c|c|}
\hline \multirow{2}{*}{$\begin{array}{l}\text { Artifact } \\
\text { number }\end{array}$} & \multirow{2}{*}{$\begin{array}{l}\text { Sample } \\
\text { location }\end{array}$} & \multirow{2}{*}{$\begin{array}{c}\text { Reading } \\
\text { number }\end{array}$} & \multicolumn{3}{|c|}{ Cobalt (ppm) } & \multicolumn{3}{|c|}{ Copper (ppm) } & \multicolumn{3}{|c|}{ Gold (ppm) } \\
\hline & & & Concentration & $\begin{array}{c}1 \text { sigma } \\
\text { error }^{1}\end{array}$ & $\begin{array}{c}3 \text { sigma } \\
\text { error }^{2}\end{array}$ & Concentration & $\begin{array}{c}1 \text { sigma } \\
\text { error }^{1}\end{array}$ & $\begin{array}{c}3 \text { sigma } \\
\text { error }^{2}\end{array}$ & Concentration & $\begin{array}{c}1 \text { sigma } \\
\text { error }^{1}\end{array}$ & $\begin{array}{c}3 \text { sigma } \\
\text { error }^{2}\end{array}$ \\
\hline $\begin{array}{l}\text { Stove } 1 \\
\text {. }\end{array}$ & Ash lip & 5 & 11,900 & 2,150 & 6,450 & 1,590 & 127 & 381 & 252 & 19 & 57 \\
\hline Stove 1 & Ash lip & 6 & 12,100 & 2,440 & 7,320 & 2,270 & 165 & 495 & 327 & 21 & 63 \\
\hline Stove 1 & Ash lip & 7 & 17,200 & 1,920 & 5,760 & 1,510 & 115 & 345 & 215 & 20 & 60 \\
\hline Stove 1 & Top & 8 & 13,300 & 2,000 & 6,000 & 1,810 & 130 & 390 & 267 & 20 & 60 \\
\hline Stove 1 & Top & 9 & 12,000 & 2,070 & 6,210 & 1,430 & 120 & 360 & 266 & 21 & 63 \\
\hline Stove 1 & Top & 10 & 11,300 & 2,030 & 6,090 & 1,870 & 135 & 405 & 236 & 20 & 60 \\
\hline Stove 2 & Ash lip & 11 & 16,000 & 2,360 & 7,080 & 2,210 & 159 & 477 & 234 & 25 & 75 \\
\hline Stove 2 & Ash lip & 12 & 16,200 & 2,690 & 8,070 & 4,240 & 254 & 762 & 341 & 29 & 87 \\
\hline Stove 2 & Ash lip & 13 & 17,700 & 1,700 & 5,100 & 2,060 & 126 & 378 & 160 & 23 & 69 \\
\hline Stove 2 & Top & 14 & 12,500 & 2,280 & 6,840 & 3,310 & 200 & 600 & 214 & 24 & 72 \\
\hline Stove 2 & Top & 15 & 11,000 & 2,320 & 6,960 & 2,060 & 165 & 495 & 193 & 29 & 87 \\
\hline Stove 2 & Top & 16 & 13,100 & 1,900 & 5,700 & 2,070 & 138 & 414 & 170 & 23 & 69 \\
\hline Stove 3 & Ash lip & 17 & 16,700 & 2,700 & 8,100 & 4,440 & 263 & 789 & 372 & 28 & 84 \\
\hline Stove 3 & Ash lip & 18 & $5,600 \mathrm{E}$ & 2,870 & 8,610 & 4,790 & 292 & 876 & 400 & 30 & 90 \\
\hline Stove 3 & Ash lip & 19 & 12,200 & 2,480 & 7,440 & 4,750 & 264 & 792 & 341 & 24 & 72 \\
\hline Stove 3 & Top & 20 & 14,400 & 2,450 & 7,350 & 2,900 & 189 & 567 & 306 & 24 & 72 \\
\hline Stove 3 & Top & 21 & 9,280 & 2,270 & 6,810 & 2,620 & 173 & 519 & 305 & 21 & 63 \\
\hline Stove 3 & Top & 22 & 8,090 & 2,240 & 6,720 & 2,850 & 180 & 540 & 321 & 21 & 63 \\
\hline Stove $4^{3}$ & Ash lip & 23 & 10,200 & 2,520 & 7,560 & ND & 78 & 234 & 296 & 26 & 78 \\
\hline Stove $4^{3}$ & Ash lip & 24 & $5,120 \mathrm{E}$ & 2,440 & 7,320 & ND & 71 & 213 & 334 & 27 & 81 \\
\hline Stove $4^{3}$ & Ash lip & 25 & 8,810 & 2,680 & 8,040 & ND & 84 & 252 & 349 & 29 & 87 \\
\hline Stove $4^{3}$ & Top & 26 & 10,500 & 2,270 & 6,810 & ND & 70 & 210 & 301 & 23 & 69 \\
\hline Stove $4^{3}$ & Top & 27 & 8,360 & 2,280 & 6,840 & ND & 73 & 219 & 290 & 23 & 69 \\
\hline Stove $4^{3}$ & Top & 28 & $4,870 \mathrm{E}$ & 1,950 & 5,850 & ND & 67 & 201 & 248 & 20 & 60 \\
\hline Stove 5 & Ash lip & 29 & 8,720 & 1,980 & 5,940 & 1,580 & 124 & 372 & 261 & 18 & 54 \\
\hline Stove 5 & Ash lip & 30 & 7,030 & 1,930 & 5,790 & 1,460 & 120 & 360 & 256 & 18 & 54 \\
\hline Stove 5 & Ash lip & 31 & 9,790 & 1,940 & 5,820 & 1,360 & 116 & 348 & 247 & 16 & 48 \\
\hline Stove 5 & Top & 32 & 8,940 & 2,040 & 6,120 & 1,850 & 136 & 408 & 264 & 20 & 60 \\
\hline Stove 5 & Top & 33 & 13,800 & 2,160 & 6,480 & 1,930 & 143 & 429 & 311 & 22 & 66 \\
\hline Stove 5 & Top & 34 & 9,590 & 2,010 & 6,030 & 1,180 & 112 & 336 & 263 & 19 & 57 \\
\hline Stove 6 & Ash lip & 36 & 11,300 & 1,010 & 3,030 & 215 & 45 & 135 & 81 & 15 & 45 \\
\hline Stove 6 & Ash lip & 37 & 8,930 & 1,230 & 3,690 & $99 \mathrm{E}$ & 48 & 144 & 115 & 13 & 39 \\
\hline Stove 6 & Ash lip & 38 & 13,700 & 1,240 & 3,720 & 267 & 52 & 156 & 96 & 13 & 39 \\
\hline Stove 6 & Top & 39 & 8,000 & 1,590 & 4,770 & $52 \mathrm{E}$ & 56 & 168 & 190 & 16 & 48 \\
\hline Stove 6 & Top & 40 & 10,200 & 1,760 & 5,280 & $53 \mathrm{E}$ & 61 & 183 & 174 & 19 & 57 \\
\hline Stove 6 & Top & 41 & 11,400 & 1,830 & 5,490 & ND & 58 & 174 & 203 & 21 & 63 \\
\hline Stove 7 & Ash lip & 42 & 7,960 & 2,270 & 6,810 & 2,700 & 177 & 531 & 319 & 24 & 72 \\
\hline Stove 7 & Ash lip & 43 & 10,200 & 2,280 & 6,840 & 2,240 & 160 & 480 & 294 & 23 & 69 \\
\hline Stove 7 & Ash lip & 44 & 9,740 & 2,610 & 7,830 & 3,480 & 223 & 669 & 334 & 24 & 72 \\
\hline Stove 7 & Top & 45 & 8,540 & 2,190 & 6,570 & 1,670 & 135 & 405 & 295 & 23 & 69 \\
\hline Stove 7 & Top & 46 & 8,520 & 2,750 & 8,250 & 1,750 & 159 & 477 & 380 & 29 & 87 \\
\hline Stove 7 & Top & 47 & 12,300 & 2,220 & 6,660 & 1,970 & 145 & 435 & 277 & 20 & 60 \\
\hline Stove 8 & Ash lip & 48 & 17,100 & 2,250 & 6,750 & 2,140 & 152 & 456 & 289 & 23 & 69 \\
\hline Stove 8 & Ash lip & 49 & 13,200 & 2,120 & 6,360 & 3,810 & 212 & 636 & 257 & 23 & 69 \\
\hline Stove 8 & Ash lip & 50 & 7,090 & 1,880 & 5,640 & 1,860 & 129 & 387 & 271 & 17 & 51 \\
\hline Stove 8 & Top & 52 & 10,700 & 1,710 & 5,130 & 1,310 & 103 & 309 & 213 & 17 & 51 \\
\hline Stove 8 & Top & 53 & 11,000 & 1,800 & 5,400 & 1,970 & 129 & 387 & 256 & 17 & 51 \\
\hline Stove 8 & Top & 54 & 7,900 & 1,770 & 5,310 & 4,560 & 218 & 654 & 241 & 17 & 51 \\
\hline Stove 9 & Ash lip & 55 & 14,600 & 2,180 & 6,540 & 1,030 & 108 & 324 & 281 & 21 & 63 \\
\hline Stove 9 & Ash lip & 56 & 17,300 & 2,050 & 6,150 & 929 & 99 & 297 & 243 & 18 & 54 \\
\hline Stove 9 & Ash lip & 57 & 13,700 & 2,220 & 6,660 & 1,030 & 109 & 327 & 299 & 22 & 66 \\
\hline Stove 9 & Top & 58 & 10,100 & 2,680 & 8,040 & 1,730 & 154 & 462 & 392 & 29 & 87 \\
\hline Stove 9 & Top & 59 & 12,600 & 2,280 & 6,840 & 1,490 & 129 & 387 & 306 & 21 & 63 \\
\hline Stove 9 & Top & 60 & 9,250 & 2,550 & 7,650 & 1,610 & 145 & 435 & 350 & 24 & 72 \\
\hline Footed pot & Outside & 61 & $1,760 \mathrm{E}$ & 3,850 & 11,600 & ND & 105 & 315 & 373 & 44 & 132 \\
\hline Footed pot & Outside & 62 & ND & 2,750 & 8,250 & ND & 79 & 237 & 381 & 29 & 87 \\
\hline Footed pot & Inside & 63 & 7,640 & 2,160 & 6,480 & ND & 64 & 192 & 193 & 29 & 87 \\
\hline Footed pot & Inside & 64 & $5,390 \mathrm{E}$ & 2,960 & 8,880 & ND & 90 & 270 & 178 & 45 & 135 \\
\hline Footed pot & Outside & 65 & $4,310 \mathrm{E}$ & 2,080 & 6,240 & ND & 64 & 192 & 222 & 28 & 84 \\
\hline Footed pot & Outside & 66 & ND & 3,420 & 10,300 & ND & 98 & 294 & 385 & 43 & 129 \\
\hline Kettle & Outside & 67 & ND & 2,130 & 6,390 & ND & 61 & 183 & 259 & 21 & 63 \\
\hline Kettle & Outside & 68 & ND & 2,120 & 6,360 & ND & 59 & 177 & 323 & 21 & 63 \\
\hline Kettle & Outside & 69 & ND & 2,080 & 6,240 & ND & 54 & 162 & 264 & 19 & 57 \\
\hline
\end{tabular}


Table H. Results of analysis by X-ray fluorescence spectroscopy of cast iron artifacts in the Hopewell Furnace National Historic Site museum, Pennsylvania.-Continued

[Artifacts are shown on figure 9; analyses by Martin Helmke of West Chester University. All concentrations are in parts per million (ppm); E, estimated value below detection limit; ND, not detected; >, greater than]

\begin{tabular}{|c|c|c|c|c|c|c|c|c|c|c|c|}
\hline \multirow[b]{2}{*}{$\begin{array}{l}\text { Artifact } \\
\text { number }\end{array}$} & \multirow[b]{2}{*}{$\begin{array}{l}\text { Sample } \\
\text { location }\end{array}$} & \multirow[b]{2}{*}{$\begin{array}{c}\text { Reading } \\
\text { number }\end{array}$} & \multicolumn{3}{|c|}{ Iron (ppm) } & \multicolumn{3}{|c|}{ Lead (ppm) } & \multicolumn{3}{|c|}{ Manganese (ppm) } \\
\hline & & & Concentration & $\begin{array}{c}1 \text { sigma } \\
\text { error }^{1}\end{array}$ & $\begin{array}{c}3 \text { sigma } \\
\text { error }^{2}\end{array}$ & Concentration & $\begin{array}{c}1 \text { sigma } \\
\text { error }^{1}\end{array}$ & $\begin{array}{c}3 \text { sigma } \\
\text { error }^{2}\end{array}$ & Concentration & $\begin{array}{c}1 \text { sigma } \\
\text { error }^{1}\end{array}$ & $\begin{array}{c}3 \text { sigma } \\
\text { error }^{2}\end{array}$ \\
\hline Stove 1 & Ash lip & 5 & $>900,000$ & 96,700 & 290,000 & 574 & 88 & 264 & ND & 858 & 2,570 \\
\hline Stove 1 & Ash lip & 6 & $>900,000$ & 119,000 & 357,000 & 1,120 & 102 & 306 & ND & 958 & 2,870 \\
\hline Stove 1 & Ash lip & 7 & $>900,000$ & 75,500 & 227,000 & 1,090 & 89 & 267 & ND & 751 & 2,250 \\
\hline Stove 1 & Top & 8 & $>900,000$ & 85,000 & 255,000 & 560 & 80 & 240 & ND & 795 & 2,390 \\
\hline Stove 1 & Top & 9 & $>900,000$ & 90,600 & 272,000 & 230 & 76 & 228 & ND & 815 & 2,450 \\
\hline Stove 1 & Top & 10 & $>900,000$ & 88,000 & 264,000 & 596 & 83 & 249 & ND & 817 & 2,450 \\
\hline Stove 2 & Ash lip & 11 & $>900,000$ & 109,000 & 327,000 & 1,350 & 115 & 345 & $226 \mathrm{E}$ & 954 & 2,860 \\
\hline Stove 2 & Ash lip & 12 & $>900,000$ & 135,000 & 405,000 & 838 & 115 & 345 & ND & 1,080 & 3,240 \\
\hline Stove 2 & Ash lip & 13 & $>900,000$ & 60,200 & 181,000 & 3,150 & 142 & 426 & $1,870 \mathrm{E}$ & 687 & 2,060 \\
\hline Stove 2 & Top & 14 & $>900,000$ & 105,000 & 315,000 & 2,330 & 146 & 438 & ND & 935 & 2,810 \\
\hline Stove 2 & Top & 15 & $>900,000$ & 98,600 & 296,000 & 2,960 & 180 & 540 & ND & 933 & 2,800 \\
\hline Stove 2 & Top & 16 & $>900,000$ & 77,000 & 231,000 & 3,090 & 153 & 459 & $1,850 \mathrm{E}$ & 795 & 2,390 \\
\hline Stove 3 & Ash lip & 17 & $>900,000$ & 135,000 & 405,000 & 577 & 110 & 330 & ND & 1,020 & 3,060 \\
\hline Stove 3 & Ash lip & 18 & $>900,000$ & 159,000 & 477,000 & ND & 108 & 324 & ND & 1,170 & 3,510 \\
\hline Stove 3 & Ash lip & 19 & $>900,000$ & 122,000 & 366,000 & $4 \mathrm{E}$ & 91 & 273 & ND & 981 & 2,940 \\
\hline Stove 3 & Top & 20 & $>900,000$ & 118,000 & 354,000 & $217 \mathrm{E}$ & 92 & 276 & ND & 959 & 2,880 \\
\hline Stove 3 & Top & 21 & $>900,000$ & 108,000 & 324,000 & 355 & 89 & 267 & ND & 927 & 2,780 \\
\hline Stove 3 & Top & 22 & $>900,000$ & 107,000 & 321,000 & $166 \mathrm{E}$ & 85 & 255 & ND & 930 & 2,790 \\
\hline Stove $4^{3}$ & Ash lip & 23 & $>900,000$ & 127,000 & 381,000 & 806 & 110 & 330 & $1,730 \mathrm{E}$ & 1,070 & 3,210 \\
\hline Stove $4^{3}$ & Ash lip & 24 & $>900,000$ & 124,000 & 372,000 & 464 & 100 & 300 & $177 \mathrm{E}$ & 1,040 & 3120 \\
\hline Stove $4^{3}$ & Ash lip & 25 & $>900,000$ & 141,000 & 423,000 & 447 & 105 & 315 & 5,110 & 1,200 & 3600 \\
\hline Stove $4^{3}$ & Top & 26 & $>900,000$ & 107,000 & 321,000 & 401 & 89 & 267 & 8,040 & 1,080 & 3240 \\
\hline Stove $4^{3}$ & Top & 27 & $>900,000$ & 109,000 & 327,000 & 535 & 94 & 282 & 10,700 & 1,150 & 3450 \\
\hline Stove $4^{3}$ & Top & 28 & $>900,000$ & 86,300 & 259,000 & 325 & 76 & 228 & 6,900 & 937 & 2,810 \\
\hline Stove 5 & Ash lip & 29 & $>900,000$ & 86,000 & 258,000 & ND & 63 & 189 & 2,840 & 864 & 2,590 \\
\hline Stove 5 & Ash lip & 30 & $>900,000$ & 83,100 & 249,000 & $35 \mathrm{E}$ & 66 & 198 & 2,590 & 844 & 2,530 \\
\hline Stove 5 & Ash lip & 31 & $>900,000$ & 82,100 & 246,000 & ND & 63 & 189 & $1,510 \mathrm{E}$ & 823 & 2,470 \\
\hline Stove 5 & Top & 32 & $>900,000$ & 90,600 & 272,000 & ND & 71 & 213 & $2,620 \mathrm{E}$ & 887 & 2,660 \\
\hline Stove 5 & Top & 33 & $>900,000$ & 96,100 & 288,000 & ND & 72 & 216 & $2,200 \mathrm{E}$ & 911 & 2,730 \\
\hline Stove 5 & Top & 34 & $>900,000$ & 86,900 & 261,000 & ND & 67 & 201 & $1,860 \mathrm{E}$ & 859 & 2,580 \\
\hline Stove 6 & Ash lip & 36 & $>750,000$ & 25,100 & 75,300 & 1,490 & 68 & 204 & 3,220 & 451 & 1,350 \\
\hline Stove 6 & Ash lip & 37 & $>900,000$ & 37,400 & 112,000 & 1,060 & 65 & 195 & 2,430 & 541 & 1,620 \\
\hline Stove 6 & Ash lip & 38 & $>900,000$ & 35,300 & 106,000 & 1,150 & 66 & 198 & $1,190 \mathrm{E}$ & 501 & 1,500 \\
\hline Stove 6 & Top & 39 & $>900,000$ & 60,500 & 182,000 & 700 & 69 & 207 & ND & 642 & 1,930 \\
\hline Stove 6 & Top & 40 & $>900,000$ & 69,900 & 210,000 & 1,700 & 104 & 312 & $895 \mathrm{E}$ & 739 & 2,220 \\
\hline Stove 6 & Top & 41 & $>900,000$ & 73,700 & 221,000 & 1,210 & 92 & 276 & $877 \mathrm{E}$ & 759 & 2,280 \\
\hline Stove 7 & Ash lip & 42 & $>900,000$ & 108,000 & 324,000 & $67 \mathrm{E}$ & 83 & 249 & $2,330 \mathrm{E}$ & 981 & 2,940 \\
\hline Stove 7 & Ash lip & 43 & $>900,000$ & 107,000 & 321,000 & 279 & 86 & 258 & 7,000 & 1,060 & 3,180 \\
\hline Stove 7 & Ash lip & 44 & $>900,000$ & 135,000 & 405,000 & $7 \mathrm{E}$ & 96 & 288 & 4,050 & 1,150 & 3450 \\
\hline Stove 7 & Top & 45 & $>900,000$ & 101,000 & 303,000 & 626 & 92 & 276 & $1,590 \mathrm{E}$ & 935 & 2,810 \\
\hline Stove 7 & Top & 46 & $>900,000$ & 148,000 & 444,000 & $282 \mathrm{E}$ & 108 & 324 & 5,340 & 1,240 & 3,720 \\
\hline Stove 7 & Top & 47 & $>900,000$ & 101,000 & 303,000 & 253 & 83 & 249 & $1,790 \mathrm{E}$ & 934 & 2,800 \\
\hline Stove 8 & Ash lip & 48 & $>900,000$ & 98,100 & 294,000 & 950 & 99 & 297 & $700 \mathrm{E}$ & 908 & 2,720 \\
\hline Stove 8 & Ash lip & 49 & $>900,000$ & 92,200 & 277,000 & 1,360 & 107 & 321 & $2,080 \mathrm{E}$ & 895 & 2,690 \\
\hline Stove 8 & Ash lip & 50 & $>900,000$ & 80,000 & 240,000 & ND & 63 & 189 & $1,570 \mathrm{E}$ & 806 & 2,420 \\
\hline Stove 8 & Top & 52 & $>900,000$ & 66,300 & 199,000 & 468 & 67 & 201 & ND & 685 & 2,060 \\
\hline Stove 8 & Top & 53 & $>900,000$ & 72,200 & 216,000 & $1 \mathrm{E}$ & 62 & 186 & ND & 728 & 2,180 \\
\hline Stove 8 & Top & 54 & $>900,000$ & 71,800 & 215,000 & 370 & 69 & 207 & ND & 732 & 2,200 \\
\hline Stove 9 & Ash lip & 55 & $>900,000$ & 95,700 & 287,000 & ND & 73 & 219 & $193 \mathrm{E}$ & 882 & 2,650 \\
\hline Stove 9 & Ash lip & 56 & $>900,000$ & 83,500 & 251,000 & $117 \mathrm{E}$ & 69 & 207 & $254 \mathrm{E}$ & 815 & 2,450 \\
\hline Stove 9 & Ash lip & 57 & $>900,000$ & 99,600 & 299,000 & ND & 76 & 228 & ND & 898 & 2,690 \\
\hline Stove 9 & Top & 58 & $>900,000$ & 140,000 & 420,000 & $54 \mathrm{E}$ & 99 & 297 & ND & 1,110 & 3,330 \\
\hline Stove 9 & Top & 59 & $>900,000$ & 106,000 & 318,000 & ND & 80 & 240 & $2,240 \mathrm{E}$ & 966 & 2,900 \\
\hline Stove 9 & Top & 60 & $>900,000$ & 130,000 & 390,000 & ND & 91 & 273 & ND & 1,050 & 3,150 \\
\hline Footed pot & Outside & 61 & $>900,000$ & 217,000 & 651,000 & 1,550 & 198 & 594 & $2,620 \mathrm{E}$ & 1,690 & 5,070 \\
\hline Footed pot & Outside & 62 & $>900,000$ & 152,000 & 456,000 & 469 & 112 & 336 & $3,380 \mathrm{E}$ & 1,220 & 3,660 \\
\hline Footed pot & Inside & 63 & $>900,000$ & 97,300 & 292,000 & 4,410 & 221 & 663 & $1,620 \mathrm{E}$ & 926 & 2,780 \\
\hline Footed pot & Inside & 64 & $>900,000$ & 135,000 & 405,000 & 6,270 & 415 & 1,250 & ND & 1,250 & 3,750 \\
\hline Footed pot & Outside & 65 & $>900,000$ & 92,800 & 278,000 & 3,890 & 200 & 600 & $725 \mathrm{E}$ & 889 & 2,670 \\
\hline Footed pot & Outside & 66 & $>900,000$ & 19,000 & 57,000 & 1,550 & 177 & 531 & $1,220 \mathrm{E}$ & 1,490 & 4,470 \\
\hline Kettle & Outside & 67 & $>900,000$ & 97,000 & 291,000 & 401 & 54 & 162 & 6,120 & 1,040 & 3,120 \\
\hline Kettle & Outside & 68 & $>900,000$ & 96,000 & 288,000 & 536 & 60 & 180 & 5,480 & 1,020 & 3,060 \\
\hline Kettle & Outside & 69 & $>900,000$ & 93,100 & 279,000 & 540 & 59 & 177 & 5,230 & 988 & 2,960 \\
\hline
\end{tabular}


Table H. Results of analysis by X-ray fluorescence spectroscopy of cast iron artifacts in the Hopewell Furnace National Historic Site museum, Pennsylvania.-Continued

[Artifacts are shown on figure 9; analyses by Martin Helmke of West Chester University. All concentrations are in parts per million (ppm); E, estimated value below detection limit; ND, not detected; >, greater than]

\begin{tabular}{|c|c|c|c|c|c|c|c|c|c|c|c|}
\hline \multirow{2}{*}{$\begin{array}{l}\text { Artifact } \\
\text { number }\end{array}$} & \multirow[b]{2}{*}{$\begin{array}{c}\text { Sample } \\
\text { location }\end{array}$} & \multirow{2}{*}{$\begin{array}{c}\text { Reading } \\
\text { number }\end{array}$} & \multicolumn{3}{|c|}{ Mercury (ppm) } & \multicolumn{3}{|c|}{ Molybdenum (ppm) } & \multicolumn{3}{|c|}{ Nickel (ppm) } \\
\hline & & & Concentration & $\begin{array}{c}1 \text { sigma } \\
\text { error }^{1}\end{array}$ & $\begin{array}{c}3 \text { sigma } \\
\text { error }^{2}\end{array}$ & Concentration & $\begin{array}{c}1 \text { sigma } \\
\text { error }^{1}\end{array}$ & $\begin{array}{c}3 \text { sigma } \\
\text { error }^{2}\end{array}$ & Concentration & $\begin{array}{c}1 \text { sigma } \\
\text { error }^{1}\end{array}$ & $\begin{array}{c}3 \text { sigma } \\
\text { error }^{2}\end{array}$ \\
\hline Stove 1 & Ash lip & 5 & ND & 31 & 93 & 66 & 10 & 30 & ND & 313 & 939 \\
\hline Stove 1 & Ash lip & 6 & $\mathrm{ND}$ & 35 & 105 & 83 & 11 & 33 & ND & 366 & 1,100 \\
\hline Stove 1 & Ash lip & 7 & ND & 32 & 96 & 69 & 10 & 30 & ND & 275 & 825 \\
\hline Stove 1 & Top & 8 & ND & 27 & 81 & 52 & 10 & 30 & ND & 290 & 870 \\
\hline Stove 1 & Top & 9 & $\mathrm{ND}$ & 36 & 108 & 65 & 10 & 30 & ND & 311 & 933 \\
\hline Stove 1 & Top & 10 & ND & 31 & 93 & 69 & 10 & 30 & ND & 307 & 921 \\
\hline Stove 2 & Ash lip & 11 & ND & 36 & 108 & 91 & 11 & 33 & ND & 345 & 1,040 \\
\hline Stove 2 & Ash lip & 12 & ND & 42 & 126 & 76 & 11 & 33 & ND & 396 & 1,190 \\
\hline Stove 2 & Ash lip & 13 & ND & 31 & 93 & 51 & 9 & 27 & ND & 248 & 744 \\
\hline Stove 2 & Top & 14 & ND & 35 & 105 & 84 & 11 & 33 & ND & 341 & 1,020 \\
\hline Stove 2 & Top & 15 & ND & 41 & 123 & 79 & 12 & 36 & ND & 350 & 1,050 \\
\hline Stove 2 & Top & 16 & ND & 35 & 105 & 85 & 10 & 30 & ND & 294 & 882 \\
\hline Stove 3 & Ash lip & 17 & ND & 34 & 102 & 104 & 12 & 36 & ND & 390 & 1,170 \\
\hline Stove 3 & Ash lip & 18 & ND & 41 & 123 & 102 & 13 & 39 & ND & 427 & 1,280 \\
\hline Stove 3 & Ash lip & 19 & $\mathrm{ND}$ & 37 & 111 & 76 & 11 & 33 & ND & 371 & 1,110 \\
\hline Stove 3 & Top & 20 & $\mathrm{ND}$ & 30 & 90 & 77 & 11 & 33 & ND & 358 & 1,070 \\
\hline Stove 3 & Top & 21 & ND & 30 & 90 & 79 & 11 & 33 & ND & 343 & 1,030 \\
\hline Stove 3 & Top & 22 & ND & 28 & 84 & 61 & 10 & 30 & ND & 339 & 1,020 \\
\hline Stove $4^{3}$ & Ash lip & 23 & ND & 42 & 126 & 92 & 12 & 36 & ND & 378 & 1,130 \\
\hline Stove $4^{3}$ & Ash lip & 24 & $\mathrm{ND}$ & 40 & 120 & 92 & 12 & 36 & ND & 374 & 1,120 \\
\hline Stove $4^{3}$ & Ash lip & 25 & ND & 40 & 120 & 100 & 13 & 39 & ND & 421 & 1,260 \\
\hline Stove $4^{3}$ & Top & 26 & ND & 35 & 105 & 88 & 11 & 33 & ND & 361 & 1,080 \\
\hline Stove $4^{3}$ & Top & 27 & ND & 35 & 105 & 79 & 11 & 33 & ND & 381 & 1,140 \\
\hline Stove $4^{3}$ & Top & 28 & ND & 30 & 90 & 68 & 10 & 30 & ND & 324 & 972 \\
\hline Stove 5 & Ash lip & 29 & $\mathrm{ND}$ & 29 & 87 & 61 & 10 & 30 & ND & 313 & 939 \\
\hline Stove 5 & Ash lip & 30 & ND & 30 & 90 & 74 & 10 & 30 & ND & 306 & 918 \\
\hline Stove 5 & Ash lip & 31 & ND & 26 & 78 & 50 & 10 & 30 & ND & 307 & 921 \\
\hline Stove 5 & Top & 32 & ND & 29 & 87 & 70 & 10 & 30 & ND & 319 & 957 \\
\hline Stove 5 & Top & 33 & ND & 30 & 90 & 94 & 11 & 33 & ND & 337 & 1,010 \\
\hline Stove 5 & Top & 34 & ND & 23 & 69 & 78 & 11 & 33 & ND & 323 & 969 \\
\hline Stove 6 & Ash lip & 36 & ND & 24 & 72 & 54 & 8 & 24 & ND & 156 & 468 \\
\hline Stove 6 & Ash lip & 37 & ND & 22 & 66 & 54 & 9 & 27 & ND & 191 & 573 \\
\hline Stove 6 & Ash lip & 38 & ND & 21 & 63 & 59 & 8 & 24 & ND & 185 & 555 \\
\hline Stove 6 & Top & 39 & ND & 26 & 78 & 52 & 9 & 27 & ND & 248 & 744 \\
\hline Stove 6 & Top & 40 & ND & 28 & 84 & 52 & 9 & 27 & ND & 271 & 813 \\
\hline Stove 6 & Top & 41 & ND & 29 & 87 & 65 & 10 & 30 & ND & 276 & 828 \\
\hline Stove 7 & Ash lip & 42 & ND & 33 & 99 & 77 & 11 & 33 & ND & 344 & 1,030 \\
\hline Stove 7 & Ash lip & 43 & ND & 30 & 90 & 76 & 11 & 33 & ND & 348 & 1,040 \\
\hline Stove 7 & Ash lip & 44 & $\mathrm{ND}$ & 39 & 117 & 91 & 12 & 36 & ND & 396 & 1,190 \\
\hline Stove 7 & Top & 45 & $\mathrm{ND}$ & 35 & 105 & 85 & 11 & 33 & ND & 332 & 996 \\
\hline Stove 7 & Top & 46 & $\mathrm{ND}$ & 37 & 111 & 101 & 13 & 39 & ND & 421 & 1,260 \\
\hline Stove 7 & Top & 47 & ND & 33 & 99 & 75 & 11 & 33 & ND & 334 & 1,000 \\
\hline Stove 8 & Ash lip & 48 & ND & 33 & 99 & 112 & 12 & 36 & ND & 330 & 990 \\
\hline Stove 8 & Ash lip & 49 & ND & 37 & 111 & 81 & 11 & 33 & ND & 328 & 984 \\
\hline Stove 8 & Ash lip & 50 & ND & 26 & 78 & 53 & 9 & 27 & ND & 289 & 867 \\
\hline Stove 8 & Top & 52 & $\mathrm{ND}$ & 28 & 84 & 37 & 9 & 27 & ND & 258 & 774 \\
\hline Stove 8 & Top & 53 & ND & 26 & 78 & 72 & 10 & 30 & ND & 270 & 810 \\
\hline Stove 8 & Top & 54 & ND & 27 & 81 & 66 & 10 & 30 & ND & 269 & 807 \\
\hline Stove 9 & Ash lip & 55 & ND & 33 & 99 & 83 & 11 & 33 & ND & 325 & 975 \\
\hline Stove 9 & Ash lip & 56 & ND & 30 & 90 & 71 & 10 & 30 & ND & 298 & 894 \\
\hline Stove 9 & Ash lip & 57 & ND & 30 & 90 & 80 & 11 & 33 & ND & 329 & 987 \\
\hline Stove 9 & Top & 58 & ND & 35 & 105 & 112 & 13 & 39 & ND & 403 & 1,210 \\
\hline Stove 9 & Top & 59 & ND & 31 & 93 & 58 & 10 & 30 & ND & 346 & 1,040 \\
\hline Stove 9 & Top & 60 & ND & 40 & 120 & 83 & 12 & 36 & ND & 389 & 1,170 \\
\hline Footed pot & Outside & 61 & ND & 57 & 171 & 108 & 18 & 54 & ND & 608 & 180 \\
\hline Footed pot & Outside & 62 & ND & 36 & 108 & 97 & 13 & 39 & ND & 430 & 1,290 \\
\hline Footed pot & Inside & 63 & ND & 40 & 120 & 74 & 11 & 33 & ND & 336 & 1,010 \\
\hline Footed pot & Inside & 64 & ND & 55 & 165 & 94 & 17 & 51 & ND & 461 & 1,380 \\
\hline Footed pot & Outside & 65 & ND & 38 & 114 & 69 & 11 & 33 & ND & 334 & 1,000 \\
\hline Footed pot & Outside & 66 & ND & 51 & 153 & 90 & 16 & 48 & ND & 547 & 1,640 \\
\hline Kettle & Outside & 67 & ND & 28 & 84 & 50 & 12 & 36 & ND & 348 & 1,040 \\
\hline Kettle & Outside & 68 & $\mathrm{ND}$ & 30 & 90 & 70 & 12 & 36 & ND & 349 & 1,050 \\
\hline Kettle & Outside & 69 & ND & 23 & 69 & 41 & 11 & 33 & ND & 334 & 1,000 \\
\hline
\end{tabular}


Table H. Results of analysis by X-ray fluorescence spectroscopy of cast iron artifacts in the Hopewell Furnace National Historic Site museum, Pennsylvania.-Continued

[Artifacts are shown on figure 9; analyses by Martin Helmke of West Chester University. All concentrations are in parts per million (ppm); E, estimated value below detection limit; ND, not detected; >, greater than]

\begin{tabular}{|c|c|c|c|c|c|c|c|c|c|c|c|}
\hline \multirow{2}{*}{$\begin{array}{l}\text { Artifact } \\
\text { number }\end{array}$} & \multirow{2}{*}{$\begin{array}{l}\text { Sample } \\
\text { location }\end{array}$} & \multirow{2}{*}{$\begin{array}{c}\text { Reading } \\
\text { number }\end{array}$} & \multicolumn{3}{|c|}{ Rubidium (ppm) } & \multicolumn{3}{|c|}{ Selenium (ppm) } & \multicolumn{3}{|c|}{ Silver (ppm) } \\
\hline & & & Concentration & $\begin{array}{c}1 \text { sigma } \\
\text { error }^{1}\end{array}$ & $\begin{array}{c}3 \text { sigma } \\
\text { error }^{2}\end{array}$ & Concentration & $\begin{array}{c}1 \text { sigma } \\
\text { error }^{1}\end{array}$ & $\begin{array}{c}3 \text { sigma } \\
\text { error }^{2}\end{array}$ & Concentration & $\begin{array}{c}1 \text { sigma } \\
\text { error }^{1}\end{array}$ & $\begin{array}{c}3 \text { sigma } \\
\text { error }^{2}\end{array}$ \\
\hline Stove 1 & Ash lip & 5 & ND & 16 & 48 & ND & 12 & 36 & $21 \mathrm{E}$ & 42 & 126 \\
\hline Stove 1 & Ash lip & 6 & 258 & 21 & 63 & ND & 13 & 39 & ND & 45 & 135 \\
\hline Stove 1 & Ash lip & 7 & ND & 14 & 42 & ND & 12 & 36 & $111 \mathrm{E}$ & 39 & 117 \\
\hline Stove 1 & Top & 8 & ND & 15 & 45 & ND & 11 & 33 & $17 \mathrm{E}$ & 39 & 117 \\
\hline Stove 1 & Top & 9 & ND & 15 & 45 & ND & 12 & 36 & $95 \mathrm{E}$ & 40 & 120 \\
\hline Stove 1 & Top & 10 & ND & 15 & 45 & ND & 13 & 39 & $105 \mathrm{E}$ & 40 & 120 \\
\hline Stove 2 & Ash lip & 11 & ND & 18 & 54 & ND & 14 & 42 & $86 \mathrm{E}$ & 45 & 135 \\
\hline Stove 2 & Ash lip & 12 & ND & 21 & 63 & ND & 15 & 45 & $98 \mathrm{E}$ & 47 & 141 \\
\hline Stove 2 & Ash lip & 13 & ND & 12 & 36 & $8 \mathrm{E}$ & 14 & 42 & $57 \mathrm{E}$ & 36 & 108 \\
\hline Stove 2 & Top & 14 & ND & 17 & 51 & ND & 15 & 45 & $109 \mathrm{E}$ & 43 & 129 \\
\hline Stove 2 & Top & 15 & ND & 18 & 54 & $9 \mathrm{E}$ & 19 & 57 & $31 \mathrm{E}$ & 48 & 144 \\
\hline Stove 2 & Top & 16 & ND & 14 & 42 & ND & 14 & 42 & $29 \mathrm{E}$ & 39 & 117 \\
\hline Stove 3 & Ash lip & 17 & ND & 22 & 66 & ND & 16 & 48 & $90 \mathrm{E}$ & 48 & 144 \\
\hline Stove 3 & Ash lip & 18 & ND & 23 & 69 & ND & 18 & 54 & $9 \mathrm{E}$ & 48 & 144 \\
\hline Stove 3 & Ash lip & 19 & ND & 19 & 57 & ND & 13 & 39 & ND & 44 & 132 \\
\hline Stove 3 & Top & 20 & ND & 19 & 57 & ND & 15 & 45 & $29 \mathrm{E}$ & 45 & 135 \\
\hline Stove 3 & Top & 21 & ND & 17 & 51 & ND & 12 & 36 & $12 \mathrm{E}$ & 44 & 132 \\
\hline Stove 3 & Top & 22 & ND & 17 & 51 & ND & 12 & 36 & $49 \mathrm{E}$ & 43 & 129 \\
\hline Stove $4^{3}$ & Ash lip & 23 & ND & 20 & 60 & $8 \mathrm{E}$ & 17 & 51 & $63 \mathrm{E}$ & 47 & 141 \\
\hline Stove $4^{3}$ & Ash lip & 24 & ND & 19 & 57 & ND & 16 & 48 & ND & 45 & 135 \\
\hline Stove $4^{3}$ & Ash lip & 25 & ND & 21 & 63 & ND & 16 & 48 & $58 \mathrm{E}$ & 49 & 147 \\
\hline Stove $4^{3}$ & Top & 26 & ND & 17 & 51 & ND & 13 & 39 & $42 \mathrm{E}$ & 44 & 132 \\
\hline Stove $4^{3}$ & Top & 27 & ND & 17 & 51 & ND & 12 & 36 & $86 \mathrm{E}$ & 43 & 129 \\
\hline Stove $4^{3}$ & Top & 28 & ND & 15 & 45 & ND & 11 & 33 & $90 \mathrm{E}$ & 41 & 123 \\
\hline Stove 5 & Ash lip & 29 & ND & 15 & 45 & ND & 11 & 33 & $1 \mathrm{E}$ & 39 & 117 \\
\hline Stove 5 & Ash lip & 30 & ND & 14 & 42 & ND & 11 & 33 & $35 \mathrm{E}$ & 41 & 123 \\
\hline Stove 5 & Ash lip & 31 & ND & 14 & 42 & ND & 9 & 27 & ND & 40 & 120 \\
\hline Stove 5 & Top & 32 & ND & 16 & 48 & ND & 13 & 39 & $34 \mathrm{E}$ & 39 & 117 \\
\hline Stove 5 & Top & 33 & ND & 15 & 45 & ND & 12 & 36 & ND & 42 & 126 \\
\hline Stove 5 & Top & 34 & ND & 14 & 42 & ND & 11 & 33 & $17 \mathrm{E}$ & 41 & 123 \\
\hline Stove 6 & Ash lip & 36 & 60 & 8 & 24 & ND & 9 & 27 & $45 \mathrm{E}$ & 30 & 90 \\
\hline Stove 6 & Ash lip & 37 & 40 & 8 & 24 & ND & 8 & 24 & $20 \mathrm{E}$ & 34 & 102 \\
\hline Stove 6 & Ash lip & 38 & ND & 9 & 27 & ND & 8 & 24 & $1 \mathrm{E}$ & 32 & 96 \\
\hline Stove 6 & Top & 39 & ND & 12 & 36 & ND & 9 & 27 & $27 \mathrm{E}$ & 36 & 108 \\
\hline Stove 6 & Top & 40 & ND & 13 & 39 & ND & 12 & 36 & ND & 38 & 114 \\
\hline Stove 6 & Top & 41 & ND & 13 & 39 & ND & 13 & 39 & $57 \mathrm{E}$ & 39 & 117 \\
\hline Stove 7 & Ash lip & 42 & ND & 17 & 51 & ND & 12 & 36 & $64 \mathrm{E}$ & 43 & 129 \\
\hline Stove 7 & Ash lip & 43 & ND & 18 & 54 & ND & 12 & 36 & $112 \mathrm{E}$ & 44 & 132 \\
\hline Stove 7 & Ash lip & 44 & ND & 20 & 60 & ND & 14 & 42 & $58 \mathrm{E}$ & 48 & 144 \\
\hline Stove 7 & Top & 45 & ND & 17 & 51 & ND & 13 & 39 & $30 \mathrm{E}$ & 42 & 126 \\
\hline Stove 7 & Top & 46 & ND & 22 & 66 & ND & 16 & 48 & $113 \mathrm{E}$ & 50 & 150 \\
\hline Stove 7 & Top & 47 & ND & 17 & 51 & ND & 12 & 36 & $13 \mathrm{E}$ & 43 & 129 \\
\hline Stove 8 & Ash lip & 48 & ND & 16 & 48 & ND & 13 & 39 & $21 \mathrm{E}$ & 43 & 129 \\
\hline Stove 8 & Ash lip & 49 & ND & 15 & 45 & ND & 12 & 36 & ND & 42 & 126 \\
\hline Stove 8 & Ash lip & 50 & ND & 14 & 42 & ND & 9 & 27 & ND & 39 & 117 \\
\hline Stove 8 & Top & 52 & ND & 12 & 36 & ND & 10 & 30 & $40 \mathrm{E}$ & 36 & 108 \\
\hline Stove 8 & Top & 53 & ND & 13 & 39 & ND & 8 & 24 & ND & 38 & 114 \\
\hline Stove 8 & Top & 54 & ND & 13 & 39 & ND & 10 & 30 & $97 \mathrm{E}$ & 37 & 111 \\
\hline Stove 9 & Ash lip & 55 & ND & 16 & 48 & ND & 12 & 36 & $87 \mathrm{E}$ & 43 & 129 \\
\hline Stove 9 & Ash lip & 56 & ND & 14 & 42 & ND & 12 & 36 & $56 \mathrm{E}$ & 40 & 120 \\
\hline Stove 9 & Ash lip & 57 & ND & 16 & 48 & ND & 12 & 36 & $110 \mathrm{E}$ & 43 & 129 \\
\hline Stove 9 & Top & 58 & ND & 20 & 60 & ND & 16 & 48 & $86 \mathrm{E}$ & 51 & 153 \\
\hline Stove 9 & Top & 59 & ND & 18 & 54 & ND & 12 & 36 & $64 \mathrm{E}$ & 42 & 126 \\
\hline Stove 9 & Top & 60 & ND & 21 & 63 & ND & 14 & 42 & $35 \mathrm{E}$ & 46 & 138 \\
\hline Footed pot & Outside & 61 & ND & 29 & 87 & ND & 25 & 75 & $10 \mathrm{E}$ & 69 & 207 \\
\hline Footed pot & Outside & 62 & ND & 21 & 63 & ND & 15 & 45 & $70 \mathrm{E}$ & 48 & 144 \\
\hline Footed pot & Inside & 63 & ND & 16 & 48 & ND & 17 & 51 & $99 \mathrm{E}$ & 44 & 132 \\
\hline Footed pot & Inside & 64 & ND & 19 & 57 & ND & 26 & 78 & ND & 64 & 192 \\
\hline Footed pot & Outside & 65 & ND & 15 & 45 & ND & 15 & 45 & $76 \mathrm{E}$ & 45 & 135 \\
\hline Footed pot & Outside & 66 & ND & 25 & 75 & $14 \mathrm{E}$ & 26 & 78 & $182 \mathrm{E}$ & 62 & 186 \\
\hline Kettle & Outside & 67 & $30 \mathrm{E}$ & 13 & 39 & ND & 9 & 27 & $25 \mathrm{E}$ & 48 & 144 \\
\hline Kettle & Outside & 68 & $29 \mathrm{E}$ & 13 & 39 & ND & 11 & 33 & $36 \mathrm{E}$ & 48 & 144 \\
\hline Kettle & Outside & 69 & $16 \mathrm{E}$ & 12 & 36 & ND & 11 & 33 & $58 \mathrm{E}$ & 45 & 135 \\
\hline
\end{tabular}


Table H. Results of analysis by X-ray fluorescence spectroscopy of cast iron artifacts in the Hopewell Furnace National Historic Site museum, Pennsylvania.-Continued

[Artifacts are shown on figure 9; analyses by Martin Helmke of West Chester University. All concentrations are in parts per million (ppm); E, estimated value below detection limit; ND, not detected; >, greater than]

\begin{tabular}{|c|c|c|c|c|c|c|c|c|c|c|c|}
\hline \multirow{2}{*}{$\begin{array}{l}\text { Artifact } \\
\text { number }\end{array}$} & \multirow{2}{*}{$\begin{array}{l}\text { Sample } \\
\text { location }\end{array}$} & \multirow{2}{*}{$\begin{array}{c}\text { Reading } \\
\text { number }\end{array}$} & \multicolumn{3}{|c|}{ Strontium (ppm) } & \multicolumn{3}{|c|}{ Tin (ppm) } & \multicolumn{3}{|c|}{ Titanium (ppm) } \\
\hline & & & Concentration & $\begin{array}{c}1 \text { sigma } \\
\text { error }^{1}\end{array}$ & $\begin{array}{c}3 \text { sigma } \\
\text { error }^{2}\end{array}$ & Concentration & $\begin{array}{c}1 \text { sigma } \\
\text { error }^{1}\end{array}$ & $\begin{array}{c}3 \text { sigma } \\
\text { error }^{2}\end{array}$ & Concentration & $\begin{array}{c}1 \text { sigma } \\
\text { error }^{1}\end{array}$ & $\begin{array}{c}3 \text { sigma } \\
\text { error }^{2}\end{array}$ \\
\hline $\begin{array}{l}\text { Stove } 1 \\
\text {. }\end{array}$ & Ash lip & 5 & 103 & 11 & 33 & ND & 81 & 243 & ND & 5,350 & 16,100 \\
\hline Stove 1 & Ash lip & 6 & 97 & 11 & 33 & $166 \mathrm{E}$ & 87 & 261 & ND & 6,070 & 18,200 \\
\hline Stove 1 & Ash lip & 7 & 90 & 10 & 30 & $9 \mathrm{E}$ & 76 & 228 & $12,400 \mathrm{E}$ & 4,720 & 14,100 \\
\hline Stove 1 & Top & 8 & 60 & 8 & 24 & $38 \mathrm{E}$ & 76 & 228 & ND & 4,860 & 14,600 \\
\hline Stove 1 & Top & 9 & 53 & 8 & 24 & $179 \mathrm{E}$ & 79 & 237 & ND & 5,180 & 15,500 \\
\hline Stove 1 & Top & 10 & 68 & 9 & 27 & ND & 78 & 234 & $5,860 \mathrm{E}$ & 5,190 & 15,600 \\
\hline Stove 2 & Ash lip & 11 & 96 & 11 & 33 & ND & 87 & 261 & ND & 5,620 & 16,900 \\
\hline Stove 2 & Ash lip & 12 & 95 & 12 & 36 & ND & 92 & 276 & ND & 6,580 & 19,700 \\
\hline Stove 2 & Ash lip & 13 & 79 & 9 & 27 & $18 \mathrm{E}$ & 68 & 204 & ND & 3,840 & 11,500 \\
\hline Stove 2 & Top & 14 & 54 & 9 & 27 & $173 \mathrm{E}$ & 85 & 255 & ND & 5,490 & 16,500 \\
\hline Stove 2 & Top & 15 & 58 & 10 & 30 & ND & 88 & 264 & ND & 5,790 & 17,400 \\
\hline Stove 2 & Top & 16 & 67 & 9 & 27 & $43 \mathrm{E}$ & 74 & 222 & ND & 4,420 & 13,300 \\
\hline Stove 3 & Ash lip & 17 & 44 & 9 & 27 & $60 \mathrm{E}$ & 91 & 273 & ND & 6,430 & 19,300 \\
\hline Stove 3 & Ash lip & 18 & 56 & 10 & 30 & ND & 98 & 294 & ND & 7,140 & 21,400 \\
\hline Stove 3 & Ash lip & 19 & 57 & 9 & 27 & $45 \mathrm{E}$ & 85 & 255 & $763 \mathrm{E}$ & 6,130 & 18,400 \\
\hline Stove 3 & Top & 20 & 67 & 9 & 27 & $84 \mathrm{E}$ & 88 & 264 & $905 \mathrm{E}$ & 6,050 & 18,200 \\
\hline Stove 3 & Top & 21 & 60 & 9 & 27 & $56 \mathrm{E}$ & 82 & 246 & ND & 5,580 & 16,800 \\
\hline Stove 3 & Top & 22 & 47 & 8 & 24 & $170 \mathrm{E}$ & 84 & 252 & ND & 5,640 & 16,900 \\
\hline Stove $4^{3}$ & Ash lip & 23 & 44 & 9 & 27 & ND & 90 & 270 & ND & 5,970 & 17,900 \\
\hline Stove $4^{3}$ & Ash lip & 24 & 42 & 8 & 24 & $60 \mathrm{E}$ & 89 & 267 & ND & 5,990 & 18,000 \\
\hline Stove $4^{3}$ & Ash lip & 25 & 47 & 9 & 27 & $116 \mathrm{E}$ & 94 & 282 & ND & 6,660 & 20,000 \\
\hline Stove $4^{3}$ & Top & 26 & 47 & 8 & 24 & $166 \mathrm{E}$ & 85 & 255 & $1,340 \mathrm{E}$ & 5,640 & 16,900 \\
\hline Stove $4^{3}$ & Top & 27 & 58 & 9 & 27 & $87 \mathrm{E}$ & 87 & 261 & ND & 5,640 & 16,900 \\
\hline Stove $4^{3}$ & Top & 28 & 54 & 8 & 24 & $4 \mathrm{E}$ & 78 & 234 & $118 \mathrm{E}$ & 5,030 & 15,100 \\
\hline Stove 5 & Ash lip & 29 & 30 & 7 & 21 & $31 \mathrm{E}$ & 78 & 234 & ND & 4,940 & 14,800 \\
\hline Stove 5 & Ash lip & 30 & 52 & 8 & 24 & ND & 80 & 240 & ND & 4,760 & 14,300 \\
\hline Stove 5 & Ash lip & 31 & 31 & 7 & 21 & ND & 78 & 234 & ND & 4,820 & 14,500 \\
\hline Stove 5 & Top & 32 & 41 & 7 & 21 & $79 \mathrm{E}$ & 80 & 240 & ND & 5,080 & 15,200 \\
\hline Stove 5 & Top & 33 & 41 & 8 & 24 & ND & 81 & 243 & ND & 5,300 & 15,900 \\
\hline Stove 5 & Top & 34 & 52 & 8 & 24 & $27 \mathrm{E}$ & 80 & 240 & ND & 4,910 & 14,700 \\
\hline Stove 6 & Ash lip & 36 & 233 & 12 & 36 & $43 \mathrm{E}$ & 58 & 174 & $210 \mathrm{E}$ & 2,520 & 7,560 \\
\hline Stove 6 & Ash lip & 37 & 128 & 10 & 30 & $5 \mathrm{E}$ & 66 & 198 & $798 \mathrm{E}$ & 3,110 & 9,340 \\
\hline Stove 6 & Ash lip & 38 & 72 & 7 & 21 & ND & 62 & 186 & $1,520 \mathrm{E}$ & 3,030 & 9,100 \\
\hline Stove 6 & Top & 39 & 44 & 7 & 21 & ND & 68 & 204 & ND & 3,990 & 12,000 \\
\hline Stove 6 & Top & 40 & 58 & 8 & 24 & $63 \mathrm{E}$ & 74 & 222 & ND & 4,330 & 13,000 \\
\hline Stove 6 & Top & 41 & 44 & 7 & 21 & $64 \mathrm{E}$ & 76 & 228 & ND & 4,310 & 12,900 \\
\hline Stove 7 & Ash lip & 42 & 67 & 9 & 27 & ND & 84 & 252 & ND & 5,550 & 16,700 \\
\hline Stove 7 & Ash lip & 43 & 107 & 11 & 33 & $8 \mathrm{E}$ & 87 & 261 & ND & 5,530 & 16,600 \\
\hline Stove 7 & Ash lip & 44 & 74 & 10 & 30 & $9 \mathrm{E}$ & 92 & 276 & ND & 6,380 & 19,100 \\
\hline Stove 7 & Top & 45 & 50 & 8 & 24 & $72 \mathrm{E}$ & 82 & 246 & ND & 5,470 & 16,400 \\
\hline Stove 7 & Top & 46 & 53 & 9 & 27 & $43 \mathrm{E}$ & 96 & 288 & ND & 6,960 & 20,900 \\
\hline Stove 7 & Top & 47 & 38 & 8 & 24 & $5 \mathrm{E}$ & 82 & 246 & ND & 5,420 & 16,300 \\
\hline Stove 8 & Ash lip & 48 & 102 & 11 & 33 & $17 \mathrm{E}$ & 84 & 252 & ND & 5,330 & 16,000 \\
\hline Stove 8 & Ash lip & 49 & 112 & 11 & 33 & $46 \mathrm{E}$ & 83 & 249 & ND & 5,320 & 16,000 \\
\hline Stove 8 & Ash lip & 50 & 50 & 8 & 24 & $87 \mathrm{E}$ & 77 & 231 & ND & 4,480 & 13,400 \\
\hline Stove 8 & Top & 52 & 110 & 10 & 30 & $32 \mathrm{E}$ & 70 & 210 & ND & 4,190 & 12,600 \\
\hline Stove 8 & Top & 53 & 82 & 9 & 27 & $1 \mathrm{E}$ & 72 & 216 & ND & 4,230 & 12,700 \\
\hline Stove 8 & Top & 54 & 69 & 8 & 24 & $70 \mathrm{E}$ & 72 & 216 & ND & 4,340 & 13,000 \\
\hline Stove 9 & Ash lip & 55 & 85 & 10 & 30 & $177 \mathrm{E}$ & 84 & 252 & $14,400 \mathrm{E}$ & 5,410 & 16,200 \\
\hline Stove 9 & Ash lip & 56 & 68 & 9 & 27 & $49 \mathrm{E}$ & 79 & 237 & $2,540 \mathrm{E}$ & 4,820 & 14,500 \\
\hline Stove 9 & Ash lip & 57 & 108 & 11 & 33 & $103 \mathrm{E}$ & 83 & 249 & ND & 5,340 & 16,000 \\
\hline Stove 9 & Top & 58 & 69 & 10 & 30 & $146 \mathrm{E}$ & 97 & 291 & ND & 6,480 & 19,400 \\
\hline Stove 9 & Top & 59 & 53 & 8 & 24 & ND & 81 & 243 & ND & 5,560 & 16,700 \\
\hline Stove 9 & Top & 60 & 51 & 9 & 27 & ND & 89 & 267 & ND & 6,280 & 18,800 \\
\hline Footed pot & Outside & 61 & 40 & 12 & 36 & $293 \mathrm{E}$ & 133 & 399 & ND & 9,460 & 28,400 \\
\hline Footed pot & Outside & 62 & 31 & 8 & 24 & $47 \mathrm{E}$ & 98 & 294 & ND & 6,730 & 20,200 \\
\hline Footed pot & Inside & 63 & 30 & 8 & 24 & $82 \mathrm{E}$ & 86 & 258 & ND & 5,300 & 15,900 \\
\hline Footed pot & Inside & 64 & $23 \mathrm{E}$ & 11 & 33 & ND & 124 & 372 & ND & 7,210 & 21,600 \\
\hline Footed pot & Outside & 65 & 28 & 8 & 24 & $13 \mathrm{E}$ & 85 & 255 & ND & 5,100 & 15,300 \\
\hline Footed pot & Outside & 66 & 41 & 11 & 33 & ND & 122 & 366 & ND & 8,350 & 25,100 \\
\hline Kettle & Outside & 67 & $18 \mathrm{E}$ & 7 & 21 & ND & 92 & 276 & ND & 5,720 & 17,200 \\
\hline Kettle & Outside & 68 & 45 & 9 & 27 & ND & 93 & 279 & ND & 5,480 & 16,400 \\
\hline Kettle & Outside & 69 & 33 & 8 & 24 & $56 \mathrm{E}$ & 89 & 267 & ND & 5,370 & 16,100 \\
\hline
\end{tabular}


Table H. Results of analysis by X-ray fluorescence spectroscopy of cast iron artifacts in the Hopewell Furnace National Historic Site museum, Pennsylvania.-Continued

[Artifacts are shown on figure 9; analyses by Martin Helmke of West Chester University. All concentrations are in parts per million (ppm); E, estimated value below detection limit; ND, not detected; >, greater than]

\begin{tabular}{|c|c|c|c|c|c|c|c|c|}
\hline \multirow[b]{2}{*}{$\begin{array}{l}\text { Artifact } \\
\text { number }\end{array}$} & \multirow{2}{*}{$\begin{array}{c}\text { Sample } \\
\text { location }\end{array}$} & \multirow{2}{*}{$\begin{array}{c}\text { Reading } \\
\text { number }\end{array}$} & \multicolumn{3}{|c|}{ Zinc (ppm) } & \multicolumn{3}{|c|}{ Zirconium (ppm) } \\
\hline & & & Concentration & $\begin{array}{c}1 \text { sigma } \\
\text { error }^{1}\end{array}$ & $\begin{array}{c}3 \text { sigma } \\
\text { error }^{2}\end{array}$ & Concentration & $\begin{array}{c}1 \text { sigma } \\
\text { error }^{1}\end{array}$ & $\begin{array}{c}3 \text { sigma } \\
\text { error }^{2}\end{array}$ \\
\hline Stove 1 & Ash lip & 5 & 675 & 67 & 201 & $21 \mathrm{E}$ & 8 & 24 \\
\hline Stove 1 & Ash lip & 6 & 495 & 65 & 195 & $20 \mathrm{E}$ & 9 & 27 \\
\hline Stove 1 & Ash lip & 7 & 1,010 & 75 & 225 & 26 & 8 & 24 \\
\hline Stove 1 & Top & 8 & 2,420 & 130 & 390 & 25 & 8 & 24 \\
\hline Stove 1 & Top & 9 & 4,850 & 222 & 666 & 29 & 8 & 24 \\
\hline Stove 1 & Top & 10 & 2,330 & 129 & 387 & 25 & 8 & 24 \\
\hline Stove 2 & Ash lip & 11 & 865 & 79 & 237 & 28 & 9 & 27 \\
\hline Stove 2 & Ash lip & 12 & 836 & 87 & 261 & $17 \mathrm{E}$ & 9 & 27 \\
\hline Stove 2 & Ash lip & 13 & 2,650 & 127 & 381 & 26 & 7 & 21 \\
\hline Stove 2 & Top & 14 & 1,260 & 96 & 288 & $21 \mathrm{E}$ & 8 & 24 \\
\hline Stove 2 & Top & 15 & 2,780 & 169 & 507 & 36 & 10 & 30 \\
\hline Stove 2 & Top & 16 & 912 & 73 & 219 & $19 \mathrm{E}$ & 8 & 24 \\
\hline Stove 3 & Ash lip & 17 & 887 & 90 & 270 & 29 & 9 & 27 \\
\hline Stove 3 & Ash lip & 18 & 320 & 71 & 213 & $9 \mathrm{E}$ & 9 & 27 \\
\hline Stove 3 & Ash lip & 19 & 656 & 77 & 231 & $10 \mathrm{E}$ & 8 & 24 \\
\hline Stove 3 & Top & 20 & 318 & 59 & 177 & 36 & 9 & 27 \\
\hline Stove 3 & Top & 21 & 467 & 62 & 186 & $19 \mathrm{E}$ & 8 & 24 \\
\hline Stove 3 & Top & 22 & 292 & 55 & 165 & $18 \mathrm{E}$ & 8 & 24 \\
\hline Stove $4^{3}$ & Ash lip & 23 & 1,500 & 108 & 324 & $18 \mathrm{E}$ & 8 & 24 \\
\hline Stove $4^{3}$ & Ash lip & 24 & 766 & 74 & 222 & $17 \mathrm{E}$ & 8 & 24 \\
\hline Stove $4^{3}$ & Ash lip & 25 & 1,140 & 97 & 291 & 27 & 9 & 27 \\
\hline Stove $4^{3}$ & Top & 26 & 676 & 67 & 201 & 33 & 8 & 24 \\
\hline Stove $4^{3}$ & Top & 27 & 612 & 65 & 195 & 35 & 9 & 27 \\
\hline Stove $4^{3}$ & Top & 28 & 461 & 53 & 159 & $21 \mathrm{E}$ & 8 & 24 \\
\hline Stove 5 & Ash lip & 29 & $120 \mathrm{E}$ & 41 & 123 & $13 \mathrm{E}$ & 7 & 21 \\
\hline Stove 5 & Ash lip & 30 & 583 & 61 & 183 & 24 & 8 & 24 \\
\hline Stove 5 & Ash lip & 31 & 248 & 46 & 138 & 27 & 8 & 24 \\
\hline Stove 5 & Top & 32 & 872 & 74 & 222 & $16 \mathrm{E}$ & 7 & 21 \\
\hline Stove 5 & Top & 33 & 850 & 75 & 225 & 40 & 8 & 24 \\
\hline Stove 5 & Top & 34 & 591 & 61 & 183 & 30 & 8 & 24 \\
\hline Stove 6 & Ash lip & 36 & 1,950 & 84 & 252 & 43 & 7 & 21 \\
\hline Stove 6 & Ash lip & 37 & 1,010 & 62 & 186 & 43 & 7 & 21 \\
\hline Stove 6 & Ash lip & 38 & 1,060 & 62 & 186 & 35 & 7 & 21 \\
\hline Stove 6 & Top & 39 & 832 & 61 & 183 & $20 \mathrm{E}$ & 7 & 21 \\
\hline Stove 6 & Top & 40 & 770 & 62 & 186 & 22 & 7 & 21 \\
\hline Stove 6 & Top & 41 & 519 & 53 & 159 & 32 & 8 & 24 \\
\hline Stove 7 & Ash lip & 42 & 826 & 78 & 234 & $21 \mathrm{E}$ & 8 & 24 \\
\hline Stove 7 & Ash lip & 43 & 650 & 70 & 210 & 41 & 9 & 27 \\
\hline Stove 7 & Ash lip & 44 & 812 & 85 & 255 & $17 \mathrm{E}$ & 9 & 27 \\
\hline Stove 7 & Top & 45 & 1,930 & 119 & 357 & $20 \mathrm{E}$ & 8 & 24 \\
\hline Stove 7 & Top & 46 & 1,110 & 98 & 294 & $25 \mathrm{E}$ & 9 & 27 \\
\hline Stove 7 & Top & 47 & 952 & 80 & 240 & $20 \mathrm{E}$ & 8 & 24 \\
\hline Stove 8 & Ash lip & 48 & 8,220 & 360 & 1,080 & 35 & 9 & 27 \\
\hline Stove 8 & Ash lip & 49 & 3,330 & 171 & 513 & 25 & 8 & 24 \\
\hline Stove 8 & Ash lip & 50 & 730 & 65 & 195 & $19 \mathrm{E}$ & 7 & 21 \\
\hline Stove 8 & Top & 52 & 2,360 & 119 & 357 & 35 & 8 & 24 \\
\hline Stove 8 & Top & 53 & 2,950 & 142 & 426 & $19 \mathrm{E}$ & 7 & 21 \\
\hline Stove 8 & Top & 54 & 1,480 & 93 & 279 & $18 \mathrm{E}$ & 7 & 21 \\
\hline Stove 9 & Ash lip & 55 & 478 & 58 & 174 & 47 & 9 & 27 \\
\hline Stove 9 & Ash lip & 56 & 592 & 60 & 180 & 46 & 9 & 27 \\
\hline Stove 9 & Ash lip & 57 & 376 & 54 & 162 & $16 \mathrm{E}$ & 8 & 24 \\
\hline Stove 9 & Top & 58 & 548 & 72 & 216 & 39 & 9 & 27 \\
\hline Stove 9 & Top & 59 & 366 & 56 & 168 & $15 \mathrm{E}$ & 8 & 24 \\
\hline Stove 9 & Top & 60 & 230 & 55 & 165 & 28 & 9 & 27 \\
\hline Footed pot & Outside & 61 & 674 & 105 & 315 & $34 \mathrm{E}$ & 13 & 39 \\
\hline Footed pot & Outside & 62 & 348 & 61 & 183 & $13 \mathrm{E}$ & 9 & 27 \\
\hline Footed pot & Inside & 63 & 1,530 & 105 & 315 & $22 \mathrm{E}$ & 9 & 27 \\
\hline Footed pot & Inside & 64 & 2,450 & 203 & 609 & 44 & 14 & 42 \\
\hline Footed pot & Outside & 65 & 1,250 & 93 & 279 & 28 & 9 & 27 \\
\hline Footed pot & Outside & 66 & 676 & 96 & 288 & $33 \mathrm{E}$ & 12 & 36 \\
\hline Kettle & Outside & 67 & 376 & 56 & 168 & $18 \mathrm{E}$ & 9 & 27 \\
\hline Kettle & Outside & 68 & 785 & 77 & 231 & $17 \mathrm{E}$ & 9 & 27 \\
\hline Kettle & Outside & 69 & 1,270 & 98 & 294 & $22 \mathrm{E}$ & 9 & 27 \\
\hline
\end{tabular}

${ }^{1}$ The 1 sigma error represents the uncertainty of each analysis.

${ }^{2}$ The 3 sigma error is the level of detection. Values less than the 3 sigma error are estimated.

${ }^{3}$ Stove cast at Rock Furnace in Lancaster County. 

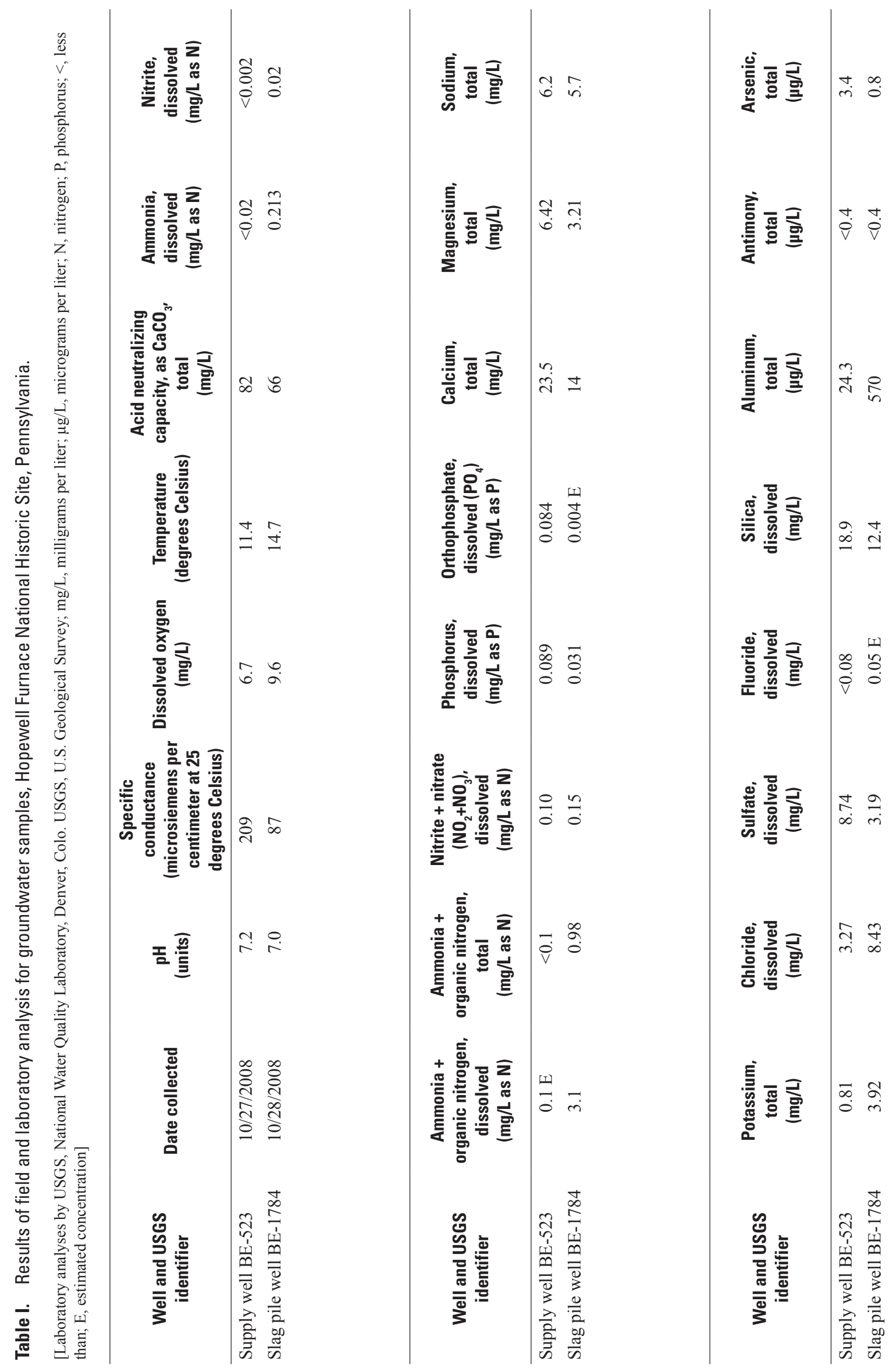


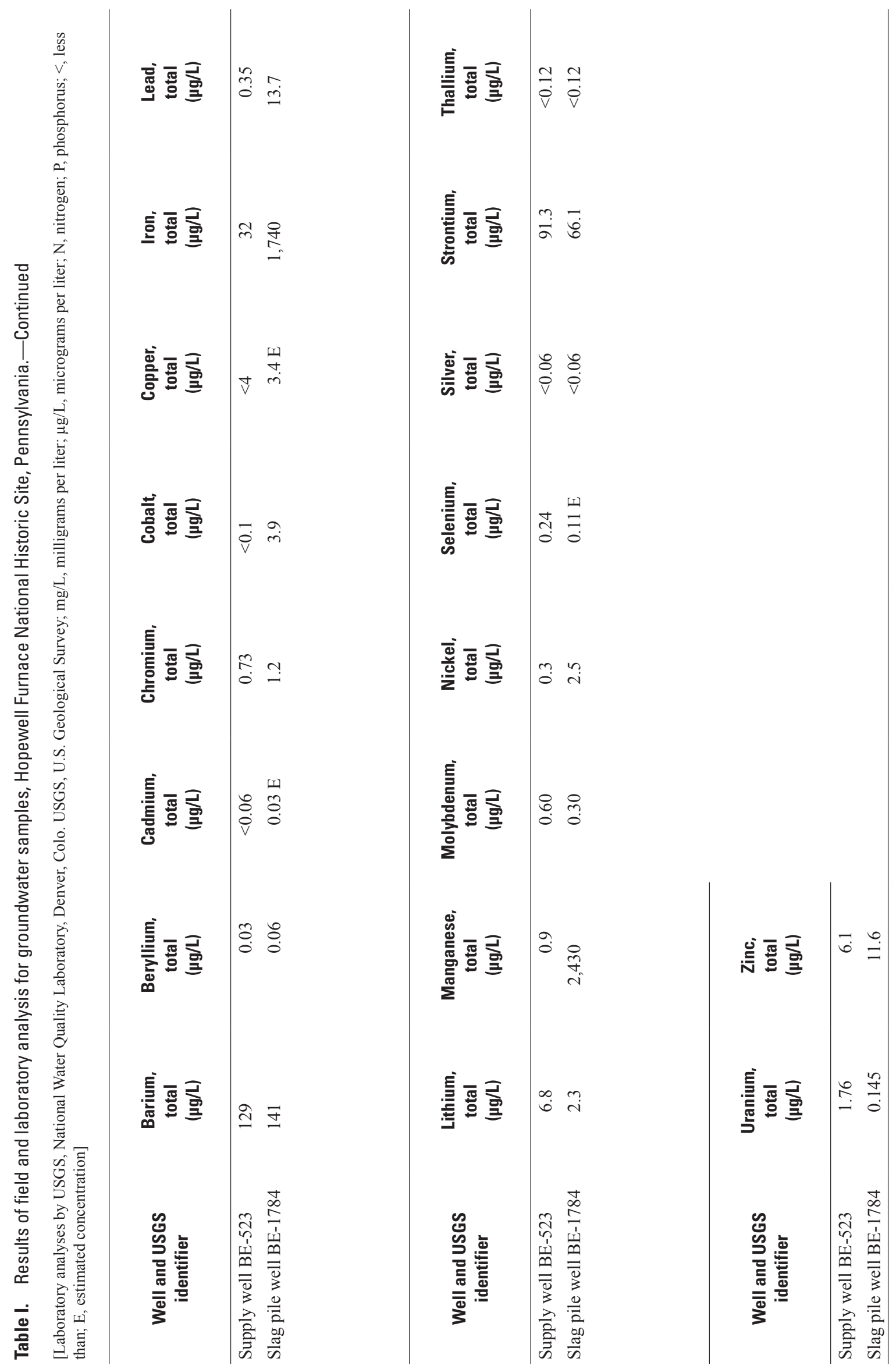



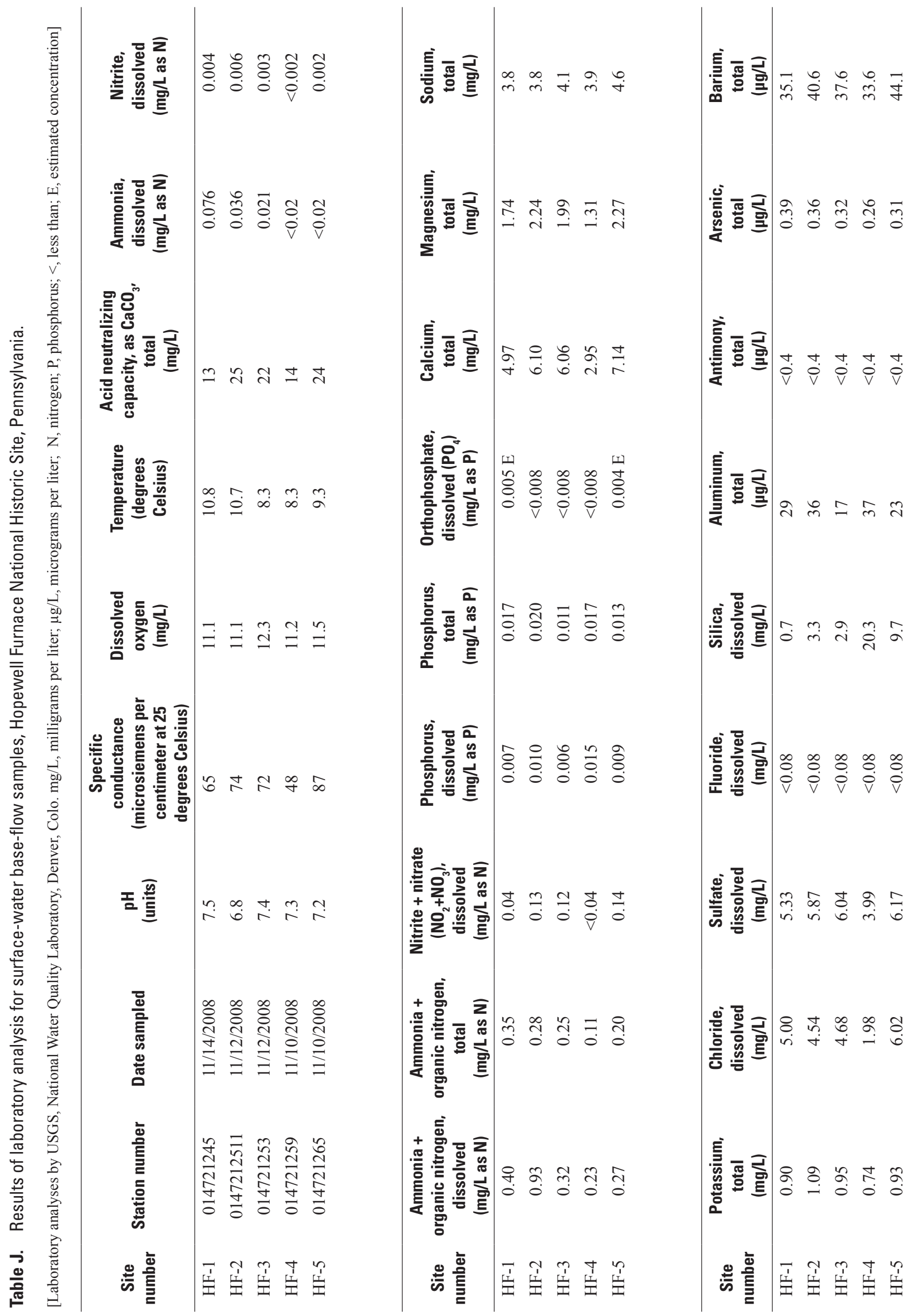


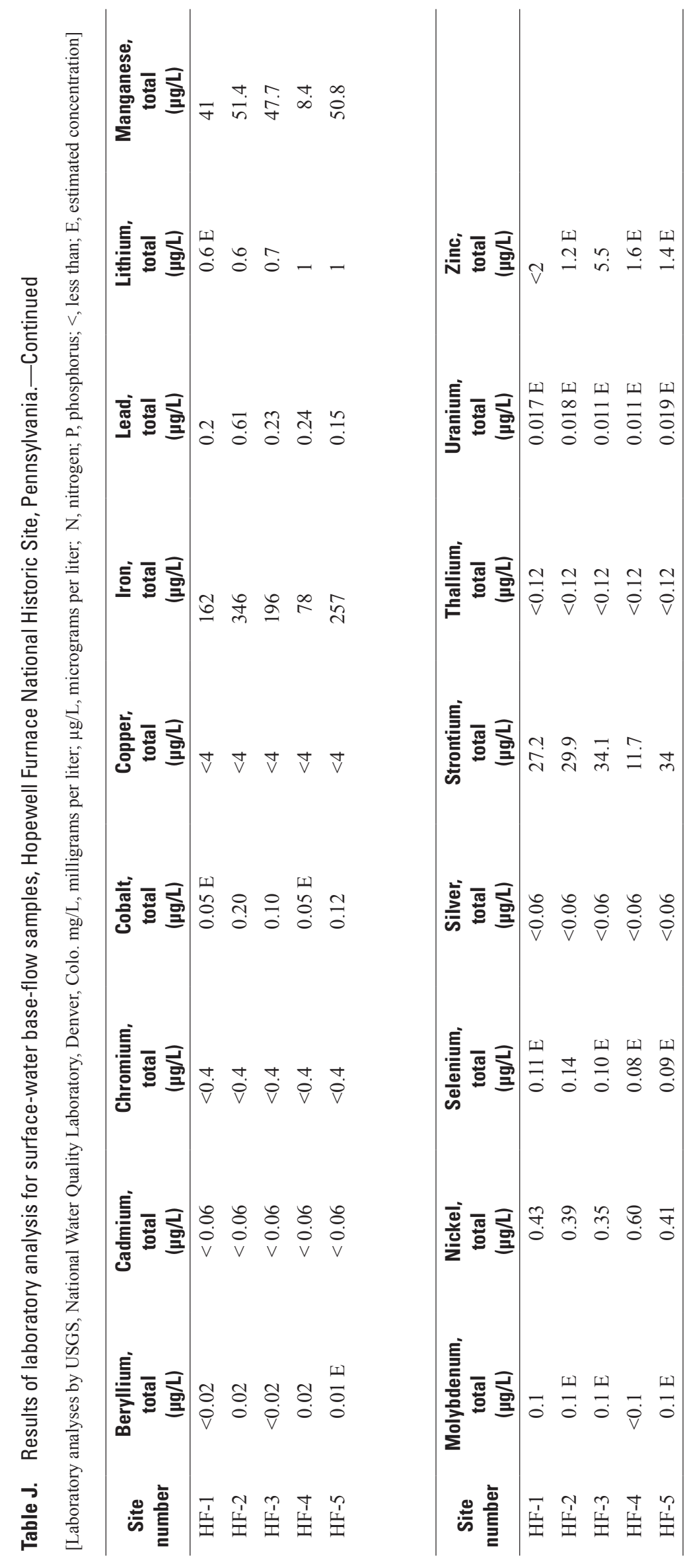


Table K. Benthic macroinvertebrates identified from 300 organism subsamples collected from sites at Hopewell Furnace National Historical Site, November 2008.

[Macroinvertebrate identication by Andrew G. Rief of the U.S. Geological Survey; PTV, Pollution tolerance value from Chalfant (2007)]

\begin{tabular}{|c|c|c|c|c|c|c|c|}
\hline Station number & & 014721245 & 0147212511 & 0147212511 & 014721253 & 014721259 & 014721265 \\
\hline Site number & & HF-1 & HF-2 & HF-2 replicate & $\mathrm{HF}-3$ & $\mathrm{HF}-4$ & $\mathrm{HF}-5$ \\
\hline Date sampled & & $11 / 14 / 08$ & $11 / 12 / 08$ & $11 / 12 / 08$ & $11 / 12 / 08$ & $11 / 10 / 08$ & $11 / 10 / 08$ \\
\hline Total count & & 317 & 336 & 302 & 302 & 330 & 93 \\
\hline Organism & PTV & \multicolumn{6}{|c|}{ Count } \\
\hline \multicolumn{8}{|l|}{ Turbellaria (flatworms) } \\
\hline \multicolumn{8}{|l|}{ Tricladida } \\
\hline Planariidae & 9 & 4 & & 1 & & & \\
\hline \multicolumn{8}{|l|}{ Nemertea (probosas worms) } \\
\hline \multicolumn{8}{|l|}{ Enopla } \\
\hline Prostoma & 6 & 3 & & & 1 & & \\
\hline \multicolumn{8}{|l|}{ Mollusca } \\
\hline \multicolumn{8}{|l|}{ Gastropoda (snails) } \\
\hline \multicolumn{8}{|l|}{ Basommatophora } \\
\hline \multicolumn{8}{|l|}{ Planorbidae } \\
\hline Planorbella & 6 & & & 1 & & & \\
\hline \multicolumn{8}{|l|}{ Neotaenioglaas } \\
\hline \multicolumn{8}{|l|}{ Hydrobiidae } \\
\hline Amnicola & 8 & & 3 & 2 & & & \\
\hline Pisidium & 8 & & & 1 & & & \\
\hline Sphaerium & 8 & & 4 & 1 & 2 & & \\
\hline \multicolumn{8}{|l|}{ Annelida (segmented worms) } \\
\hline \multicolumn{8}{|l|}{ Clitellata } \\
\hline \multicolumn{8}{|l|}{ Oligochaeta } \\
\hline \multicolumn{8}{|l|}{ Lumbriculida } \\
\hline Lumbriculidae & 8 & 3 & 18 & 25 & 8 & & \\
\hline \multicolumn{8}{|l|}{ Haplotaxida } \\
\hline Enchytraeidae & 10 & & & 1 & & & \\
\hline Naididae & 8 & 4 & 8 & 2 & 3 & & 9 \\
\hline \multicolumn{8}{|l|}{ Arthropoda } \\
\hline \multicolumn{8}{|l|}{ Arachnida } \\
\hline Acariformes (water mites) & 7 & 1 & 1 & & 5 & 4 & 3 \\
\hline
\end{tabular}


Table K. Benthic macroinvertebrates identified from 300 organism subsamples collected from sites at Hopewell Furnace National Historical Site, November 2008.-Continued

[Macroinvertebrate identication by Andrew G. Rief of the U.S. Geological Survey; PTV, Pollution tolerance value from Chalfant (2007)]

\begin{tabular}{|c|c|c|c|c|c|c|c|}
\hline Station number & & 014721245 & 0147212511 & 0147212511 & 014721253 & 014721259 & 014721265 \\
\hline Site number & & HF-1 & HF-2 & HF-2 replicate & HF-3 & $\mathrm{HF}-4$ & $\mathrm{HF}-5$ \\
\hline Date sampled & & $11 / 14 / 08$ & $11 / 12 / 08$ & $11 / 12 / 08$ & $11 / 12 / 08$ & $11 / 10 / 08$ & $11 / 10 / 08$ \\
\hline Total count & & 317 & 336 & 302 & 302 & 330 & 93 \\
\hline Organism & PTV & \multicolumn{6}{|c|}{ Count } \\
\hline \multicolumn{8}{|l|}{ Cladocera } \\
\hline \multicolumn{8}{|l|}{ Daphniidae } \\
\hline Daphnia & 5 & & 1 & 2 & & & \\
\hline \multicolumn{8}{|l|}{ Copepoda } \\
\hline \multicolumn{8}{|l|}{ Cyclopoida } \\
\hline \multicolumn{8}{|l|}{ Crangonyctidae } \\
\hline Crangonyx & 4 & 1 & 2 & 4 & 1 & & \\
\hline \multicolumn{8}{|l|}{ Talitridae } \\
\hline Hyalella & 8 & & 4 & 1 & & & \\
\hline \multicolumn{8}{|l|}{ Isopoda (sow bugs) } \\
\hline \multicolumn{8}{|l|}{ Asellidae } \\
\hline Caecidotea & 6 & & & & & & 1 \\
\hline Podocopa (seed shrimp) & 8 & & 3 & & & & \\
\hline \multicolumn{8}{|l|}{ Insecta } \\
\hline \multicolumn{8}{|l|}{ Ephemeroptera (mayflies) } \\
\hline \multicolumn{8}{|l|}{ Ephemerellidae } \\
\hline Eurylophella & 4 & 1 & 1 & & 9 & 1 & \\
\hline Serratella & 2 & & & 1 & 1 & 79 & 3 \\
\hline \multicolumn{8}{|l|}{ Heptageniidae } \\
\hline Epeorus & 0 & & & & & 1 & \\
\hline Stenacron & 4 & 1 & 1 & & & & \\
\hline Stenonema (Maccaffertium) & 3 & 64 & 29 & 12 & 33 & 28 & 12 \\
\hline \multicolumn{8}{|l|}{ Leptophlebiidae } \\
\hline Paraleptophlebia & 1 & & & 1 & & 1 & \\
\hline \multicolumn{8}{|c|}{ Odonata (dragonflies and damselflies) } \\
\hline \multicolumn{8}{|l|}{ Aeshnidae } \\
\hline Boyeria & 2 & & & & & & 1 \\
\hline Coenagrionidae & & & & & & & \\
\hline
\end{tabular}


Table K. Benthic macroinvertebrates identified from 300 organism subsamples collected from sites at Hopewell Furnace National Historical Site, November 2008.-Continued

[Macroinvertebrate identication by Andrew G. Rief of the U.S. Geological Survey; PTV, Pollution tolerance value from Chalfant (2007)]

\begin{tabular}{|c|c|c|c|c|c|c|c|}
\hline Station number & & 014721245 & 0147212511 & 0147212511 & 014721253 & 014721259 & 014721265 \\
\hline Site number & & HF-1 & HF-2 & HF-2 replicate & HF-3 & HF-4 & HF-5 \\
\hline Date sampled & & $11 / 14 / 08$ & $11 / 12 / 08$ & $11 / 12 / 08$ & $11 / 12 / 08$ & $11 / 10 / 08$ & $11 / 10 / 08$ \\
\hline Total count & & 317 & 336 & 302 & 302 & 330 & 93 \\
\hline Organism & PTV & \multicolumn{6}{|c|}{ Count } \\
\hline \multicolumn{8}{|l|}{ Gomphidae } \\
\hline Arigomphus & 4 & & 1 & & & & \\
\hline Gomphus & 5 & & 1 & 2 & & & \\
\hline Lanthus & 5 & & & & & 1 & \\
\hline \multicolumn{8}{|l|}{ Plecoptera (stoneflies) } \\
\hline Chloroperlidae & 0 & & & 1 & & & \\
\hline \multicolumn{8}{|l|}{ Peltoperlidae } \\
\hline Peltoperla & 2 & & & & & 2 & \\
\hline Nemouridae & 2 & & & & 2 & 2 & 1 \\
\hline \multicolumn{8}{|l|}{ Perlidae } \\
\hline Perlesta & 4 & & & & & 1 & \\
\hline \multicolumn{8}{|l|}{ Taeniopterygidae } \\
\hline Strophopteryx & 3 & & & & 1 & 5 & \\
\hline Taeniopteryx & 2 & & & & 2 & 3 & 2 \\
\hline \multicolumn{8}{|l|}{ Glossosomatidae } \\
\hline Glossosoma & 0 & & & & & 12 & \\
\hline \multicolumn{8}{|l|}{ Hydropsychidae } \\
\hline Cheumatopsyche & 6 & 179 & 25 & 24 & 35 & 27 & 20 \\
\hline Hydropsyche & 5 & 6 & 21 & 13 & 8 & 3 & \\
\hline \multicolumn{8}{|l|}{ Hydroptilidae } \\
\hline Hydroptila & 6 & 1 & & & & & 1 \\
\hline \multicolumn{8}{|l|}{ Lepidostomatidae } \\
\hline Lepidostoma & 1 & & & & & 2 & \\
\hline \multicolumn{8}{|l|}{ Leptoceridae } \\
\hline Oecetis & 8 & & 2 & 3 & & & \\
\hline \multicolumn{8}{|l|}{ Philopotamidae } \\
\hline Chimarra & 4 & & & & 3 & 1 & \\
\hline
\end{tabular}


Table K. Benthic macroinvertebrates identified from 300 organism subsamples collected from sites at Hopewell Furnace National Historical Site, November 2008. - Continued

[Macroinvertebrate identication by Andrew G. Rief of the U.S. Geological Survey; PTV, Pollution tolerance value from Chalfant (2007)]

\begin{tabular}{|c|c|c|c|c|c|c|c|}
\hline Station number & & 014721245 & 0147212511 & 0147212511 & 014721253 & 014721259 & 014721265 \\
\hline Site number & & HF-1 & $\mathrm{HF}-2$ & $\mathrm{HF}-2$ replicate & $\mathrm{HF}-3$ & $\mathrm{HF}-4$ & $\mathrm{HF}-5$ \\
\hline Date sampled & & $11 / 14 / 08$ & $11 / 12 / 08$ & $11 / 12 / 08$ & $11 / 12 / 08$ & $11 / 10 / 08$ & $11 / 10 / 08$ \\
\hline Grids & & 8 & 9 & 10 & 10 & 12 & 28 \\
\hline Total count & & 317 & 336 & 302 & 302 & 330 & 93 \\
\hline Organism & PTV & \multicolumn{6}{|c|}{ Count } \\
\hline \multicolumn{8}{|l|}{ Psychomyiidae } \\
\hline Lype & 2 & & & & & 1 & \\
\hline \multicolumn{8}{|l|}{ Rhyacophilidae } \\
\hline Rhyacophila & 1 & & & & & 2 & \\
\hline \multicolumn{8}{|l|}{ Uenoidae } \\
\hline Neophylax & 3 & & & & & 5 & \\
\hline \multicolumn{8}{|l|}{ Coleoptera (beetles) } \\
\hline \multicolumn{8}{|l|}{ Elmidae (riffle beetles) } \\
\hline Ancyronyx & 2 & & & & & & 1 \\
\hline Dubiraphia & 6 & & & 1 & & & 1 \\
\hline Optioservus & 4 & 1 & 1 & 1 & 3 & 3 & 2 \\
\hline Oulimnius & 5 & & & & & 24 & \\
\hline Promoresia & 2 & & & & 1 & 4 & 3 \\
\hline Stenelmis & 5 & & & & & 2 & \\
\hline \multicolumn{8}{|c|}{ Psephenidae (water pennies) } \\
\hline Ectopria & 5 & & & & & 1 & \\
\hline \multicolumn{8}{|l|}{ Diptera (true flies) } \\
\hline \multicolumn{8}{|l|}{ Ceratopogonidae } \\
\hline Probezzia & 6 & & 2 & 1 & 1 & 1 & 1 \\
\hline Chironomidae (midges) & 6 & 19 & 178 & 173 & 142 & 102 & 26 \\
\hline \multicolumn{8}{|l|}{ Empididae (dance flies) } \\
\hline Chelifera & 6 & & & & 5 & & \\
\hline Hemerodromia & 6 & 2 & 17 & 15 & 17 & & 2 \\
\hline \multicolumn{8}{|l|}{ Simuliidae (black flies) } \\
\hline Simulium & 6 & 5 & 3 & 2 & 9 & 2 & \\
\hline \multicolumn{8}{|l|}{ Tipulidae (crane flies) } \\
\hline Antocha & 3 & 2 & 1 & & & 1 & \\
\hline Diranota & 3 & & & & & 2 & \\
\hline Hexatoma & 2 & & & & & 1 & \\
\hline Tipula & 4 & 1 & & 1 & & & \\
\hline
\end{tabular}



For more information about this publication, contact: U.S. Geological Survey

215 Limekiln Road

New Cumberland, PA 17070

http://pa.water.usgs.gov/ 
